\title{
TSPO imaging in animal models of brain diseases
}

\author{
Nadja Van Camp ${ }^{1}$ (D) $\cdot$ Sonia Lavisse ${ }^{1}$ (D) $\cdot$ Pauline Roost $^{1} \cdot$ Francesco Gubinelli $^{1} \cdot$ Ansel Hillmer ${ }^{2,3,4}$ (D) \\ Hervé Boutin ${ }^{5,6,7}$
}

Received: 1 March 2021 / Accepted: 25 April 2021 / Published online: 10 July 2021

(C) The Author(s) 2021

\begin{abstract}
Over the last 30 years, the $18-\mathrm{kDa}$ TSPO protein has been considered as the PET imaging biomarker of reference to measure increased neuroinflammation. Generally assumed to image activated microglia, TSPO has also been detected in endothelial cells and activated astrocytes. Here, we provide an exhaustive overview of the recent literature on the TSPO-PET imaging (i) in the search and development of new TSPO tracers and (ii) in the understanding of acute and chronic neuroinflammation in animal models of neurological disorders. Generally, studies testing new TSPO radiotracers against the prototypic $\left[{ }^{11} \mathrm{C}\right]-\mathrm{R}-\mathrm{PK} 11195$ or more recent competitors use models of acute focal neuroinflammation (e.g. stroke or lipopolysaccharide injection). These studies have led to the development of over 60 new tracers during the last 15 years. These studies highlighted that interpretation of TSPO-PET is easier in acute models of focal lesions, whereas in chronic models with lower or diffuse microglial activation, such as models of Alzheimer's disease or Parkinson's disease, TSPO quantification for detection of neuroinflammation is more challenging, mirroring what is observed in clinic. Moreover, technical limitations of preclinical scanners provide a drawback when studying modest neuroinflammation in small brains (e.g. in mice). Overall, this review underlines the value of TSPO imaging to study the time course or response to treatment of neuroinflammation in acute or chronic models of diseases. As such, TSPO remains the gold standard biomarker reference for neuroinflammation, waiting for new radioligands for other, more specific targets for neuroinflammatory processes and/or immune cells to emerge.
\end{abstract}

Keywords Translocator protein $18 \mathrm{kDa} \cdot$ Neuroinflammation $\cdot$ Alzheimer's disease $\cdot$ Parkinson's disease $\cdot$ Stroke $\cdot$ Multiple sclerosis $\cdot$ Positron emission tomography

This article is part of the Topical Collection on Preclinical Imaging.

Hervé Boutin

herve.boutin@manchester.ac.uk

1 Université Paris-Saclay, CEA, CNRS, MIRCen, Laboratoire des Maladies Neurodégénératives, 92265 Fontenay-aux-Roses, France

2 Department of Psychiatry, Yale School of Medicine, New Haven, CT, USA

3 Department of Radiology \& Biomedical Imaging, Yale School of Medicine, New Haven, CT, USA

4 Department of Biomedical Engineering, Yale School of Engineering \& Applied Science, New Haven, CT, USA

5 Division of Neuroscience and Experimental Psychology, School of Biological Sciences, Faculty of Brain and Mental Health, University of Manchester, M13 9PL, Manchester, UK

6 Wolfson Molecular Imaging Centre, University of Manchester, 27 Palatine Road, M20 3LJ Manchester, UK

7 Geoffrey Jefferson Brain Research Centre, Manchester Academic Health Science Centre, Northern Care Alliance \& University of Manchester, Manchester, UK

\section{General introduction}

Nowadays, the $18-\mathrm{kDa}$ translocator protein (18-kDa TSPO) is the most prominent biomarker for imaging of glial activation and has been reviewed more than a hundred times over the last two decades (cf. PubMed search terms: "(omega* OR TSPO OR PBR OR PK11195) AND (PET OR positron) AND (brain OR cereb*) AND (English[ lang])" and selecting "review" or "systematic review"). About 40 years ago, this protein was named peripheral benzodiazepine receptors (or omega-3 binding site) due to its pharmacology (high affinity for some benzodiazepines) and its preferential expression in the myocardium, kidney and adrenals [1-3]. Its overexpression in brain lesions rapidly identified this protein as a potential in vivo imaging marker of inflammation-related neurodegeneration, notably in models of brain ischaemia [4-8]. One of the first applications of TSPO/PBR radioligands for positron emission tomography (PET) imaging was to image brain tumours in man $[9,10]$. It was only in the mid- to late 1990 s, 
using animal models of brain diseases that an increased level of TSPO/PBR was proven to be associated with microglial activation [11-14]. Preclinical models are of great utility when it comes to testing, validating and implementing new biomarkers, imaging methods and contrast agents. The preclinical contribution in the development of new radioligands for TSPO here is no exception, as underlined by its representation in the literature - more than a third of the abovementioned reviews.

Our aim here is to provide an exhaustive overview of the recent literature on the use of animal models in two major applications in the field of preclinical TSPO-PET imaging: either as a tool to develop new tracers and/or imaging methodologies or as a model to understand the contribution of acute and chronic neuroinflammation in neurological disorder models.

\section{Models of acute neuroinflammation}

\section{Tracer development}

The animal models of acute neuroinflammation described below have mostly been used for the development and validation of TSPO tracers as they provide generally a consistent, robust and focal neuroinflammatory response and TSPO expression with a well-described time course. From a tracer development perspective, on top of classical brain tracer characteristics such as high blood-brain barrier penetrance, neuroinflammation and TSPO tracers have specific highly desirable characteristics that are summarized in Table 1.

$P$-gp, P-glycoprotein; N/A, not applicable

\section{Lipopolysaccharide (LPS) model}

LPS, also referred to as endotoxin, is a major component of the outer membrane of gram-negative bacteria, with lipid A in the membrane and the $\mathrm{O}$ antigen constituting the outer-facing surface of the bacterium. Soluble endotoxin is released when bacteria are destroyed but is also released physiologically as outer membrane vesicles [15]. LPS is a potent inducer of inflammation both in peripheral tissues and in the central nervous system via the activation of toll-like receptor 4 (TLR4), which results in NF- $\mathrm{KB}$ transcriptional activation of hundreds of inflammatory genes, including pro-inflammatory cytokines such as TNF $\alpha$, IL-6 and pro-IL-1 $\beta$. LPS administration in preclinical models is performed systematically (intravenous, i.v., or intraperitoneal, i.p.) or by stereotactic intracerebral injection. In this topic, we will discuss TSPO-PET imaging studies in models using both administration routes. We used the following search in PubMed, "(omega* OR TSPO OR PBR OR PK11195) AND (PET OR positron) AND (brain OR cereb*) AND (LPS OR lipopolysaccharide) AND (rat OR mouse OR mice OR animal* OR experimental OR pig OR gerbil OR rabbit OR guinea OR primate OR dog OR cat) AND (English[ lang])", which returned initially 27 records. After exclusion of those that were not PET imaging studies that used LPS as a comorbidity factor and those not using LPS as a model per se, 18 references were retained to TSPO-PET imaging in LPS models.

It has been a matter of discussion how peripherally administered LPS induces neuroinflammation in the central nervous system. Initially, it was suggested that LPS-induced neuroinflammation was an indirect effect through $\mathrm{TNF} \alpha$, which crosses the blood-brain barrier [16]. However, it has been shown more recently that LPS infiltrates the brain via lipoprotein receptor (such as SR-B1) transport in which LPS binds specifically to those receptors at the blood-brain interfaces [17]. These receptors are located in astrocytes (as part of immunologic functional barriers), tanycytes that are in direct contact with the cerebrospinal fluid along the ventricular walls and centrum ventricular organs) and endothelial cells (arbitrating a neuroimmune communication by actively responding to immune challenges such as LPS through the release of cytokines and other mechanisms) [17]. Cytokine production and direct interaction of LPS with TLR4 induce microglial activation, the first-line defence of the brain. Using adult mice receiving a single intraperitoneal administration of LPS $(1 \mathrm{mg} / \mathrm{kg})$, it has been demonstrated by in vitro immunohistochemical studies
Table 1 Required characteristics for new neuroinflammation and TSPO tracers

\begin{tabular}{|c|c|}
\hline Challenges for new neuroinflammation tracers & Specific requirements for new TSPO tracers \\
\hline \multicolumn{2}{|l|}{ High metabolic stability } \\
\hline \multicolumn{2}{|c|}{ High free ligand availability in plasma (i.e., low binding to circulating cells or proteins) } \\
\hline \multicolumn{2}{|c|}{ High brain availability (i.e., high blood-brain barrier penetrance, not $P$-gp substrate) } \\
\hline $\mathrm{N} / \mathrm{A}$ & $\begin{array}{l}\text { No sensitivity to the TSPO rs } 6971 \\
\text { polymorphism }\end{array}$ \\
\hline Development of cell-specific ligands: microglia vs astrocytes & N/A \\
\hline $\begin{array}{l}\text { Neuroinflammatory phenotypic selectivity: pro- vs } \\
\text { anti-inflammatory }\end{array}$ & N/A \\
\hline
\end{tabular}


that microglial proliferation occurs nonuniformly in the central nervous system but in a region- and dose-dependent manner. This is followed by a return to control levels 20 days after a single stimulation independent of the LPS dose $(100 \mu \mathrm{g} / \mathrm{kg}$ or $1 \mathrm{mg} / \mathrm{kg}$ LPS) [18]. Altogether, various studies confirm that acute systemic LPS administration induces transient inflammation in the central nervous system [19, 20, 15], which makes LPS an appealing approach to measure the "neuroimmune response" by imaging TSPO levels. Moreover, at a low dose, the pro-inflammatory properties of endotoxin mimic the complex responses to systemic infection. However, due to the transient effect of acute endotoxin, consistent timing of imaging is required to ensure consistent results. Ota et al. were the first to image the neuroinflammatory response after a systematic LPS administration in the rat brain $\left(2 \mathrm{mg} / \mathrm{kg}\right.$, i.p.) using $\left[{ }^{11} \mathrm{C}\right]-\mathrm{R}-\mathrm{PK} 11195$ [21]. Animals were scanned before and 2 days after LPS administration, and the difference in SUV uptake was estimated with voxel-wise statistical parametric mapping. This revealed a striato-cortical cluster, which surprisingly reflected a significant decrease of the TSPO-PET signal rather than an increase. As this result was not further supported by any ex vivo or in vitro data, additionally considering both the limitations of the SUV measure in the absence of any blood data and the low specificity of $\left[{ }^{11} \mathrm{C}\right]-\mathrm{R}-\mathrm{PK} 11195$, interpretation of these data needs to be considered cautiously. A far more complete study in the rat brain was performed by Schmidt et al., who evaluated the time and regional course of the $\left[{ }^{11} \mathrm{C}\right]$ PBR28 TSPO-PET signal after a systemic (i.p.) LPS challenge $(3 \mathrm{mg} / \mathrm{kg})$ in the context of a genetic risk factor for Parkinson's disease (more details in the paragraph "Parkinson's disease" below) [22]. This study reported a reliable and consistent neuroinflammatory response $24 \mathrm{~h}$ after the challenge as visualized by in vitro autoradiography using $\left[{ }^{11} \mathrm{C}\right] \mathrm{PBR} 28$. Subsequently, a longitudinal in vivo $\left[{ }^{11} \mathrm{C}\right]$ PBR28 PET study demonstrated a significant detectable LPS-induced TSPO-PET response 10 months after administration, particularly in the cortical and ventral regions. As such, TSPO response to peripheral inflammation can also be monitored in an ethically viable manner by minimizing pathogenic risk to human subjects, providing an important model for studying immune signalling in human research [23]. TSPO imaging can leverage this model by conducting scans before and after endotoxin challenge, to measure the change in TSPO brain levels. The results provide important information on the brain's immune response to a stimulus, or immune function, to complement the snapshots of the brain's neuroimmune state assessed by single baseline TSPO scans. Such endotoxin protocol was first applied to non-human primates (baboons), where serial $\left[{ }^{11} \mathrm{C}\right]$ PBR28 images were acquired after i.v. administration of $0.1-\mathrm{mg} / \mathrm{kg}$ endotoxin [24]. This dose increased the $\left[{ }^{11} \mathrm{C}\right]$ PBR28 volume of distribution $\left(V_{\mathrm{T}}\right)$ by $+29 \%$ and $+62 \%$ relative to baseline $1 \mathrm{~h}$ and $4 \mathrm{~h}$ after endotoxin injection, respectively. These results demonstrated the time dependence of measurements of endotoxin effects. The peak response occurred 3-5 h post-dose, which informed the design for future human studies. In humans, acute endotoxin administration $(1.0 \mathrm{ng} / \mathrm{kg}$ LPS, i.v.) induced a $30-60 \%$ increase in $\left[{ }^{11} \mathrm{C}\right] \mathrm{PBR} 28 V_{\mathrm{T}}$ in the brain $3 \mathrm{~h}$ after injection [25]. In the rhesus monkeys, a similar dose $\left(1.0 \mathrm{ng} / \mathrm{kg}\right.$ LPS, i.v.) increased $\left[{ }^{11} \mathrm{C}\right]$ PBR2 $8 V_{\mathrm{T}}$ by $+39 \%$ from baseline $2.5 \mathrm{~h}$ post-endotoxin [26].

Altogether, a comparison across different TSPO-PET studies after the LPS challenge highlights an important species difference in the LPS sensitivity. Globally 2.5 to $4 \mathrm{~h}$, a comparable TSPO response ( +40 to $+60 \%$ increase) after LPS challenge could be observed in baboon, rhesus NHP, and human, but the LPS dose administered in baboon was $10^{5}$-fold higher compared to the doses in rhesus or human. Importantly, both the baboon and human studies demonstrated that TSPOPET brain changes after endotoxin challenge were accompanied with changes in subjective sickness behaviour and blood levels of inflammatory cytokines. In the rodent, even higher doses (in the order of $\mathrm{mg} / \mathrm{kg}$ ) are needed to evoke a detectable neuroinflammatory TSPO response (of note, the administration route in rodents is i.p. vs i.v. in NHP and humans). Altogether, this suggests that rhesus monkeys and humans exhibit greater sensitivity to endotoxin compared to rodents and baboons.

The neuroinflammatory response to systemic endotoxin depends on more factors. A study on mice systematically treated with LPS $(0.63 \mathrm{mg} / \mathrm{kg})$ revealed significant age and sex influences, which were reflected by both differential expression of pro-inflammatory factors and an increased ex vivo TSPO ligand uptake, using $\left[{ }^{18} \mathrm{~F}\right] \mathrm{VC} 701$, in aged female mice [27]. Furthermore, the brain regions displayed differential susceptibility to LPS, which is attributable to the number of microglia present and the levels of inflammation-related factors produced by these cells [28]. As such, the systemic endotoxin model can provide valuable new insight on the role of inflammation in the pathogenesis of brain diseases such as stroke, and Parkinson's disease, which will be discussed in the next chapters. LPS-induced systemic inflammation was further used to evaluate the influence on the $\left[{ }^{11} \mathrm{C}\right]-\mathrm{R}-\mathrm{PK} 11195$ TSPO-PET signal in the presence of a pre-existing neuroinflammatory lesion [29]. Here, the authors suggested that the TSPO-PET signal refers to the level of microglial activation rather than the number in activated microglia, an observation that was contradicted by Tournier et al. as discussed below [30]. Finally, Vignal et al. [31] used TSPOPET imaging to evaluate the impact of immune regulating factors on brain $\left[{ }^{18} \mathrm{~F}\right] \mathrm{FEPPA}$ TSPO-PET response. An overview of the studies is presented in Table 2.

Intracerebral administered LPS directly interacts with TLR4 located on astrocytes and microglia, hence locally activating pro-inflammatory microglia and astrocytes. Neurotoxic reactive astrocytes can also be activated indirectly through pro-inflammatory factors expressed by microglia [32]. Even 
Table 2 Overview of TSPO imaging studies in different LPS models

\begin{tabular}{|c|c|c|c|c|c|c|}
\hline PET/SPECT tracer & Rational & LPS model & Species & Imaging time point & $\begin{array}{l}\text { Major outcomes } \\
\text { and additional readouts }\end{array}$ & Ref. \\
\hline$\left[{ }^{18} \mathrm{~F}\right] \mathrm{FEPPA}$ & $\begin{array}{l}\text { Optimization of } \\
\text { radiosynthesis; } \\
\text { impact of astroglial } \\
\text { connexin } 43(\mathrm{Cx} 43) \\
\text { on brain } \\
\text { immunoregulation }\end{array}$ & $\begin{array}{l}\text { Systemic } \\
\text { administration }(5 \\
\mathrm{mg} / \mathrm{kg}, \text { i.p. }) \\
\mathrm{Cx} 43^{\mathrm{fl} / \mathrm{fl}} / \mathrm{hGFAP-Cre} \\
\mathrm{Cx} 43^{\mathrm{fl} / \mathrm{fl}} \text { model }\end{array}$ & $\begin{array}{l}\mathrm{C} 57 \mathrm{Bl} / 6 \mathrm{~J} \\
\text { mice }\end{array}$ & $24 \mathrm{~h}$ post-injection & $\begin{array}{l}\text { - Systemic } \\
\text { inflammation results } \\
\text { in two-fold increase } \\
\text { in TSPO-PET. } \\
\text { - Deletion of astrocyte } \\
\text { Cx43 abolishes the } \\
\text { LPS-induced TSPO } \\
\text { increase }\end{array}$ & $\begin{array}{l}{[45,} \\
31]\end{array}$ \\
\hline$\left[{ }^{11} \mathrm{C}\right]-\mathrm{R}-\mathrm{PK} 11195$ & $\begin{array}{l}\text { Impact of systemic } \\
\text { inflammation on } \\
\text { toxic-induced } \\
\text { neuroinflammation }\end{array}$ & $\begin{array}{l}\text { Systemic } \\
\text { administration (10 } \\
\text { mg/kg, i.p.) after } \\
\text { intracerebral } \\
\text { ethanol-induced } \\
\text { neuroinflammation }\end{array}$ & Rats & 4 days post-injection & $\begin{array}{l}\text { LPS induced higher } \\
\text { TSPO-PET signal. } \\
\text { The number of } \\
\text { activated microglia } \\
\text { in the neurotoxic } \\
\text { lesion is similar in } \\
\text { both conditions. } \\
\text { LPS induced higher } \\
\text { expression of } \\
\text { inflammatory } \\
\text { cytokines }\end{array}$ & [29] \\
\hline$\left[{ }^{18} \mathrm{~F}\right] \mathrm{VC} 701$ & $\begin{array}{l}\text { Evaluation of age and } \\
\text { sex differences }\end{array}$ & $\begin{array}{l}\text { Systemic } \\
\text { administration } \\
(0.63 \mathrm{mg} / \mathrm{kg})\end{array}$ & $\begin{array}{l}\mathrm{C} 57 \mathrm{Bl} / 6 \mathrm{~J} \\
\text { mice }\end{array}$ & $6 \mathrm{~h}$ post-injection & $\begin{array}{l}\text { Pro-inflammatory } \\
\text { response in aged } \\
\text { female is higher } \\
\text { compared to adult } \\
\text { female and aged } \\
\text { male }\end{array}$ & {$[27]$} \\
\hline$\left[{ }^{11} \mathrm{C}\right] \mathrm{PBR} 28$ & $\begin{array}{l}\text { To evaluate the impact } \\
\text { of systemic } \\
\text { inflammation on } \\
\text { TSPO-PET in the } \\
\text { brain; development } \\
\text { of a paradigm to } \\
\text { measure dynamic } \\
\text { microglial changes } \\
\text { in the NHP brain }\end{array}$ & $\begin{array}{l}\text { Systemic } \\
\text { administration: } 0.1 \\
\mathrm{mg} / \mathrm{kg} \text {, i.v., and } 1 \\
\mathrm{ng} / \mathrm{kg} \text {, i.v. }\end{array}$ & $\begin{array}{l}\text { NHP: } \\
\text { baboon } \\
\text { Rhesus } \\
\text { mon- } \\
\text { key }\end{array}$ & $\begin{array}{l}1-5.5 \mathrm{~h} \text { and } \sim 22 \mathrm{~h} \\
\text { post-injection } \\
2.5 \mathrm{~h}, 14 \text { days } \\
\text { post-injection }\end{array}$ & $\begin{array}{l}\text { LPS-induced systemic } \\
\text { inflammation } \\
\text { produces a } \\
\text { detectable } \\
\text { TSPO-PET signal in } \\
\text { the brain mediated } \\
\text { by inflammatory } \\
\text { cytokines. } \\
\text { The } \\
\text { colony-stimulating } \\
\text { factor } 1 \text { receptor } \\
\text { kinase inhibitor } \\
\text { depletes brain } \\
\text { microglia and } \\
\text { induces a significant } \\
\text { decrease in the } \\
\text { TSPO-PET signal, } \\
\text { which recovers after } \\
12 \text { days }\end{array}$ & $\begin{array}{l}{[26,} \\
24]\end{array}$ \\
\hline$\left[{ }^{11} \mathrm{C}\right] \mathrm{PBR} 28$ & $\begin{array}{l}\text { To evaluate the impact } \\
\text { of systemic } \\
\text { inflammation on } \\
\text { TSPO-PET in the } \\
\text { brain }\end{array}$ & $\begin{array}{l}\text { Systemic } \\
\text { administration (1 } \\
\text { ng/kg, i.v.) }\end{array}$ & Human & $3 \mathrm{~h}$ & $\begin{array}{l}\text { First in a human } \\
\text { demonstration that a } \\
\text { systemic LPS } \\
\text { challenge induces } \\
\text { microglial activation } \\
\text { in the brain }\end{array}$ & $\begin{array}{l}{[25,} \\
46]\end{array}$ \\
\hline$\left[{ }^{11} \mathrm{C}\right]-\mathrm{R}-\mathrm{PK} 11195$ & $\begin{array}{l}\text { Model of maternal } \\
\text { infection as a risk } \\
\text { factor for } \\
\text { periventricular } \\
\text { leukomalacia and } \\
\text { cerebral palsy }(\mathrm{CP}) \\
\text { in neonates }\end{array}$ & $\begin{array}{l}\text { Intra-uterine exposure } \\
\text { in pregnant rabbits } \\
(20 \mu \mathrm{g} / \mathrm{kg})\end{array}$ & Rabbit & 1-7 days post-injection & $\begin{array}{l}\text { Increased TSPO-PET } \\
\text { in the brain and } \\
\text { increased } \\
\text { inflammatory } \\
\text { markers are detected } \\
\text { up to } 2 \text { weeks after } \\
\text { birth }\end{array}$ & [47] \\
\hline$\left[{ }^{18} \mathrm{~F}\right] \mathrm{DPA}-713$ & $\begin{array}{l}\text { To evaluate if } \\
\text { TSPO-TEP reveals } \\
\text { specifically the pro- } \\
\text { or }\end{array}$ & $\begin{array}{l}\text { Cultured rodent } \\
\text { astrocytes, } \\
\text { microglia and } \\
\text { macrophages }\end{array}$ & Mice & & $\begin{array}{l}\text { TSPO expression } \\
\text { corresponds to a } \\
\text { pro-inflammatory } \\
\text { phenotype }\end{array}$ & {$[33]$} \\
\hline
\end{tabular}


Table 2 (continued)

\begin{tabular}{|c|c|c|c|c|c|c|}
\hline PET/SPECT tracer & Rational & LPS model & Species & Imaging time point & $\begin{array}{l}\text { Major outcomes } \\
\text { and additional readouts }\end{array}$ & Ref. \\
\hline & $\begin{array}{l}\text { anti-inflammatory } \\
\text { phenotype }\end{array}$ & $\begin{array}{l}\text { stimulated with } \\
\text { TNF, LPS and } \\
\text { IL-4; mice injected } \\
\text { with AdTNF or } \\
\text { IL-4 }\end{array}$ & & & & \\
\hline$\left[{ }^{123} \mathrm{I}\right] \mathrm{CLINDE}$ & $\begin{array}{l}\text { Determine the cell } \\
\text { population in which } \\
\text { TSPO is altered } \\
\text { using } \\
\text { fluorescence-- } \\
\text { activated cell sorting } \\
\text { on } \\
\text { radioligand-treated } \\
\text { tissue }\end{array}$ & $\begin{array}{l}\text { Intracerebral } \\
\quad \text { (hippocampus) (10 } \\
\mu \mathrm{g})\end{array}$ & Rat & 3 days post-injection & $\begin{array}{l}\text { LPS induces a } \\
\text { microglial } \\
\text { expansion and an } \\
\text { increase in } \\
\text { microglial TSPO } \\
\text { binding }\end{array}$ & {$[30]$} \\
\hline $\begin{array}{l}{\left[{ }^{11} \mathrm{C}\right]-\mathrm{R}-\mathrm{PK} 11195,} \\
{\left[{ }^{11} \mathrm{C}\right] \mathrm{DAA} 1106,} \\
{\left[{ }^{11} \mathrm{C}\right] \mathrm{PBR} 28,} \\
{\left[{ }^{18} \mathrm{~F}\right] \mathrm{DPA}-714,} \\
{\left[{ }^{18} \mathrm{~F}\right] \mathrm{GE}-180,} \\
{\left[{ }^{18} \mathrm{~F}\right] \text { fluoromethyl-PB- }} \\
\text { R2 } \\
{ }_{48-51,34,52]}\end{array}$ & $\begin{array}{l}\text { Validation and } \\
\text { comparison of } \\
\text { TSPO-PET ligands; } \\
\text { validation of } \\
\text { pharmacokinetic } \\
\text { quantification } \\
\text { models }\end{array}$ & $\begin{array}{l}\text { Intracerebral } \\
\quad(\text { striatum })(1 \mu \mathrm{g}, 10 \\
\quad \mu \mathrm{g}, 50 \mu \mathrm{g})\end{array}$ & Rat & $\begin{array}{l}\text { 3-4 days } \\
\text { post-injection/- } \\
\text { longitudinal after } \\
\text { injection }\end{array}$ & $\begin{array}{l}\text { 2nd generation TSPO } \\
\text { ligands reveal a } \\
\text { higher uptake } \\
\text { compared to that of } \\
{\left[{ }^{11} \mathrm{C}\right]-\mathrm{R}-\mathrm{PK} 11195 .} \\
\text { IHC characterization } \\
\text { of the LPS model }\end{array}$ & $\begin{array}{l}{[40,35,} \\
\quad 38, \\
44, \\
39\end{array}$ \\
\hline$\left[{ }^{18} \mathrm{~F}\right] \mathrm{CB} 251$ & $\begin{array}{l}\text { Comparison and } \\
\text { validation of a new } \\
\text { 3rd generation } \\
\text { TSPO ligand; } \\
\text { characterization and } \\
\text { identification of } \\
\text { immune cells } \\
\text { contributing to } \\
\text { LPS-induced } \\
\text { neuroinflammation }\end{array}$ & $\begin{array}{l}\text { Intracerebral } \\
\quad(\text { striatum })(5 \mu \mathrm{g} / 2 \\
\mu \mathrm{l})\end{array}$ & Mice & 4 days post-injection & $\begin{array}{l}{\left[{ }^{18} \mathrm{~F}\right] \mathrm{CB} 251 \text { does not }} \\
\text { show a differential } \\
\text { affinity for the } \\
\text { TSPO } \\
\text { polymorphism; } \\
\text { following } \\
\text { LPS-induced } \\
\text { neuroinflammation, } \\
\text { peripheral immune } \\
\text { cells cross the BBB } \\
\text { and actively } \\
\text { contribute to the } \\
\text { TSPO-PET signal. } \\
\text { Bioluminescence } \\
\text { studies to identify } \\
\text { the contribution of } \\
\text { peripheral immune } \\
\text { cells to the brain } \\
\text { immune response }\end{array}$ & {$[37]$} \\
\hline
\end{tabular}

though both pro-inflammatory microglia and astrocytes contribute to the LPS-induced TSPO-PET signal [33-35, 30], microglia are abundantly present over astrocytes, suggesting that the TSPO-PET signal in the intracerebral induced LPS model is mainly due to an increase in microglial density. In vitro studies demonstrated that LPS slightly decreased TSPO gene expression in human microglia and $\left[{ }^{3} \mathrm{H}\right] \mathrm{PBR} 28$ binding sites in human macrophages [36]. Building on these findings, an innovative ex vivo technique using fluorescenceactivated cell sorting of radioligand-treated tissue reported that while LPS did not change radioactivity per cell in microglia, LPS dramatically increased the number of microglia per gram of tissue [30]. Despite possible LPS binding to endothelial cells [17], there is no evidence for changes in TSPO levels in endothelial cells following LPS stimulation [33]. Based on the robust imaging [25] and immunohistochemistry [34] literature reporting LPS-induced increases in TSPO signal, findings point to LPS increasing the number of TSPO-expressing microglia and not the number of TSPO per microglia. TSPO imaging of acute LPS effects should be more accurately characterized as capturing "microglial proliferation", rather than assessing "microglial activation". A recent multimodal imaging study combining TSPO-PET and bioluminescence imaging demonstrated that peripheral immune cells cross the blood-brain barrier, exacerbate the LPS-induced neuroinflammation to produce higher levels of neurotoxicity and actively 
contribute to the TSPO-PET signal. For this study, the authors used a new TSPO ligand, $\left[{ }^{18} \mathrm{~F}\right] \mathrm{CB} 251$, which has a higher affinity for TSPO compared to ligands such as PK11195, PBR28 and GE-180 [37]. In general, intracerebral induced neuroinflammation by LPS is an attractive experimental model to confirm or compare the sensitivity of new TSPO radioligands in a situation of acute immune activation in rodents [34, 38-40]. Additionally, this model is also used to evaluate new PET ligands specific for other proinflammatory microglial-specific targets, such as $\mathrm{CB} 2$ and $\mathrm{P} 2 \mathrm{X} 7$, in comparison to validated TSPO ligands [35, 41]. A review of the literature highlights the important differences between experimental protocols in terms of injected dose, site of injection and the time point of imaging (Table 2). Intracerebral LPS doses vary from $1[35,40]$ to $5-10 \mu \mathrm{g}$ $[42,43]$ and even up to $50 \mu \mathrm{g}[34,44]$; injection is generally performed in the striatum but also in the hippocampus and substantia nigra; finally, imaging time points vary from hours to days or even weeks post-injection $[42,43]$. These experimental differences undoubtedly affect the neuroinflammatory response and its imaging readout, rendering the comparison between studies almost impossible.

\section{Stroke}

Neuroinflammation was truly identified as an essential component of the pathophysiology of stroke in the mid- to late 1990s [53-55], although the identification of TSPO glial expression was originally described after cerebral ischaemia, when TSPO was still referred to as the peripheral benzodiazepine receptor [56, 7]. Only about $10-15$ years later, those ex vivo observations in animal models were confirmed by in vivo PET imaging in clinical settings [57-59]. In 2015, Boutin and Pinborg published a review on the literature of TSPO-PET imaging in stroke covering brain ischaemia models and clinical studies [60]. Overall, that review [60] covered clinical studies investigating (i) TSPO after stroke using $\left[{ }^{11} \mathrm{C}\right]-\mathrm{R}-\mathrm{PK} 11195$ [58], (ii) preclinical studies in primates $[61,62]$ using a clinical scanner and $\left[{ }^{11} \mathrm{C}\right]-\mathrm{R}$ PK11195 as well as (iii) the first preclinical studies using small animal dedicated scanners. These studies aimed to evaluate - at the time - new tracers such as $\left[{ }^{11} \mathrm{C}\right]$ PBR28 [63] or $\left[{ }^{18} \mathrm{~F}\right] \mathrm{DPA}-714[64]$ or better determine the time course of TSPO expression following focal ischemia [65]. Altogether, these first studies were extremely helpful to demonstrate the importance of neuroinflammation after stroke and the value of TSPO-PET imaging to quantify it, and they provided invaluable information in terms of the study design to future preclinical and clinical studies. Therefore, in the following paragraphs, we will only review the literature on TSPO imaging in stroke models that has been published since the most recent paper included in that review at the time of publication, which was Tiwari et al. [66]. For this section, we used the following search in PubMed, "(omega* OR TSPO OR PBR OR PK11195) AND (PET OR positron) AND (brain OR cereb*) AND (stroke OR ischem* OR ischaem*) AND (rat OR mouse OR mice OR animal* OR experimental OR pig OR gerbil OR rabbit OR guinea OR primate OR dog OR cat) AND (English[ lang])", limiting the search to 2015-2021. This returned initially 52 records, excluding those not using stroke models, reviews and clinical research papers, and 26 references were finally kept for this section. The results of all these studies have been summarized in Table 3; most of them did confirm their in vivo PET results using immunohistochemistry and/or autoradiography, but these results will not be discussed in full details here; instead, a short summary of those ex vivo/in vitro results can be found in Table 3 .

To test new TSPO tracers, stroke models present the advantages of being clinically relevant and to induce a strong $\mathrm{TSPO}^{+}$microglial activation that has been demonstrated both preclinically $[8,11]$ and clinically $[57,58,60]$. In this context, Boutin et al. used a transient model of middle cerebral artery occlusion (MCAO) in rats to evaluate the then-new TSPO tracer $\left[{ }^{18} \mathrm{~F}\right] \mathrm{GE}-180$ [67] and demonstrated a superior uptake, ipsi-/contralateral ratio and $\mathrm{BP}_{\mathrm{ND}}$ for $\left[{ }^{18} \mathrm{~F}\right] \mathrm{GE}-180$ when compared to $\left[{ }^{11} \mathrm{C}\right]-\mathrm{R}-\mathrm{PK} 11195$. This preclinical study and another using LPS-induced milder neuroinflammation [40] positively demonstrated the benefit in terms of the signal-to-noise ratio of $\left[{ }^{18} \mathrm{~F}\right] \mathrm{GE}-180$ vs $\left[{ }^{11} \mathrm{C}\right]-\mathrm{R}-\mathrm{PK} 11195$. However, clinical studies demonstrated that, for reasons that remain unclear, the brain pharmacokinetics of $\left[{ }^{18} \mathrm{~F}\right] \mathrm{GE}-180$ were slower - i.e. more than one could anticipate - and less favourable in man as those observed in rat. Despite this observation, several studies have recently shown the value of this tracer to measure neuroinflammation in vivo [68-73]. In the same line, Fujinaga et al. used a stroke model in rats to test and select new TSPO tracer candidates and identified that amongst those 2-(5-(6-[ ${ }^{18}$ F]fluoropyridin-3-yl)-2-oxobenzo[d]oxazol-3(2H)yl)-N-methyl-N-phenylacetamide (compound $d$ in [74]) and $\left[{ }^{18} \mathrm{~F}\right] 5$ (N-(4-[18F]fluorobenzyl)-N-methyl-2-(7-methyl-8oxo-2-phenyl-7,8-dihydro-9H-purin-9-yl)acetamide) [75] were the best candidates with better signal-to-noise ratio than $\left[{ }^{11} \mathrm{C}\right]-\mathrm{R}-\mathrm{PK} 11195$. Other TSPO tracers have been evaluated using stroke models, such as $\left[{ }^{18} \mathrm{~F}\right]$ VUIIS 1008 [76], $\left[{ }^{18} \mathrm{~F}\right]$ VUIIS1008A [77] and $\left[{ }^{18} \mathrm{~F}\right] \mathrm{F}-\mathrm{DPA}[78]$. Generally, those new tracers showed potential with a better signal-tonoise ratio than that of $\left[{ }^{11} \mathrm{C}\right]-\mathrm{R}-\mathrm{PK} 11195$ that they aim to replace. However, the direct comparison of $\left[{ }^{18} \mathrm{~F}\right]$ VUIIS 1008 with $\left[{ }^{18} \mathrm{~F}\right] \mathrm{DPA}-714$ revealed that $\left[{ }^{18} \mathrm{~F}\right]$ VUIIS1008 yielded no gain in term of signal-to-noise ratio when compared to $\left[{ }^{18} \mathrm{~F}\right]$ DPA-714, with similar ipsi- to contralateral ratio and $\mathrm{BP}_{\mathrm{ND}}$ values. When comparing, a posteriori, data reported for $\left[{ }^{18} \mathrm{~F}\right]$ VUIIS1008A, $\left[{ }^{18} \mathrm{~F}\right]$ VUIIS1008 and $\left[{ }^{18} \mathrm{~F}\right] \mathrm{DPA}-714$, the same group seemed to indicate that it was also the case for $\left[{ }^{18} \mathrm{~F}\right]$ VUIIS1008A [77]. However, in a more recent study using $\left[{ }^{18} \mathrm{~F}\right]$ VUIIS 1008 and $\left[{ }^{18} \mathrm{~F}\right] \mathrm{DPA}-714$, a significant 


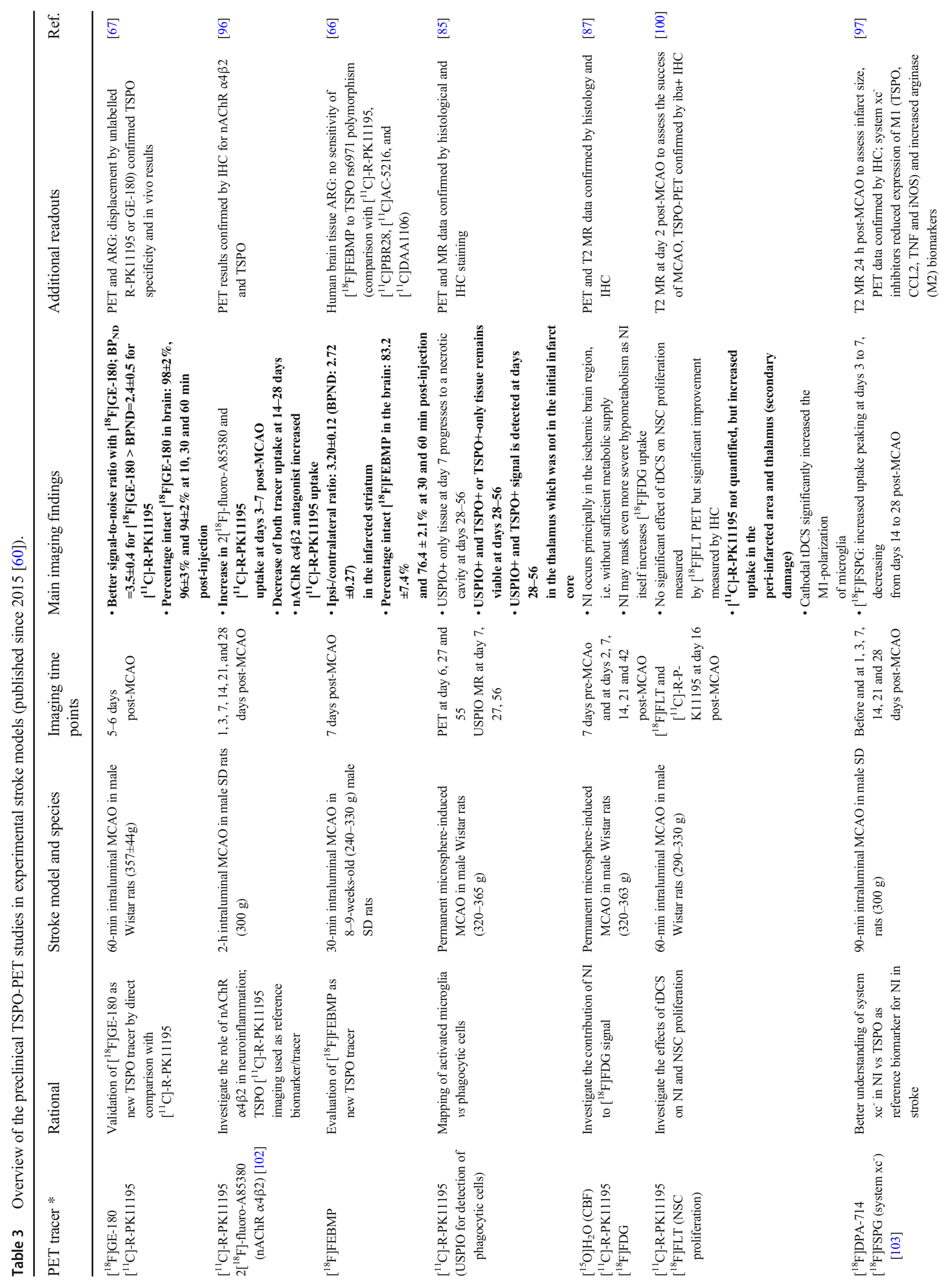




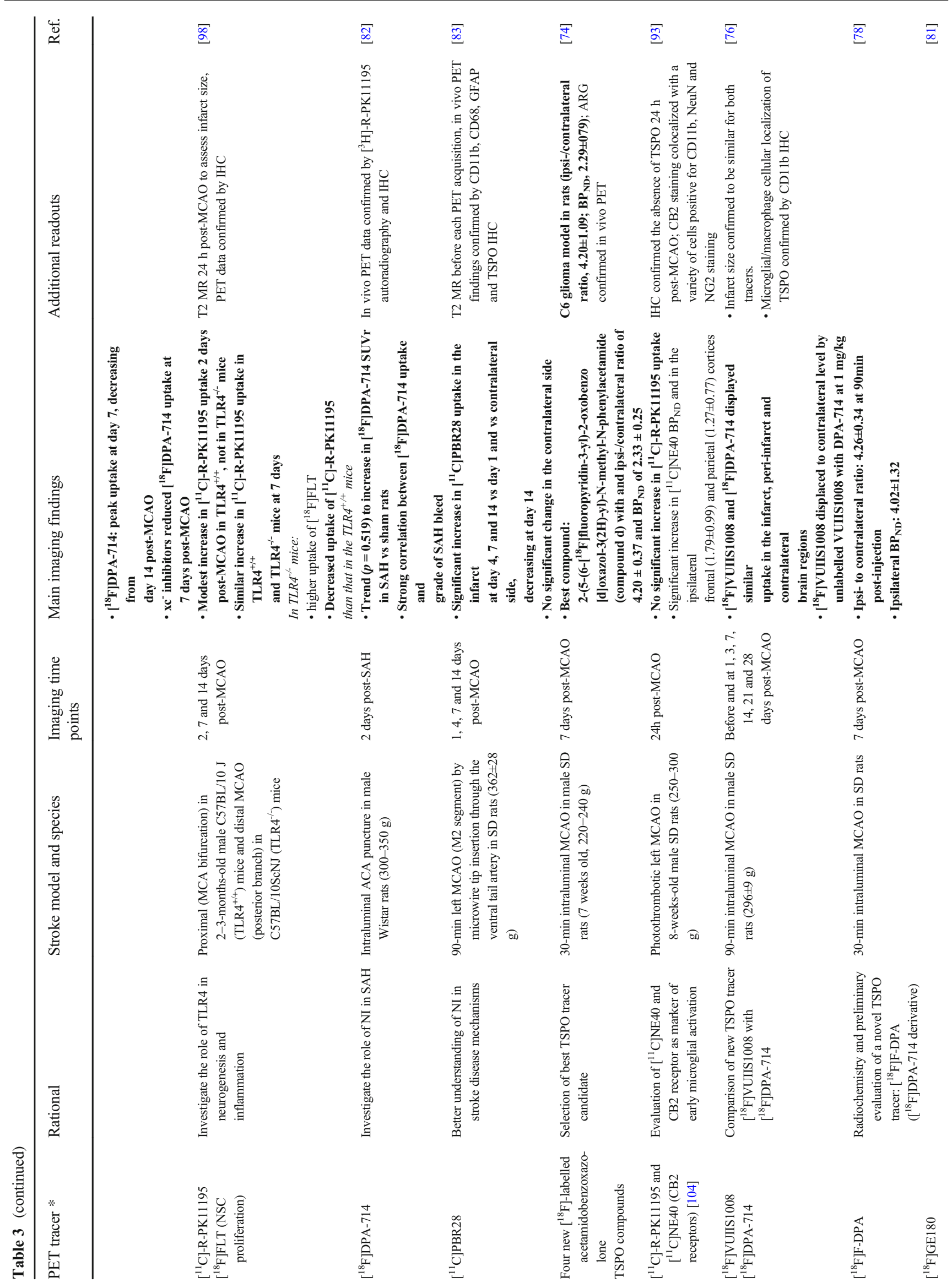




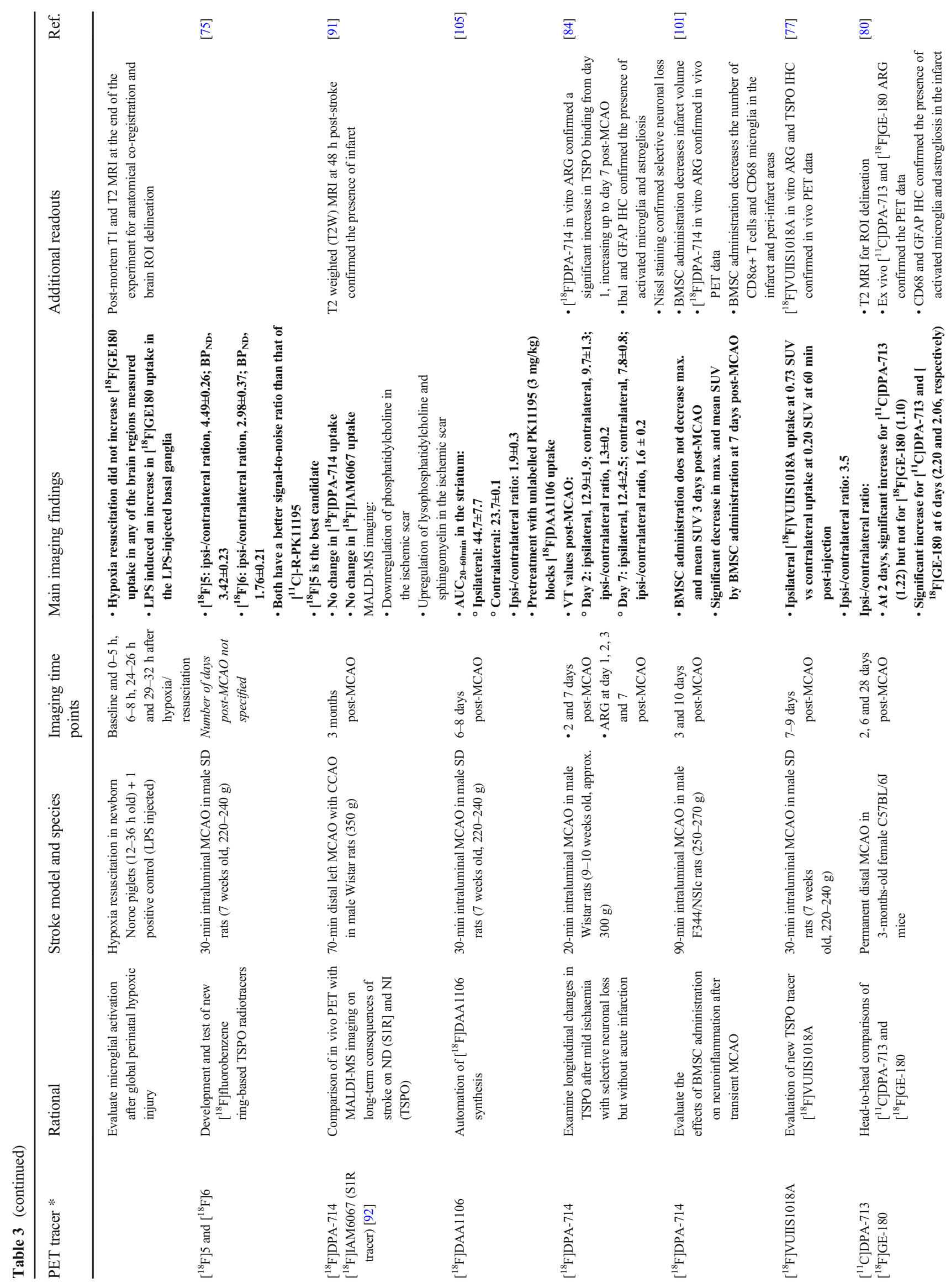




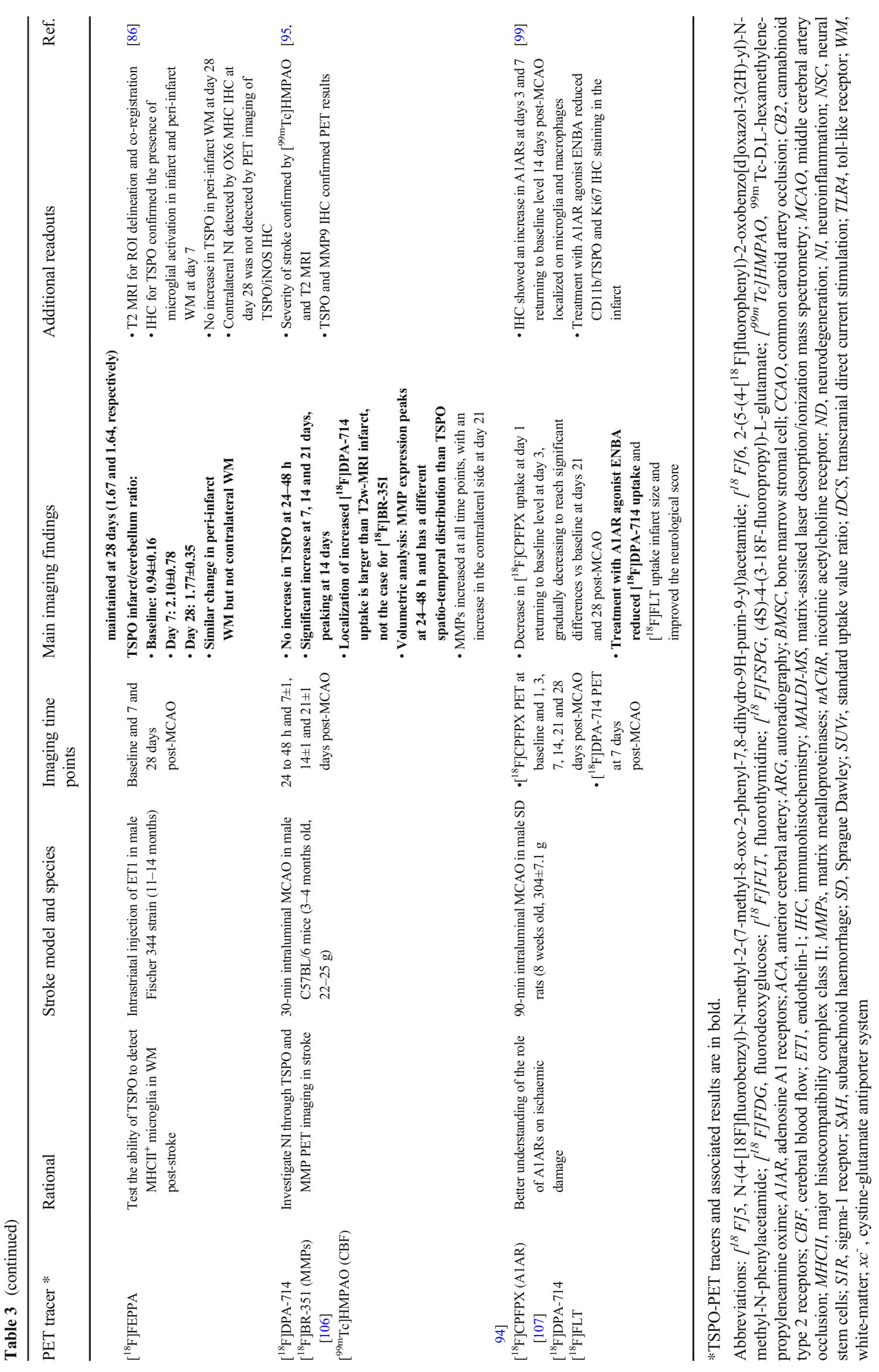


increase in uptake from day 3 post-MCAO was reported, peaking at day 7 and remaining elevated up to day 14 when compared to baseline [76], in line with previous reports [65]. The same observation can be made for $\left[{ }^{18} \mathrm{~F}\right] \mathrm{F}$-DPA in terms of binding characteristics and uptake levels. However, its lower metabolism rate when compared to $\left[{ }^{18} \mathrm{~F}\right] \mathrm{DPA}-714$ is an interesting feature of this new tracer [79]. Also performing a direct comparison between 2nd generation TSPO tracers, Chaney et al. [80] compared $\left[{ }^{11} \mathrm{C}\right] \mathrm{DPA}-713$ and $\left[{ }^{18} \mathrm{~F}\right] \mathrm{GE}-180$ in a model of permanent MCAO in mice. In this study, they showed that, 1 day post-MCAO, $\left[{ }^{11} \mathrm{C}\right] \mathrm{DPA}-713$ uptake was significantly increased $(+22 \%)$ whereas $\left[{ }^{18} \mathrm{~F}\right] \mathrm{GE}-180$ uptake was not $(+10 \%)$; 6 days post-MCAO, both tracers exhibited similar uptake increases $(+120 \%$ and $+106 \%$, respectively) which remained elevated up to 28 days post-MCAO $(+67 \%$ and $+64 \%$, respectively) [80].

The other major use of TSPO imaging in stroke models is to better understand the role of various neuroinflammation processes following experimental stroke. In that perspective, some studies used TSPO-PET imaging to better characterize the temporal and anatomical evolution of neuroinflammation in various models of experimental stroke, some of them new. De Lange et al. [81] used $\left[{ }^{18} \mathrm{~F}\right] \mathrm{GE}-180$ to evaluate acute neuroinflammation in a model of hypoxia resuscitation in newborn piglets. Considering the numerous reports showing that it takes approximately 3 days for microglia to proliferate and TSPO expression to increase in stroke and LPS model of neuroinflammation, unsurprisingly this study did not detect any significant change in $\left[{ }^{18} \mathrm{~F}\right] \mathrm{GE}-180$ between 5 and $32 \mathrm{~h}$ post-hypoxia. Similarly, in a model of subarachnoid haemorrhage (SAH) in rats, Thomas et al. [82] showed only a trend ( $p$ $=0.0519)$ in an increase in $\left[{ }^{18} \mathrm{~F}\right] \mathrm{DPA}-714$ uptake 2 days post$\mathrm{SAH}$. In a very clinically relevant model of focal temporary MCAO using a minimally invasive technique through the insertion of a microwire tip via the ventral tail artery, Toth et al. [83] demonstrated significant increases in $\left[{ }^{11} \mathrm{C}\right]$ PBR2 8 uptake in the infarct at day 4,7 and 14 post-MCAO, although $\left[{ }^{11} \mathrm{C}\right]$ PBR2 8 uptake started to decrease at day 14 . Their results are in line with other studies using more conventional models of stroke in rats $[76,65]$ such as those developed by Miyajima et al. [84] described a significant increase in $\left[{ }^{18} \mathrm{~F}\right] \mathrm{DPA}-714$ uptake in the infarct from day 2 maintained up to day 7 postMCAO (20-min intraluminal MCAO). Taken altogether, these results confirmed that in these models of acute brain injury (permanent or temporary MCAO, SAH or hypoxia), the microglial/macrophage infiltration responsible for the TSPO increase takes approximately 3 days to become detectable, peaks about 1 week after injury and then slowly decreases in intensity afterwards.

On top of characterizing the temporal evolution of TSPO expression after stroke, some studies used TSPO-PET tracers combined with other PET tracers or other imaging methods to investigate further processes in stroke. Walter et al. combined $\left[{ }^{11} \mathrm{C}\right]-\mathrm{R}-\mathrm{PK} 11195$ PET with USPIO MR imaging to differentiate nonphagocytic $\left(\mathrm{TSPO}^{+}\right.$only) vs phagocytic $\left(\mathrm{TSPO}^{+} \&\right.$ $\mathrm{USPIO}^{+}$) neuroinflammatory cells in a permanent microsphere-induced model of MCAO in rats 6-7, 26-27 and 55-56 days post-stroke [85]. Such combination of techniques allowed the authors to determine that brain regions with early phagocytic signal $\left(\mathrm{USPIO}^{+}\right)$at day 7 will irremediably evolve into necrotic tissue, whereas tissue exclusively positive for TSPO will remodel but remains viable thereafter (days 27 and 55 post-stroke). Looking at white matter damage after stroke, Al-Khishman et al. used $\left[{ }^{18}\right.$ F]FEPPA TSPO-PET imaging and reported a significant increase at 7 and 28 days in the striatal infarct and peri-infarct white matter (WM) [86]. In the contralateral WM, they were able to detect $\mathrm{MHCII}^{+}$cells by either $\left[{ }^{18} \mathrm{~F}\right]$ FEPPA TSPO-PET or TSPO IHC. In a way, this highlights the fact that TSPO is an imperfect surrogate marker of activated microglia and may be unable to detect certain phenotype of microglia.

Combining $\left[{ }^{11} \mathrm{C}\right]$-R-PK11195 and $\left[{ }^{18} \mathrm{~F}\right] \mathrm{FDG}$, Backes et al. [87] performed a study investigating the potential contribution of neuroinflammation to $\left[{ }^{18} \mathrm{~F}\right] \mathrm{FDG}$ signal in the same model as Walter et al. [85]. Not unexpectedly, they found that microglial activation and macrophage infiltration could indeed be the source of a significant $\left[{ }^{18} \mathrm{~F}\right]$ FDG uptake at day 7 post-stroke in the peri-infarct region where $\left[{ }^{18} \mathrm{~F}\right] \mathrm{FDG}$ uptake was initially significantly decreased at day 1 . These observations are in line with previous use of $\left[{ }^{18} \mathrm{~F}\right] \mathrm{FDG}$ to image inflammation [88-90], although very unspecifically especially in the brain where the basal $\left[{ }^{18} \mathrm{~F}\right] \mathrm{FDG}$ uptake is very high mostly due to neuronal activity. They concluded that in such brain regions, where metabolic supply was already decreased and likely insufficient, the contribution of neuroinflammation to the $\left[{ }^{18} \mathrm{~F}\right] \mathrm{FDG}$ signal might actually mask even more severe hypometabolism. Also looking at complementing PET imaging with another tracer and method, Henderson et al. [91] combined PET imaging with $\left[{ }^{18} \mathrm{~F}\right] \mathrm{DPA}-714$ and the newly developed sigma-1 receptor (tracer $\left[{ }^{18}\right.$ F]IAM6067 [92] and post-mortem mass spectrometry imaging (MALDI-TOF) to look at the long-term consequences of distal MCAO. These authors did not find any changes in $\left[{ }^{18} \mathrm{~F}\right] \mathrm{DPA}-714$ and $\left[{ }^{18} \mathrm{~F}\right] \mathrm{IAM} 6067$, suggesting that 3 months post-MCAO, neuroinflammation had resolved and that neuronal loss directly in or at a distance of the infarct was undetectable using S1R PET imaging. MALDI-TOF MS however revealed distinctive changes in the peri-infarct scar with a decrease in phosphatidylcholines, which are otherwise found in the healthy tissue, whereas sphingomyelin and lysophosphatidylcholine were significantly decreased in the same region. The MALDITOF MS combined with the TSPO-PET data suggest that neuroinflammation had fully recessed in the peri-infarct region 3 months after MCAO where scarification and repair were taking place. Using $\left[{ }^{11} \mathrm{C}\right]-\mathrm{R}-\mathrm{PK} 11195$ PET imaging as a reference for neuroinflammation imaging, Hosoya [93] 
tested the potential of the cannabinoid type 2 receptor (CB2) as an early marker for neuroinflammation $24 \mathrm{~h}$ post-MCAO. They reported a significant increase in $\left[{ }^{11} \mathrm{C}\right] \mathrm{NE}-40$ uptake but no change in $\left[{ }^{11} \mathrm{C}\right]-\mathrm{R}-\mathrm{PK} 11195$ uptake. Further immunohistochemistry experiments revealed that most of the $\mathrm{CB} 2^{+}$cells were microglia $\left(\mathrm{CD} 11 \mathrm{~B}^{+}\right)$together with some neuron-glial antigen 2-positive $\left(\mathrm{NG}^{+}\right)$cells putatively identified as monocytes, supporting $\mathrm{CB} 2$ and $\left[{ }^{11} \mathrm{C}\right] \mathrm{NE}-40$ as a potential candidate of early microglial activation, although in that case, the exact phenotype of the microglia remains to be established. Finally, investigating the relationship between microglial activation and metalloproteases (MMP), Zinnhardt et al. [94] and Barca et al. [95] investigated TSPO expression with $\left[{ }^{18} \mathrm{~F}\right] \mathrm{DPA}-714$ and MMP levels with $\left[{ }^{18} \mathrm{~F}\right] \mathrm{BR}-351$. These studies showed a differential temporal expression between TSPO and MMP; MMP levels increased early (days 1-7 post-MCAO) and remained elevated while TSPO levels increased later (days 7-21 post-MCAO) in the infarct. Interestingly, MMP were also significantly increased in the contralateral side at 21 days, where no change in TSPO could be detected. By refining the differential analysis of the two tracers and comparing it with the $\mathrm{T}_{2}{ }^{-}$weighted MR map of the infarct, Barca et al. [95] concluded that this differential pattern likely represented a different phase of acute inflammation in the infarct followed by remodelling in the peri-infarct and contralateral side.

Focusing more on therapeutic approaches in relation with neuroinflammation, Martin et al. published various papers using TSPO as reference for neuroinflammation imaging in which they examine the involvement of $\alpha 4 \beta 2$ nicotinic acetylcholine receptor (nAChR) [96], the cystine-glutamate antiporter system $\mathrm{xc}^{-}$[97], toll-like receptor 4 (TLR4) [98] and the adenosine A1 receptors (A1AR) [99] in the regulation of neuroinflammation after stroke. Overall, they described a very consistent time course of TSPO expression across studies and models. They also demonstrated that $2\left[{ }^{18} \mathrm{~F}\right]$-fluoroA85380 ( $\alpha 4 \beta 2 \mathrm{nAChR}$ ) and $\left[{ }^{18} \mathrm{~F}\right] \mathrm{FSPG}$ (system xc') uptakes were maximum at 7 and 3-7 days post-stroke, respectively, and decreased thereafter, paralleling TSPO levels. Conversely, $\left[{ }^{18} \mathrm{~F}\right] \mathrm{CPFPX}$ (A1 adenosine receptor, A1AR) followed an inverse pattern to TSPO levels along time with an early decrease $24 \mathrm{~h}$ post-stroke returning to baseline at day 3 followed by a subsequent progressive decrease reaching significance vs baseline at days $21-28$ post-MCAO. It must be noted that there was a slight discrepancy between the temporal expression of the A1AR measured by PET and immunohistochemistry as for the latter, there was no decrease observed at day 1 and no significant decrease at days $21-28$ vs baseline. Altogether, these studies demonstrated that these systems are altered following stroke. More importantly, these studies also demonstrated that modulation of the $\alpha 4 \beta 2$ $\mathrm{nAChR}$ by the selective antagonist $\mathrm{Dh} \beta \mathrm{E}$ increased $\left[{ }^{11} \mathrm{C}\right]-\mathrm{R}$ PK11195 uptake [96], whereas treatment with inhibitors of the system $\mathrm{xc}^{-}$[97] or the A1AR agonist ENBA [99] significantly decreased neuroinflammation as measured by $\left[{ }^{18} \mathrm{~F}\right] \mathrm{DPA}-714$ uptake and immunohistochemistry. In the same line, $\left[{ }^{11} \mathrm{C}\right]-\mathrm{R}$ PK11195 PET imaging showed that neuroinflammation was reduced in TLR $4^{-/-}$mice 2 days but not 7 days post-MCAO [98]. Similarly, Braun et al. [100] investigated the effect of transcranial direct current stimulation (tDCS) on neuroinflammation and neural stem cell (NSC) proliferation 16 days postMCAO and showed no effect of tDCS on NSC proliferation as measured by $\left[{ }^{18} \mathrm{~F}\right] \mathrm{FLT}$ PET but did observe an effect when measured by immunohistochemistry; $\left[{ }^{11} \mathrm{C}\right]-\mathrm{R}-\mathrm{PK} 11195$ was unfortunately not quantified, and only a noticeable uptake in the peri-infarct and thalamus was reported. Finally, Tan et al. [101] evaluated the therapeutic effect of intravenous administration of bone marrow stromal cell (BMSC) to modulate the inflammatory response to stroke. They showed that $\left[{ }^{18} \mathrm{~F}\right] \mathrm{DPA}-714$ uptake increased 3 days post-MCAO similarly in vehicle and BMSC-treated rats, but 7 days post-MCAO, $\left[{ }^{18} \mathrm{~F}\right] \mathrm{DPA}-714$ uptake was significantly reduced in BMSCtreated animals compared to vehicle animals. The in vivo PET results and therapeutic effect of the BMSC treatment were confirmed by autoradiography and were correlated with a decrease in infarct volume as well as a decrease in the number of CD8 $\alpha+\mathrm{T}$ cells and CD68 microglia in the infarct and peri-infarct areas.

\section{Neuroinflammation in models of chronic neurodegenerative diseases}

\section{Alzheimer's disease (AD)}

Similarly to stroke and other neurodegenerative diseases, neuroinflammation emerged as a potential essential player in the pathophysiology of AD in the 1990s [108, 109], although its presence was already acknowledged by Alois Alzheimer himself when he first described the neuropathological features of $\mathrm{AD}$ [110-112].

In 2019, Chaney et al. published a review of neuroinflammation imaging in Alzheimer diseases [113] that included preclinical references up to the work of Lopez-Picon et al. [114]. For this paragraph, we used the following PubMed search, "(omega* OR TSPO OR PBR OR PK11195) AND (PET OR positron) AND (brain OR cereb*) AND (Alzheimer) AND (rat OR mouse OR mice OR animal* OR experimental OR pig OR gerbil OR rabbit OR guinea OR model OR dog OR cat) AND (English[ lang])", including all references since 2018; this search returned 37 records including 6 reviews. After exclusion of the reviews, clinical papers and non-PET imaging manuscripts returned by this search, 8 original research papers that included in vivo TSPO imaging were kept in this review and are summarized in Table 4. 
Table 4 Overview of the preclinical TSPO-PET/SPECT imaging studies in Alzheimer's disease models (published since 2019 [113])

\begin{tabular}{|c|c|c|c|c|c|c|}
\hline PET tracer $*$ & Rational & AD model & $\begin{array}{l}\text { Imaging time } \\
\text { points }\end{array}$ & Main imaging findings & Additional readouts & Ref. \\
\hline $\begin{array}{l}{\left[{ }^{18} \mathrm{~F}\right] \mathrm{GE} 180} \\
{\left[{ }^{15} \mathrm{O}\right] \mathrm{H}_{2} \mathrm{O}(\mathrm{CBF})}\end{array}$ & $\begin{array}{l}\text { Investigate the } \\
\text { short-term effects } \\
\text { of space } \\
\text { radiation (model by } \\
{ }^{56} \mathrm{Fe} \text { irradiation at } \\
4 \text { months of age) } \\
\text { on brain ageing } \\
\text { and AD }\end{array}$ & $\begin{array}{l}\text { 3.5-months-old } \\
\text { male and female } \\
\text { APPswe/PS1d- } \\
\text { E9 Tg mice }\end{array}$ & $\begin{array}{l}\text { At baseline } \\
(3.5 \text { month } \\
\text { old) and } \\
1.5-2 \text { month } \\
\text { post-- } \\
\text { irradiation }\end{array}$ & $\begin{array}{l}\text { - Irradiation induced a small } \\
\text { decrease in the initial } \\
(0-20 \text { min post-inj.) and } \\
\text { late }\left[{ }^{18} \mathrm{~F}\right] \mathrm{GE} 180 \text { uptake } \\
(20-60 \text { min post-inj.) in } \mathrm{Tg} \\
\text { female mice only } \\
\text { - No changes in any of the } \\
\text { other groups } \\
\text { - No change in CBF }\end{array}$ & $\begin{array}{l}\text { - Irradiation induces a } \\
\text { reduction in } \mathrm{A} \beta \text { and } \\
\text { CD68 IHC staining in Tg } \\
\text { female only } \\
\text { - No effect on TSPO, Iba-1 } \\
\text { or GFAP staining in any } \\
\text { of the group }\end{array}$ & [125] \\
\hline $\begin{array}{l}{\left[{ }^{18} \mathrm{~F}\right] \mathrm{GE}-180} \\
{\left[{ }^{18} \mathrm{~F}\right] \text { florbetaben }} \\
\quad(\mathrm{A} \beta)[126 \\
127]\end{array}$ & $\begin{array}{l}\text { Establish serial } \\
\text { small-animal } \\
\text { PET as a tool for } \\
\text { therapy } \\
\text { monitoring of the } \\
\text { new model of AD } \\
\text { App }^{\text {NL-G-F }} \text { mice }\end{array}$ & $\begin{array}{l}\text { Males and females } \\
\text { App }^{\text {NL-G-F }} \\
\text { knock-in [128] } \\
\text { and WT mice }\end{array}$ & $\begin{array}{l}2.5,5,7.5 \text { and } \\
10 \text { months } \\
\text { of age }\end{array}$ & $\begin{array}{l}\text { - Increased }\left[{ }^{18} \mathrm{~F}\right] \mathrm{GE}-180 \\
\text { SUVr in the cortex from } 5 \\
\mathrm{~m} \text { and the hippocampus } \\
\text { from } 7.5 \mathrm{~m} \text { in Tg mice, } \\
\text { increasing further at } 10 \mathrm{~m} \\
\text { - Similar spatiotemporal pattern } \\
\text { for an increase in } \\
{\left[{ }^{18} \mathrm{~F}\right] \text { florbetaben in Tg mice }} \\
\text { - Correlations between tracer } \\
\text { uptake }\left(\left[{ }^{18} \mathrm{~F}\right] \mathrm{GE}-180 \mathrm{SUVr}\right. \\
\text { and } \\
{\left[{ }^{18} \mathrm{~F}\right] \mathrm{GE}-180 /\left[{ }^{18} \mathrm{~F}\right] \text { florbeta- }} \\
\text { ben ratio) and spatial } \\
\text { learning performance in } \\
\text { the right } \\
\text { entorhinal/piriform cortex } \\
\text { and the right amygdala (NS } \\
\text { in left ROIs) }\end{array}$ & $\begin{array}{l}\text { IHC for fibrillar and } \\
\text { non-fibrillar A } \beta \text { and } \\
\text { neuroinflammation } \\
\text { markers (Iba1, TREM2) } \\
\text { confirmed PET results }\end{array}$ & {$[116$,} \\
\hline \multicolumn{7}{|c|}{ 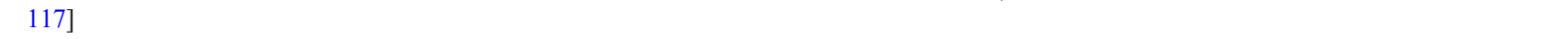 } \\
\hline$\left[{ }^{125} \mathrm{I}\right]-\mathrm{CLINDE}$ & $\begin{array}{l}\text { Investigate the } \\
\text { relationship } \\
\text { between TSPO } \\
\text { and } A \beta \text { load in } \\
\text { AD mice }\end{array}$ & $\begin{array}{l}\text { Female triple } \\
\text { transgenic } \\
(3 \times \mathrm{TgAD}, \\
\mathrm{APP}_{\text {swe }}, \\
\mathrm{PS}_{\mathrm{M} 146 \mathrm{~V}} \text { and } \\
\left.\mathrm{Tau}_{\mathrm{P} 301 \mathrm{~L}}\right) \text { and } \\
\mathrm{C} 57 \mathrm{~B} 1 / 6 \mathrm{~J}-\mathrm{S}- \\
\mathrm{v} 129 \text { control } \\
\text { mice }\end{array}$ & $\begin{array}{l}21 \text { months of } \\
\text { age }\end{array}$ & $\begin{array}{l}\text { - Increase [ }{ }^{125} \text { I]-CLINDE } \\
\text { uptake in TG vs WT mice } \\
\text { - Significant spill over in the } \\
\text { hippocampus from the } \\
\text { nearby ventricular zones } \\
\cdot\left[{ }^{125} \text { I]-CLINDE uptake in the }\right. \\
\text { pituitary, lateral ventricles } \\
\text { and cerebellum is specific } \\
(29.4 \pm 7.6 \text { to } 61 \pm 3.9 \% \\
\text { displacement by the } \\
\text { unlabelled CLINDE) }\end{array}$ & 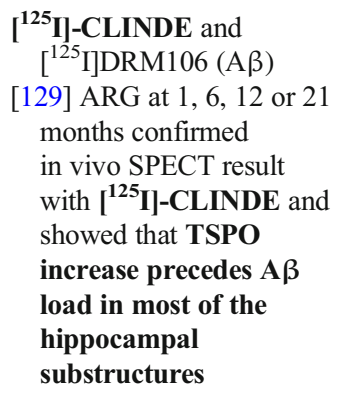 & [124] \\
\hline $\begin{array}{l}{\left[{ }^{11} \mathrm{C}\right]-\mathrm{R}-\mathrm{PK} 11195} \\
{\left[{ }^{11} \mathrm{C}\right] \mathrm{NE} 40(\mathrm{CB} 2)} \\
{[104]}\end{array}$ & $\begin{array}{l}\text { Investigate } \\
\text { microglial status } \\
\text { in brain } \\
\text { senescence }\end{array}$ & $\begin{array}{l}\text { Male SAMP10 } \\
\text { mice }\end{array}$ & $\begin{array}{l}5 \text { and } 15 \text { weeks } \\
\text { of age }\end{array}$ & $\begin{array}{l}\text { - No change in } \\
{\left[{ }^{11} \mathrm{C}\right]-\mathrm{R}-\mathrm{PK} 11195 \text { at any }} \\
\text { ages } \\
\text { - No change in }\left[{ }^{11} \mathrm{C}\right] \mathrm{NE} 40 \\
\text { SUVr at } 5 \text { weeks } \\
\cdot\left[{ }^{11} \mathrm{C}\right] \mathrm{NE} 40 \text { SUVr }> \\
{\left[{ }^{11} \mathrm{C}\right]-\mathrm{R}-\mathrm{PK} 11195 \mathrm{SUVr} \text { at }} \\
15 \text { weeks }\end{array}$ & $\begin{array}{l}\text { - Increase in } \mathrm{CB} 2 / \mathrm{Iba}^{+} \\
\text {cells at } 15 \text { weeks } \\
\text { suggesting an } \\
\text { anti-inflammatory } \\
\text { phenotype } \\
\text { - TSPO IHC consistent with } \\
\text { low/basal level TSPO } \\
\text { expression measured by } \\
\text { PET }\end{array}$ & [123] \\
\hline$\left[{ }^{18} \mathrm{~F}\right] \mathrm{FEPPA}$ & $\begin{array}{l}\text { Test the ability of } \\
\text { TSPO to detect } \\
\text { MHCII }^{+} \\
\text {microglia in WM } \\
\text { in a rat model of } \\
\text { AD }\end{array}$ & $\begin{array}{l}\text { F344 and } \\
\text { TgAPP21 rats }\end{array}$ & $\begin{array}{l}11-14 \text { months } \\
\text { of age }\end{array}$ & $\begin{array}{l}\text { - No significant increase in } \\
{ }^{18} \text { F]FEPPA SUVr in } \\
\text { previously reported [121] } \\
\text { WM MHCII }{ }^{+} \text {microglia in } \\
\text { TgAPP21 rats }\end{array}$ & & {$[122$,} \\
\hline \multicolumn{7}{|l|}{ 86] } \\
\hline$\left[{ }^{18} \mathrm{~F}\right] \mathrm{DPA}-714$ & $\begin{array}{l}\text { In vivo assessment } \\
\text { of } \\
\text { neuroinflamma- } \\
\text { tion in AD mice }\end{array}$ & $\begin{array}{l}\mathrm{B} 6 . \mathrm{Cg}-\mathrm{Tg}\left(\mathrm{APP}_{\mathrm{swe}},\right. \\
\left.\text { PSEN1 } 1_{\mathrm{dE9}}\right) \\
\text { 85Dbo/Mmjax } \\
\text { and WT mice }\end{array}$ & $\begin{array}{l}\text { 6-7, 9-10, } \\
\text { 12-13, and } \\
15-16 \\
\text { months of } \\
\text { age }\end{array}$ & $\begin{array}{l}\text { - No TG vs WT differences at } \\
\text { 6-7 and 9-10 months } \\
\text { - Increase in cortical }(+40 \%) \\
\text { and hippocampal }(+60 \%)\end{array}$ & $\begin{array}{l}\text { IHC for Ibal and TSPO } \\
\text { confirmed and correlated } \\
\text { with PET data }\end{array}$ & [120] \\
\hline
\end{tabular}


Table 4 (continued)

\begin{tabular}{|c|c|c|c|c|c|c|}
\hline PET tracer $*$ & Rational & AD model & $\begin{array}{l}\text { Imaging time } \\
\text { points }\end{array}$ & Main imaging findings & Additional readouts & Ref. \\
\hline$\left[{ }^{18} \mathrm{~F}\right] \mathrm{F}-\mathrm{DPA}$ & $\begin{array}{l}\text { Establish the impact } \\
\text { of low molar } \\
\text { activity tracer on } \\
\text { specific brain } \\
\text { uptake }\end{array}$ & $\begin{array}{c}\text { Males and females } \\
\text { TG APP/PS1-21 } \\
\text { and WT mice }\end{array}$ & $\begin{array}{l}9 \text { months of } \\
\text { age }\end{array}$ & $\begin{array}{l}{\left[{ }^{18} \mathrm{~F}\right] \mathrm{DPA}-714 \text { SUVr at }} \\
12-13 \text { and } 15-16 \text { months } \\
\text { - Significant increase in tracer } \\
\text { SUVr in TG vs WT in more } \\
\text { brain ROIs with high molar } \\
\text { activity }\left[{ }^{18} \mathrm{~F}\right] \mathrm{F}-\mathrm{DPA} \\
\cdot \text { High molar activity tracer } \\
\text { produced greater }(1.5 \mathrm{x}) \\
\text { differences between TG } \\
\text { and WT }\end{array}$ & $\begin{array}{l}\text { - ARG confirmed the TG vs } \\
\text { WT differences in all } \\
\text { brain ROIs } \\
\text { - Significant differences } \\
\text { between low and high } \\
\text { molar activity uptake in } \\
\text { TG }\end{array}$ & [115] \\
\hline
\end{tabular}

*TSPO-PET tracers and associated results are in bold.

Abbreviations: $A R G$, autoradiography; $C B F$, cerebral blood flow; $C B 2$, cannabinoid type 2 receptor; IHC, immunohistochemistry; $N D$, neurodegeneration; NS, non-significant; ROI, region of interest; SAMP10, senescence-accelerated mouse prone 10; SUVr, standard uptake value ratio; system; $T G$, transgenic; $W T$, wild type

$\mathrm{AD}$ animal models need to be aged and are consequently expensive to breed and maintain. In such models and despite its cost, in vivo imaging presents the advantages of reducing the number of animals while increasing statistical power through a longitudinal (i.e. repeated) analysis of the same cohort of animals.

In a rather unusual study, Liu et al. used $\left[{ }^{18} \mathrm{~F}\right] \mathrm{GE}-180 \mathrm{PET}$ to investigate the effect of space radiation on normal brain ageing and on AD between 3.5 and 5 months of age in mice. They found that irradiation had only a very limited effect on brain inflammation, with only a minute reduction in $\left[{ }^{18} \mathrm{~F}\right] \mathrm{GE}$ 180 uptake in female TG vs nonirradiated mice, no such effect was observed in male mice.

Keller et al. [115] reported the only paper that used the APP/PS1-21 model at 9 months of age to test a new TSPO ligand. In this paper, they wanted to evaluate the impact of low vs high molar activity of $\left[{ }^{18} \mathrm{~F}\right] \mathrm{F}-\mathrm{DPA}$ on brain uptake. This is a relevant technical point to all preclinical PET studies. The molar activity of a tracer should not be neglected when performing PET imaging in small animals such as mice which have a small body weight and blood volume because the presence of a too high concentration of cold ligand (i.e. low molar activity) is more likely to impact the binding and may lead to a poor sensitivity of the measures to pathological changes. In this study, they reported a significant 1.5 -fold difference in brain uptake in favour of the high molecular activity. However, it must be noted that in this article, the difference between the low and the high molar activity was particularly large (about 100-fold; $2.25 \pm 0.96 \mathrm{GBq} / \mathrm{mmol}$ vs $260 \pm 110$ $\mathrm{GBq} / \mathrm{mmol}$ ), which is an extreme case scenario.

Most of the other studies reviewed here were trying to characterize and understand the temporal and anatomical pattern of neuroinflammation in various models of AD. Sacher et al. [116] and Biechele et al. [117] monitored neuroinflammation in the new App ${ }^{\text {NL-G-F }}$ model of AD in mice together with $A \beta$ with $\left[{ }^{18} \mathrm{~F}\right]$ florbetaben. In this model, $\left[{ }^{18} \mathrm{~F}\right] \mathrm{GE}-180 \mathrm{TSPO}$ and $\mathrm{A} \beta$ levels started to increase at 5 months of age and continue to further increase up to 10 months of age, earlier than in other models such as the $\mathrm{APP}_{\mathrm{swe}} \times \mathrm{PS}_{\Delta \mathrm{E} 9}[118,119]$, suggesting a rather aggressive AD-like phenotype. In agreement with these previous reports $[118,119]$, Hu et al. [120] reported no changes in $\left[{ }^{18} \mathrm{~F}\right] \mathrm{DPA}-$ 714 uptake in $\mathrm{APP}_{\mathrm{swe}} \times \mathrm{PS}_{\triangle \mathrm{E} 9}$ mice between 6 and 10 months of age with an increase in $\left[{ }^{18} \mathrm{~F}\right] \mathrm{DPA}-714$ SUVr becoming significant at 12 and 16 months of age.

Now trying to understand the meaning of TSPO signal or lack of it, Al-Khishman et al. [86] tried to determine the sensitivity of PET imaging to detect MHCII+ microglial cells as they did in a model of stroke (see above). Using the TgAPP21 transgenic rat model of $\mathrm{AD}$ and $\left[{ }^{18} \mathrm{~F}\right] \mathrm{FEPPA}$ PET, they showed no significant increase in $\left[{ }^{18} \mathrm{~F}\right] \mathrm{FEPPA}$ PET uptake in the TgAPP21 rats vs WT at 11-14 months of age, despite the same group demonstrating the presence of $\mathrm{MHCII}+$ cells in previous reports $[121,122]$. This observation confirms the one made in the stroke model [86] that TSPO-PET is not able or sensitive enough to detect all phenotypes of activated microglia.

Although related to AD, Yamagishi et al. [123] tried to address the slightly different question of the microglial status during brain senescence using a dual tracer study with $\left[{ }^{11} \mathrm{C}\right]-$ R-PK11195 for TSPO imaging and $\left[{ }^{11} \mathrm{C}\right] \mathrm{NE}-40$ for CB2 imaging in 5- and 15-weeks-old SAMP mice. In this study, the authors showed no TSPO expression at all ages but an increase in CB2 binding and expression at 15 weeks of age 
compatible with an anti-inflammatory phenotype of the microglia.

Finally, and although the in vivo imaging performed by Tournier et al. [124] is restricted to only 1 time point (21 months old) in the $3 \times \mathrm{Tg}$ mouse model of $\mathrm{AD}$ with $\left[{ }^{125} \mathrm{I}\right]$ CLINDE, the authors interestingly showed a significant spill over signal in the hippocampus due to significant tracer uptake in the ventricles/choroid plexus. Interestingly, this observation highlights the difficulty to perform accurate quantitative in vivo imaging studies in mouse models of $\mathrm{AD}$ due to the small size of the mouse brain, also highlighting the importance of selecting fairly large ROIs (such as the whole cortex or whole hippocampus) to limit the impact of partial volume effects in mice brain imaging quantification. This is further illustrated by the fact that the dual autoradiography $\left[{ }^{125} \mathrm{I}\right] \mathrm{CLINDE} /\left[{ }^{125} \mathrm{I}\right] \mathrm{DRM} 106(\mathrm{~A} \beta)$ allowed Tournier et al. [124] to demonstrate that increase in TSPO binding (from 6 months in the subiculum) preceded $A \beta$ increase and that these increases affected various part of the hippocampus differentially (subiculum then antero-dorsal and dorsal hippocampus and finally ventral hippocampus).

\section{Parkinson's disease}

In 1988, McGeer and colleagues reported for the first time the presence of reactive microglia in the brains of Parkinson's disease (PD) patients [130]. They suggested what is now generally achieved that the immune system plays an active role and that neuroinflammation is not just a consequence of the ongoing neurodegeneration $[131,132]$. Nevertheless, the interplay between cytokines, neurodegeneration, and protein aggregation as cause or consequence remains largely unknown today $[133,134,131]$. Over the last two decades, neuroinflammation in PD has been a strongly growing research area, but only few TSPO-PET studies [135-138] or TSPOautoradiography [139-141] studies have been reported in preclinical models. In addition, these studies generally report on the feasibility of monitoring brain inflammation but less on the mechanistic of neuroinflammation in PD. Recently, Belloli and colleagues [142] have provided a detailed overview of translational imaging studies in PD, including TSPOPET imaging; complementary to this review, we only focus on TSPO-PET and autoradiography studies in preclinical models of PD. We used the following search in PubMed, “(omega* OR TSPO OR PBR OR PK11195) AND (PET OR positron) AND (brain OR cereb*) AND (Parkinson OR Parkinson's disease OR synuclein) AND (rat OR mouse OR mice OR animal* OR experimental OR pig OR gerbil OR rabbit OR guinea OR primate OR dog OR cat) AND (English[ lang])", which returned initially 16 records, of which only 6 references referred to TSPO-PET imaging studies in preclinical models. An overview of TSPO-PET in preclinical PD models is shown in Table 5.
One of the most gold standard models of PD consists of the intracerebral injection of 6-hydoxydopamine (6-OHDA) - in the substantia nigra (SN), medial forebrain bundle ( $\mathrm{mfb}$ ), or striatum (STR) - which leads to dose-dependent progressive neurodegeneration and transient neuroinflammation [140, 141, 143, 144]. Cichetti et al. described the time course of tyrosine hydroxylase $\left(\mathrm{TH}^{+}\right)$cell loss in parallel to microglial activation up to 30 days post-striatal lesion $(24 \mu \mathrm{g})$ and demonstrated dramatic increase in TSPO signal in ventral mesencephalon and striatum 21 days after 6-OHDA lesioning using $\left[{ }^{11} \mathrm{C}\right]-\mathrm{R}-\mathrm{PK} 11195$ [144]. Maia et al. further developed this work by measuring the time course of the neuroinflammatory response in STR and SN using in vitro binding of $\left[{ }^{3} \mathrm{H}\right]-\mathrm{R}$ PK11195 and ex vivo uptake of $\left[{ }^{123}\right]$ CLINDE, in parallel to changes in dopamine transporter (DAT) binding and $\mathrm{TH}^{+}$ protein levels after 6-OHDA-induced striatal lesion $(10 \mu \mathrm{g})$ [140]. The TSPO binding in STR peaked 7 days post 6OHDA induction and then declined progressively at 4 weeks, until disappearing at 8 weeks post-injection. In the $\mathrm{SN}$, a delayed but similar response was observed with maximal TSPO binding at 14 days post-injection. The neuroinflammatory response as measured with TSPO ligands occurred concomitantly with a progressive loss in $\mathrm{TH}^{+}$cells and DAT; however, in this study, it was not identified which glial cell type was TSPO positive. Noteworthy, the same group [141] recently draw a complete metabolomics, neurodegenerative and neuroinflammatory picture of a new variation of the 6OHDA model (triple striatal injection, $12 \mu \mathrm{g}$ ) through the combination of multiple techniques, amongst which autoradiography using $\left[{ }^{3} \mathrm{H}\right] \mathrm{FPA} 714$. In the search for new radioligands more specific for the microglial response, Crabbé and colleagues used the acute transient neuroinflammation of the 6-OHDA model (striatal induction, $24 \mu \mathrm{g}$ ) to compare a new microglial-specific PET ligand targeting the P2YX7 receptor, $\left[{ }^{11} \mathrm{C}\right] \mathrm{JNJ} 717$, with the well-validated TSPO ligand $\left[{ }^{18} \mathrm{~F}\right] \mathrm{DPA}-714$ [139]. Their TSPO autoradiography study revealed a comparable striatal and nigral TSPO binding pattern as initially described by Maia and colleagues [140]. Surprisingly, the binding of the microglial-specific ligand showed a different temporal pattern than the one observed with the TSPO ligand $\left[{ }^{18} \mathrm{~F}\right] \mathrm{DPA} 714$ [139]. In the striatum, the microglial response was detectable at 7 days, but maximal around 14 days post-injection, in contrast to the TSPO response which was maximal at 7 days. In the $\mathrm{SN}$, an acute microglial response was observed at 7 days, which was observed until 28 days after injection with TSPO-PET ligand [139]. In a 6-OHDA mouse model $(2 \mu \mathrm{lof} 5 \mathrm{mg} / \mathrm{kg}$ in the $\mathrm{SN})$, Fricke et al. transduced cells in the subventricular zone with a lentivirus encoding for firefly luciferase to follow the migration of progenitor as a response to neurodegeneration induced neuroinflammation, which was imaged with $\left[{ }^{18}\right.$ F]DPA714 [145]. Finally, Nomura et al. showed that LPS-induced peripheral inflammation exacerbated the 


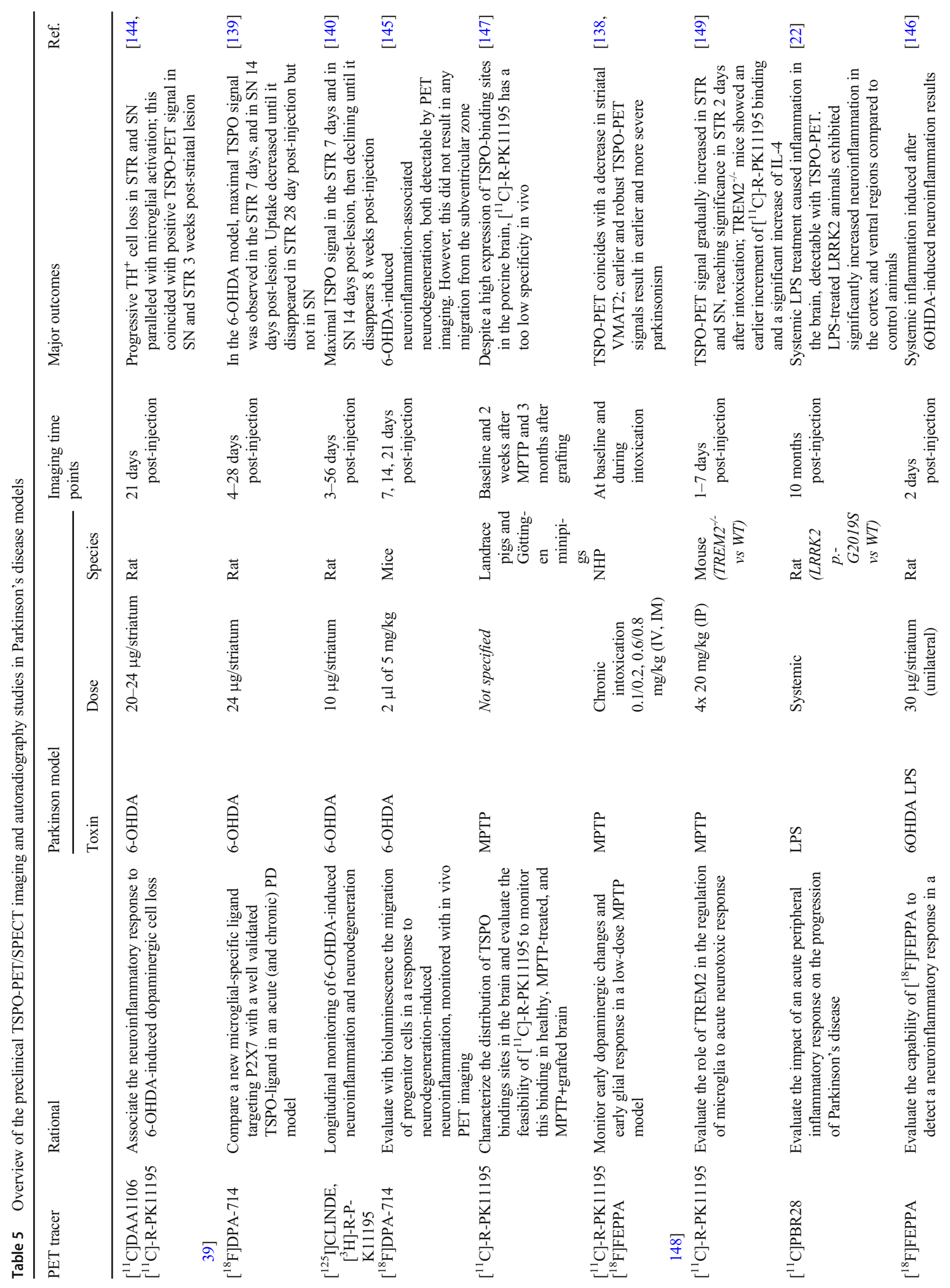




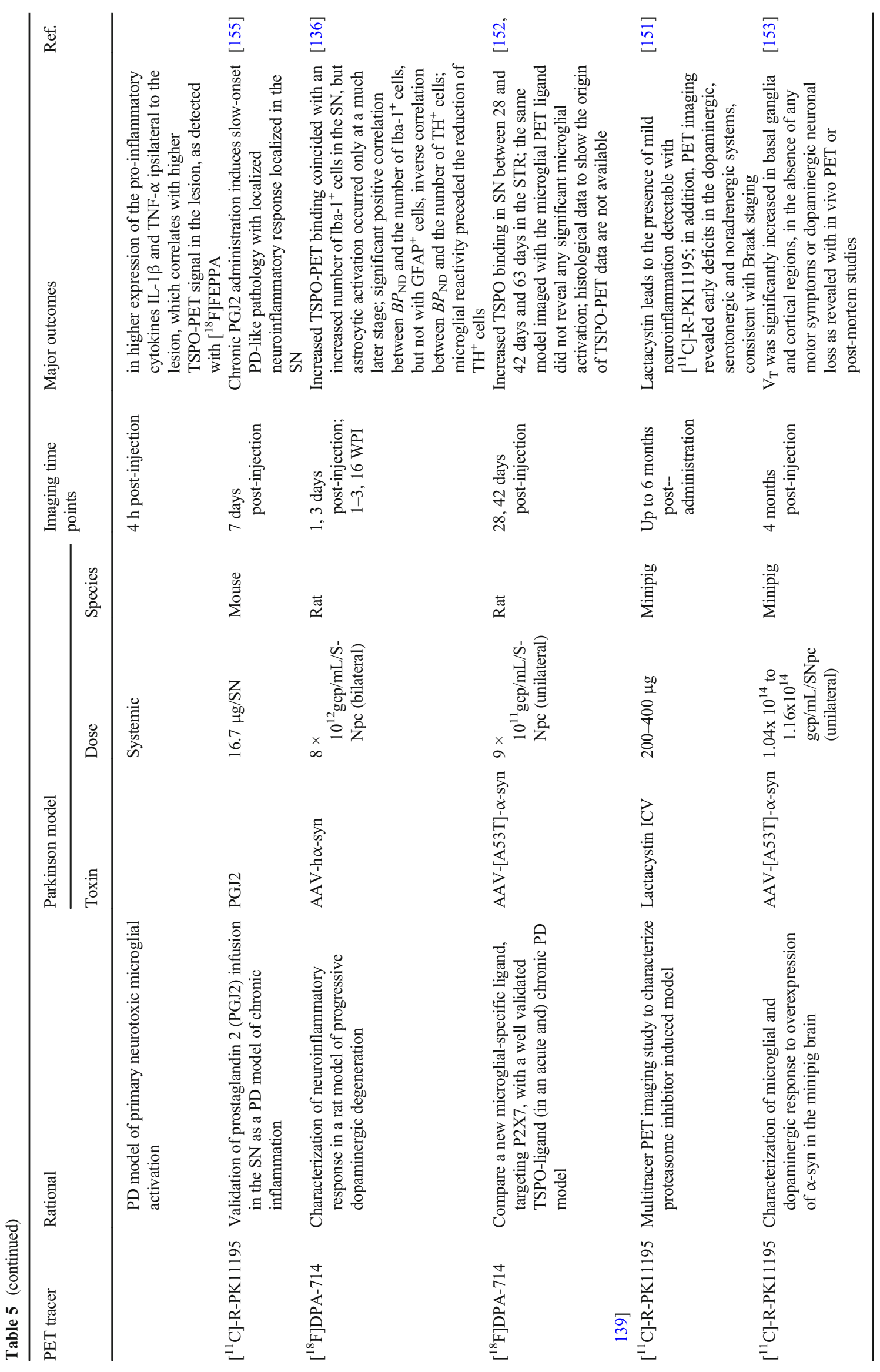


neuroinflammatory response to 6-OHDA. 6-OHDA lesioned animals treated with LPS showed higher expressions of proinflammatory cytokines at the site of the lesion, which was correlated with an increased TSPO-PET signal [146]. In conclusion, the 6-OHDA induces neuroinflammation-associated neurodegeneration, even though the neuroinflammatory reaction should rather be considered as acute, which is not representative of the slow chronic evolution of PD.

The lipophilic compound 1-methyl-4-phenyl-1,2,3,6tetrahydropyridine (MPTP), after crossing the blood-brain barrier, is metabolized by astrocytes. The metabolite, MPP+, is transported into dopaminergic neurons through the DAT where it accumulates and causes toxicity through binding at the mitochondrial complex I. The first PET imaging study on this model was performed on the porcine brain by Cumming et al. who first identified the cerebral distribution and saturation parameters of TSPO binding sites (at that time still referred to as PBBS) by a quantitative $\left[{ }^{3} \mathrm{H}\right] \mathrm{PK} 1195$ binding study. Subsequent in vivo PET imaging with $\left[{ }^{11} \mathrm{C}\right]-\mathrm{R}$ PK11195 was not successful in Landrace pigs despite the high presence of TSPO-binding sites; in Göttingen minipigs, a displaceable signal was detected, which tended to increase 2 weeks after MPTP treatment. Overall, they concluded that $\left[{ }^{11} \mathrm{C}\right]-\mathrm{R}-\mathrm{PK} 11195$ has a too low specificity to detect TSPObinding sites in the porcine brain [147]. Chen et al. evaluated in the NHP, the time course of dopaminergic neuronal changes and neuroinflammation after chronic MPTP intoxication. In this parkinsonian model, they reported a transient increase in TSPO-PET uptake, measured by $\left[{ }^{11} \mathrm{C}\right]-\mathrm{R}-\mathrm{PK} 11195$, which coincided with a decrease in striatal vesicular monoamine transporter type 2 (VMAT2) binding before any decrease in DAT binding was observed [138]. Another study, also in the NHP MPTP model, reported on the neuroinflammatory response in relation to gender, neuroinflammatory cytokines and gut microbiota. It was shown that early and robust $\left[{ }^{18} \mathrm{~F}\right]$ FEPPA PET signals coincided with earlier and more severe parkinsonism, which were especially seen in male compared to female NHP [148]. MPTP-induced neuroinflammation has further been applied in TREM2-deficient mice, using $\left[{ }^{11} \mathrm{C}\right]-\mathrm{R}-\mathrm{PK} 11195$, to demonstrate a central role of TREM2 in the regulation of microglial response to acute neurotoxic insults. Additionally, these data suggested a potential modulatory role of TSPO in response to immune system deficit [149].

Proteasomal inhibitors, such as lactacystin, cause dosedependent dopaminergic neurodegeneration and are an alternative approach to model PD. In this context, a recently developed minipig parkinsonian model [150] has been evaluated in a multitracer PET study to investigate the longitudinal effect of chronic intracerebroventricular (ICV) exposure on monoaminergic projections and neuroinflammation, as evaluated with $\left[{ }^{11} \mathrm{C}\right]-\mathrm{PK} 11195$ [151]. The results of this promising study showed that this model might better reflect early mechanisms in Parkinson's disease pathology.
Transgenic or viral vector-induced models allow the following-up of neuroinflammation alongside progressive neurodegeneration. Rodriguez and colleagues characterized, in a humanized $\alpha$-synuclein associated adenoviral vector-induced (AAV-h $\alpha$-syn) rat model, the neuroinflammatory response in the SN using a longitudinal follow-up study. They showed that increased TSPO-PET binding measured with $\left[{ }^{18} \mathrm{~F}\right] \mathrm{DPA}-714$ coincided with an increased number of Iba- $1^{+}$cells in the $\mathrm{SN}$, while astrocytic activation occurred only at a much later stage. A significant correlation was shown between $\left[{ }^{18} \mathrm{~F}\right] \mathrm{DPA}-714 \mathrm{BP}_{\mathrm{ND}}$ and the number of Iba- ${ }^{+}$cells, but not with $\mathrm{GFAP}^{+}$cells. Interestingly, the microglial reactivity preceded the reduction of $\mathrm{TH}^{+}$cells, and over time, $\left[{ }^{18} \mathrm{~F}\right] \mathrm{DPA}-714 \mathrm{BP}_{\mathrm{ND}}$ was inversely correlated to the number of $\mathrm{TH}^{+}$cells [136]. Surprisingly, in this model, the P2X7R tracer $\left[{ }^{11} \mathrm{C}\right] \mathrm{JNJ} 717$ was not able to detect any microglial response [139, 152]. Unfortunately, no immunohistochemistry data identifying the glial cell type expressing TSPO has been reported. Finally, AAV-induced A53T overexpression in the $\mathrm{SN}$ of the minipig brain induced a significantly higher TSPO-PET uptake in the basal ganglia and cortical areas, as shown with $\left[{ }^{11} \mathrm{C}\right]-\mathrm{R}-\mathrm{PK} 11195$; however, neuroinflammation occurred without any detectable dopaminergic neuronal loss or behavioural deficit [153]. It was suggested that multiple injection sites or different vectors should be tested to improve the transduction of dopaminergic nigral neurons.

Finally, the role of LRRK2 in the immune system underlies one of many hypotheses why LRRK2 p.GS20195S mutation is one of the most common risk factors for PD. As peripheral administered LPS induces a neuroinflammatory response that eventually can lead to specific loss of dopaminergic neurons [15], LPS is an appealing tool to assess the association of peripheral-induced neuroinflammation in the progression of PD. In this context, a longitudinal $\left[{ }^{11} \mathrm{C}\right] \mathrm{PBR} 28$ TSPO-PET study was performed on rats carrying the LRRK2 p.GS20195S mutation and non-transgenic littermates treated peripherally with LPS $(3 \mathrm{mg} / \mathrm{kg}$, i.p.) or vehicle. This study revealed a significant increased TSPO-PET signal in transgenic rats 10 months after systemic LPS challenge compared to saline-treated non-transgenic littermates [22]. Interestingly, these authors calculated age-centred SUV by subtracting the mean SUV of all saline-treated animals from each individual rat's SUV to account for the effect of age on neuroinflammation. This was based on previous work of the same group [154], where they reported on the sensibility of $\left[{ }^{11} \mathrm{C}\right]$ PBR2 8 TSPO-PET to ageing, which might be related to increased microglial activity in the ageing brain. In addition, in this study, the authors validated that the SUV measure is highly correlated with and less variable than the $\mathrm{V}_{\mathrm{T}}$ quantification parameter. 


\section{Huntington disease}

Huntington's disease (HD) is caused by a polymorphic trinucleotide CAG repeat expansion in the HTT gene that encodes the polyglutamine (polyQ) repeat in the $\mathrm{N}$-terminal region of Huntingtin $(\mathrm{Htt})$. These expansion repeats induce neuropathological hallmarks including a substantial accumulation of the $\mathrm{Htt}$ aggregates in the cortex and striatum [156]. These Httaggregated fragments set in motion a complicated cascade of both damaging, compensatory molecular processes and neuroinflammation, which is an important early pathological process of the disease. Activated microglia have been detected in brains from presymptomatic HD carriers [157] to postmortem HD patients [158] together with elevated inflammatory cytokines in both the CNS and plasma from HD patients [159].

Finding from animal models have an important contribution to elucidate pathways that are disrupted and have provided insights into the pathogenesis of this disease, enabling the development of therapeutic strategies [160]. As no spontaneous occurring animal models of HD exists, this pathology is modelled by toxins and viral vectors or through the use of transgenic animals.

The administration of either excitotoxic agents - such as quinolinic acid (QA) - or mitochondrial toxins, such as 3nitropropionic acid (3NP), can replicate some elements of the disease in both rodents $[161,162]$ and non-human primates (NHP) [163-165]. QA is an endogenous NMDA receptor agonist with excitotoxic properties. The excessive activation of NMDA receptors leads to a massive increase of calcium influx in neurons that involves the production and release of free radicals (reactive oxygen and nitrogen species), which can trigger cell oxidative damage leading to neuronal death. This model has been characterized by severe and fast (within $48 \mathrm{~h}$ ) neuronal degeneration (GABAergic medium spiny neurons) as shown by the loss of NeuN staining [166]. Factors released during this degenerative process rapidly induce a proinflammatory environment leading to the activation of surrounding microglial cells and astrocytes [167]. Intracerebral injection of QA results in a reproducible lesion that -when injected in the striatum - reproduces some biochemical, behavioural and pathologic features of HD in rodents and nonhuman primates $[168,169,167,164]$. In the $3 \mathrm{NP}$ (3nitropropionic acid) model, Ramachandran et al. [170] have reported increased mRNA expression of pro-inflammatory markers and of GFAP compared to controls 14 days after toxin administration.

TSPO-PET imaging in HD models has mainly been reported in the QA excitotoxic model since the localized, transient neuroinflammatory lesion facilitates the short-, to mid- and to long-term evaluation of TSPO-PET/SPECT radiotracers. A summary of the TSPO-PET imaging studies in HD is provided in Table 6. In all TSPO-PET/SPECT imaging studies reported, QA was unilaterally injected in the striatum, using the contralateral side as an internal control. All excitotoxic QA models were induced in rodents, except for one study that reported TSPO imaging of $\left[{ }^{18} \mathrm{~F}\right]$-DPA-714 in non-human primates [171]. As such, the QA model has been used either to characterize the properties of new TSPO-PET/SPECT radiotracers $\left(\left[{ }^{125} \mathrm{I}\right]\right.$ CLINDE $[168,172],\left[{ }^{18} \mathrm{~F}\right] \mathrm{DPA}-714[171],\left[{ }^{3} \mathrm{H}\right]-$ PK11195 [173]) or to evaluate therapeutics or TSPO ligands as neuroprotective agents [174, 175]. Furthermore, short- to long-term NI changes post QA lesion were explored in transversal and longitudinal TSPO-PET imaging studies to correlate TSPO expression with glial reactivity in this model [172, 171, 176]. Overall, these studies reported a concomitant increase in TSPO radiotracer binding together with an increase in IHC inflammatory markers in the lesion. Arlicot et al. evaluated the properties of the $\left[{ }^{125} \mathrm{I}\right]$ CLINDE tracer at 6 days post QA injected at different doses [168]: microglial activation in the ipsilateral striatum was clearly observed using immunohistochemical (IHC) staining (OX-42 antibody), and authors evidenced a positive relationship between the intensity of IHC OX-42 staining and the dose of injected QA. Longitudinal TSPO-PET studies up to several months post-injection have also compared the time course of neuroinflammation with neurodegeneration, evaluating additionally the relative contribution of activated microglia and activated astrocytes in TSPO overexpression. Overall, longitudinal studies described a temporal transitory neuronal loss and reactive gliosis in the lesioned striatum. In Arlicot et al., TSPO expression was elevated from day 4 to 30 after QA administration with a maximal $\left[{ }^{125} \mathrm{I}\right]$ CLINDE binding at 4,7 and 14 days post-injection followed by a decline from day 30 down to day 90 [172]. In Lavisse et al., the level of TSPO immunoreactivity markedly increased from day 7 and was maximal between day 21 and day 40 and then decreased in intensity until day 91 [171]. The $\left[{ }^{18} \mathrm{~F}\right]-\mathrm{DPA}-714$ total distribution volume increased initially in the restricted centre of the injection site from day 7 and progressively encompassed a larger area from day 7 to day 21 and remained visible on day 49 . The same spreading observation was reported by Moresco et al. with a parallel increase of $\left[{ }^{11} \mathrm{C}\right]-\mathrm{R}-\mathrm{PK} 11195$ binding and microglial activation (and macrophage infiltration) markers as revealed by OX-42 staining, in both striatal and extrastriatal areas. These increases were maximum 7 days after QA injection, but OX-42 staining disappeared at later time points (30 and 60 days) while $\left[{ }^{11} \mathrm{C}\right]-$ R-PK11195 binding was still increased although in the restricted lesioned area. This observation led to hypothesize the presence of reactive astrocytes as $\left[{ }^{11} \mathrm{C}\right]-\mathrm{R}-\mathrm{PK} 11195$ presumably binds also to this cell type [177].

In some of these longitudinal studies, the astroglial and microglial activation, in parallel to neuronal loss, was characterized at several time points from 1 to $60-90$ days post-QA injection, by double or triple immunostaining with GFAP, OX-42, Iba1 or CD68 and TSPO antibody. Moresco et al. 
Table 6 Overview of the preclinical TSPO-PET/SPECT imaging studies in Huntington's disease models

\begin{tabular}{|c|c|c|c|c|c|c|}
\hline $\begin{array}{l}\mathrm{PET} / \mathrm{SPECT} \\
\text { tracer }\end{array}$ & Rational & $\begin{array}{l}\text { HD model } \\
\text { and species }\end{array}$ & $\begin{array}{l}\text { Imaging time } \\
\text { points }\end{array}$ & Main imaging findings & Additional readouts & Ref. \\
\hline$\left.{ }^{25} \mathrm{I}\right] \mathrm{CLINDE}$ & $\begin{array}{l}\text { Characterization and } \\
\text { validation of the tracer } \\
\text { at different stages of } \\
\text { excitotoxic lesion }\end{array}$ & $\begin{array}{l}\text { QA }(*) ; 75, \\
150, \\
300 \text { nmol } \\
\text { in male } \\
\text { Wistar } \\
\text { rats }\end{array}$ & $\begin{array}{l}6 \text { days } \\
\text { post-- } \\
\text { injection }\end{array}$ & $\begin{array}{l}\text { - Specificity confirmed with } \\
\text { PK1195 blocking studies } \\
(-82 \% \text { decrease }) \text {. } \\
\text { - Significant }\left[{ }^{125} \mathrm{I}\right] \text { CLINDE } \\
\text { uptake increase in } \\
\text { lesioned compared to } \\
\text { intact side }\end{array}$ & $\begin{array}{l}\text { Autoradiographic analysis } \\
\text { (including blocking) and IHC } \\
\text { confirmed in vivo results }\end{array}$ & [168] \\
\hline$\left[{ }^{125} \mathrm{I}\right] \mathrm{CLINDE}$ & $\begin{array}{l}\text { Investigation of } \\
\text { the spatial and temporal } \\
\text { density of TSPO after } \\
\text { excitotoxic lesion }\end{array}$ & $\begin{array}{l}\text { QA }(*) \\
150 \text { nmol } \\
\text { in male } \\
\text { Wistar } \\
\text { rats }\end{array}$ & $\begin{array}{l}1,7,14,60 \\
\text { and } 90 \text { days } \\
\text { post-- } \\
\text { injection }\end{array}$ & $\begin{array}{l}\text { - Uptake sign increased in } \\
\text { the lesioned striatum from } \\
1 \text { to } 60 \text { days } \\
\text { - Uptake increase until day } 4 \\
\text { and plateau at 4-30 days. } \\
\text { - Progressive decrease at } \\
\text { 30-90 days }\end{array}$ & $\begin{array}{l}\text { Autoradiography of TSPO } \\
\text { expression corresponded to the } \\
\text { temporal profile of both } \\
\text { microglial activation and } \\
\text { astrogliosis. } \\
\text { Maximal astrocytic response at } \\
7-14 \text { days and at } 14 \text { days for } \\
\text { microglia }\end{array}$ & [172] \\
\hline$\left[{ }^{11} \mathrm{C}\right]-\mathrm{R}-\mathrm{PK} 11195$ & $\begin{array}{l}\text { Combination of in vivo, } \\
\text { ex vivo and IHC } \\
\text { approaches to analyse } \\
\text { both short- and } \\
\text { long-term changes in } \\
\text { the QA model }\end{array}$ & $\begin{array}{l}\text { QA }(*) \\
210 \mathrm{nmol} \\
\text { in Wistar } \\
\text { rats }\end{array}$ & $\begin{array}{l}8,30 \text { and } 60 \\
\text { days } \\
\text { post-- } \\
\text { injection } 30 \\
\text { and } 60 \text { days } \\
\text { post-- } \\
\text { injection }\end{array}$ & $\begin{array}{l}\text { At } 8,30 \text { and } 60 \text { days, } \\
{\left[{ }^{11} \mathrm{C}\right]-\mathrm{R}-\mathrm{PK} 11195} \\
\text { binding values are found } \\
\text { to be } 3.4,3.0 \text { and } 2.8 \\
\text { times higher than those of } \\
\text { the control }\end{array}$ & $\begin{array}{l}\text { Reduction of both A2A and } \\
\text { dopamine D2 receptors together } \\
\text { with an augmentation of } \\
\text { microglial } \\
\text { activation/macrophage } \\
\text { infiltration both in the lesioned } \\
\text { striatum and, to some degree, } \\
\text { also in extrastriatal areas }\end{array}$ & [176] \\
\hline$\left[{ }^{18} \mathrm{~F}\right] \mathrm{DPA}-714$ & $\begin{array}{l}\text { Pharmacological } \\
\text { Characterization of the } \\
\text { tracer and evaluation of } \\
\text { the cellular contribution } \\
\text { to the PET signal }\end{array}$ & $\begin{array}{l}\text { QA }(*) \\
180 \text { nmol } \\
\text { in } \\
\text { cynomol- } \\
\text { gus NHP }\end{array}$ & $\begin{array}{l}\text { 7, } 21,4090 \\
\quad \text { days } \\
\text { post-- } \\
\text { injection }\end{array}$ & $\begin{array}{l}-\mathrm{VT}:+17 \%,+54 \%,+157 \% \\
\text { and }+39 \% \text { higher than } \\
\text { baseline on days } 7,14,21 \\
\text { and } 91 . \\
\text { - Decrease of uptake }(-73 \%) \\
\text { in the lesioned striatum } \\
\text { after blockage with } \\
\text { PK11195 }\end{array}$ & $\begin{array}{l}\text { IHC demonstrated progressive } \\
\text { microglial activation from day } \\
2 \text { followed by delayed } \\
\text { astrocytic reaction reaching } \\
\text { maximum between } 7 \text { and } 14 \\
\text { days. High correlation with } \\
\text { in vivo results }\left(r^{2}=0.98\right)\end{array}$ & [171] \\
\hline$\left[{ }^{18} \mathrm{~F}\right] \mathrm{PBR} 06$ & $\begin{array}{l}\text { Evaluation of the } \\
\text { feasibility to detect } \\
\text { activated microglia in } \\
\text { these models }\end{array}$ & $\begin{array}{l}\mathrm{R} 6 / 2 \\
\quad \mathrm{BACHD} \\
\text { transgenic } \\
\text { mice }\end{array}$ & $\begin{array}{l}\text { Early, mid- } \\
\quad \text { and } \\
\text { advanced } \\
\text { stages }\end{array}$ & $\begin{array}{l}\text { In R6/2 mice (advanced } \\
\text { stage): } \\
\text { - }\left[{ }^{18} \text { F]PBR06 accumulation }\right. \\
\text { in each ROI significantly } \\
\text { higher by } 25-30 \% \\
\text { compared with WTs } \\
\text { - Reduction of } 39-45 \% \text { of } \\
\text { uptake after blocking with } \\
\text { PK11195 } \\
\text { - Elevated }\left[{ }^{18} \mathrm{~F}\right] \mathrm{PBR} 06 \\
\text { uptake in BACHD mice } \\
\text { (early stage) compared } \\
\text { with WTs in each ROI }\end{array}$ & $\begin{array}{l}\text { TSPO expression correlated to } \\
\text { microglial activation (increased } \\
\text { IBA-1) and increased striatal } \\
\text { levels of pro-inflammatory } \\
\text { cytokines (IL-6 and TNFa) }\end{array}$ & [187] \\
\hline
\end{tabular}

used complementary autoradiography and confocal laserscanning microscopy techniques to explore striatal and extrastriatal changes after QA injection with a finer analysis of cellular and subcellular events triggered by QA injection [176]. The time course of $\left[{ }^{125} \mathrm{I}\right]$-CLINDE binding matched with the temporal profile of both microglial and astrocyte reaction in Arlicot et al. study [172]: increased staining of GFAP-immunoreactive astrocytes was maximal at days 7 and 14 while microglial IHC marker peaked at day 14. They both then significantly decreased at days 60 and 90. Since $\left[{ }^{125} \mathrm{I}\right]$-CLINDE binding followed the same temporal profile and co-localized in autoradiographic slices, authors concluded that both reactive astrocytes and microglia contributed to TSPO expression and signal. These observations were not in agreement with the results observed by Ryu and colleagues who reported that TSPO was primarily expressed in immunoreactive microglia and weakly in GFAP immunoreactive astrocytes, $24 \mathrm{~h}$ after QA injection [175]. This discrepancy could be partly explained by the different dose of injected QA used in these two studies (150 and $60 \mathrm{nmol}$ in Arlicot et al. and Ryu et al., respectively) and the early time of imaging as astrogliosis has been reported to occur at later stages after 
lesion. Moreover, intrastriatal QA lesion in the NHP has shown to induce progressive microglial activation from day 2 (Iba-1 labelling) with a delayed astrocytic reaction reaching maximal expression at 7 and 14 days [171]. The activated microglia were detected in the core of the lesion area whereas cell bodies of reactive astrocytes were organized as a perilesional rim with long and straight processes entering the lesion core from the periphery, as previously reported in rats [178]. Triple immunostaining studies (TSPO, GFAP and CD68 antibodies) provided further evidence that the $\left[{ }^{18} \mathrm{~F}\right] \mathrm{DPA}-714$ PET signal primarily originated from activated microglia in this model (TSPO and CD68 staining colocalization) although it had previously been noted that this TSPO radiotracer binds to reactive astrocytes in a model of selective astrocytes reactivity [179]. Indeed, reactive astrocytes are known to be molecularly and functionally heterogeneous and their molecular profile can depend on the induceddisease context, the disease stage or the considered brain region [180].

Neurotoxin models were developed before the discovery of the Htt genetic mutation. The identification of the genetic mutation in HD led to the generation of a variety of animal models that express different forms of mutant huntingtin (expression of either full-length or $\mathrm{N}$-terminal fragments of mutant $\mathrm{Htt}$ ) showing different pathological spectra of the disease [181]. For example, the R6/2 mouse model carrying an N-terminal exon 1 fragment of the disease-causing human HTT gene displays physiological and behavioural phenotypes including progressive weight loss, shortened life span, progressive motor dysfunction and cognitive decline $[182,183]$. A wide range of gene dysregulations has been reported in various brain regions of R6/ 2 mice including the expression of multiple inflammation- and stress-related genes as well as genes related to neurodegeneration [184]. In the brain of the R6/2 mouse model, significantly elevated pro-inflammatory cytokines were detected such as interleukin 6 (IL-6) and tumour necrosis factor alpha (TNF $\alpha$ ) [185]. At early disease stages, microglia have been shown to be abnormal through ferritin accumulation and Ibal immunostaining, and these abnormalities correlated with disease severity [186]. However, to the best of our knowledge, only one TSPO imaging study in transgenic models has been reported yet. In two HD mouse models, Simmons et al. assessed the feasibility of utilizing TSPO-PET imaging with the $\left[{ }^{18} \mathrm{~F}\right]$ PBR06 ligand to detect activated gliosis [187]. $\left[{ }^{18} \mathrm{~F}\right]-\mathrm{PBR} 06$ revealed microglial activation at a late disease stage in R6/2 mice, and at early to mid-stage in symptomatic BACHD mice. The $\left[{ }^{18} \mathrm{~F}\right]$-PBR06 TSPO-PET signal was correlated with increased Iba-1 and TSPO IHC staining in both models, and correlation was particularly strong in the striatum, cortex and hippocampus while GFAP levels did not correlate with $\left[{ }^{18} \mathrm{~F}\right]$ PBR06 uptake. These results indicated that TSPO seems to be predominately expressed on activated microglia in the brain in these transgenic models.
$(*)$, unilaterally injected in the striatum; $I H C$, immunohistochemistry; WT, wild type

\section{Models of multiple sclerosis}

The PubMed search used for this paragraph was "(omega* OR TSPO OR PBR OR PK11195) AND (PET OR positron) AND (brain OR cereb*) AND (multiple AND sclerosis) AND (rat OR mouse OR mice OR animal* OR experimental OR pig OR gerbil OR rabbit OR guinea OR model OR dog OR cat) AND (English[ lang])"; it returned 54 references, including 23 reviews; once Molecular Imaging and Contrast Agent Database entries, clinical studies and reviews were excluded, 11 preclinical studies were kept for this review. All these studies are summarized in Table 7.

Various studies investigated the neuroinflammatory profile of different models of MS (EAE or WM lesion) using $\left[{ }^{18} \mathrm{~F}\right]$ PBR $111[188],\left[{ }^{18} \mathrm{~F}\right]$ VC701 [189], $\left[{ }^{18} \mathrm{~F}\right] \mathrm{GE}-180$ [190-192] or $\left[{ }^{18} \mathrm{~F}\right] \mathrm{DPA}-714[193,194]$ PET tracers. Overall, TSPO imaging studies in MS models consistently reported a moderate to large increase in TSPO tracer uptake in the affected brain regions. Using an interesting model of relapsing experimental autoimmune encephalomyelitis (EAE) in mice, Mattner et al. [188] demonstrated a high increase $(+135 \%)$ in $\left[{ }^{18} \mathrm{~F}\right] \mathrm{PBR} 111$ uptake during the 1 st episode before the signal returned to baseline during the 2nd episode and bounced back up during the 3rd episode, demonstrating the interest of using TSPO imaging to monitor different stages of the disease in the preclinical model but with also important implication for translational application. The in vivo PET data were confirmed by IHC, demonstrating that TSPO expression was limited to microglial cells while astrocytes were TSPO negative. Additionally, Nack et al. [190] reported that $\mathrm{TSPO}^{+}$cells were microglia following cuprizone treatment and that supplementing Cuprizone with $\mathrm{MOG}_{35-55}$ peptide immunization drove the recruitment of $\mathrm{TSPO}^{+}$monocytes in the lesion contributing to the overall PET signal on top of resident activated microglia; these results are in agreement with a more recent study with $\left[{ }^{18} \mathrm{~F}\right] \mathrm{DPA} 714$ [194]. Interestingly, Zinnhardt et al. [193] showed using $\left[{ }^{18} \mathrm{~F}\right] \mathrm{DPA} 714$ that during demyelination $\mathrm{TSPO}^{+}$cells consisted only of microglia, while during remyelination, astrocytes also became $\mathrm{TSPO}^{+}$. Using $\left[{ }^{11} \mathrm{C}\right]$-R-PK11195 TSPO-PET as a potential readout for therapeutic intervention, Converse et al. [195] aimed to evaluate the response to minocycline, an antibiotic that also represses microglial activation, in the zymosan-induced WM lesion in rats. They demonstrated an increase in $\left[{ }^{11} \mathrm{C}\right]-\mathrm{R}-\mathrm{PK} 11195$ uptake in the WM lesion that was significantly reduced by minocycline. More recently, Vainio et al. [191] investigated the response to an anti-VLA4 (very late antigen-4 integrin) antibody treatment in an EAE model in rats and demonstrated only a trend to increase in $\left[{ }^{18} \mathrm{~F}\right] \mathrm{GE}-180$ uptake following 2 weeks of treatment but interestingly a rebound in 
Table 7 Overview of the preclinical TSPO imaging studies in models of multiple sclerosis

\begin{tabular}{|c|c|c|c|c|c|c|}
\hline PET tracer * & Rational & MS model and species & Imaging time points & Main imaging findings & Additional readouts & Ref. \\
\hline$\left[{ }^{11} \mathrm{C}\right]-\mathrm{R}-\mathrm{PK} 11195$ & $\begin{array}{l}\text { Advance in vivo } \\
\text { imaging } \\
\text { methodology for } \\
\text { studying } \\
\text { microglial } \\
\text { activation and } \\
\text { therapeutic } \\
\text { response to } \\
\text { minocycline after } \\
\text { WM lesion }\end{array}$ & $\begin{array}{l}\text { Zymosan A stereotaxic } \\
\text { injection in the CC of } \\
\text { female SD rats }(250 \pm 19 \mathrm{~g})\end{array}$ & 7 days post-injection & $\begin{array}{l}\text { - Increased } \\
\left.I^{11} \mathrm{C}\right]-\mathrm{R}-\mathrm{PK} 11195 \\
\text { uptake in the } \\
\text { zymosan-injected } \\
\text { WM } \\
\cdot 46 \% \text { reduction in } \\
\left.{ }^{11} \mathrm{C}\right]-\mathrm{R}-\mathrm{PK} 11195 \\
\text { uptake in the } \\
\text { minocycline-treated } \\
\text { group }\end{array}$ & $\begin{array}{l}\left.{ }^{3} \mathrm{H}\right]-\mathrm{R}-\mathrm{PK} 11195 \mathrm{ARG} \\
\text { confirmed the presence } \\
\text { of NI in the } \\
\text { zymosan-injected WM }\end{array}$ & [195] \\
\hline$\left[{ }^{18} \mathrm{~F}\right] \mathrm{PBR} 111$ & $\begin{array}{l}\text { Investigate } \\
\text { NI at different } \\
\text { phases of EAE }\end{array}$ & $\begin{array}{l}\text { Subcutaneous injection of } \\
\mathrm{PLP}_{139-151} \text { peptide in female } \\
\text { SJL/J mice }\end{array}$ & $\begin{array}{l}\text { Baseline and 6, 13, } \\
20,27,35 \text { and } 41 \\
\text { days } \\
\text { post-- } \\
\text { immunization }\end{array}$ & $\begin{array}{l}\text { - Peak increase (+135 } \\
\pm 20 \%) \text { in } \\
{\left[{ }^{18} \text { F]PBR111 uptake }\right.} \\
\text { in all brain ROIs } \\
\text { after the 1st episode } \\
\text { - Return to baseline } \\
\text { during the } 2 \text { nd } \\
\text { episode } \\
\text { - Significant increase } \\
\text { during the 3rd } \\
\text { episode }\end{array}$ & $\begin{array}{l}\text { IHC for TSPO and F4/80 } \\
\text { and CD } 11 \mathrm{~b} \text { confirmed } \\
\text { the increase in TSPO } \\
\text { expression observed by } \\
\text { PET to be microglial, } \\
\text { GFAP+ cells were } \\
\text { negative for TSPO }\end{array}$ & [188] \\
\hline $\begin{array}{l}{\left[{ }^{11} \mathrm{C}\right]-\mathrm{R}-\mathrm{PK} 11195} \\
{\left[{ }^{11} \mathrm{C}\right] \mathrm{MeDAS}} \\
\text { (myelin) [200] } \\
{\left[{ }^{18} \mathrm{~F}\right] \mathrm{FDG}}\end{array}$ & $\begin{array}{l}\text { Assess the } \\
\text { feasibility of } \\
\text { in vivo } \\
\text { monitoring of } \\
\text { MS-specific } \\
\text { disease processes } \\
\text { with PET }\end{array}$ & $\begin{array}{l}\text { Demyelination by stereotactic } \\
\text { injection of } 1 \% \text { lysolecithin } \\
\text { in the CC and striatum of } \\
\text { male SD rats ( } 8-10 \text { weeks } \\
\text { old) }\end{array}$ & $\begin{array}{l}{\left[{ }^{18} \mathrm{~F}\right] \mathrm{FDG} \text { and }} \\
{\left[{ }^{11} \mathrm{C}\right]-\mathrm{R}-\mathrm{PK} 11195} \\
\text { imaging at } 3 \text { days } \\
\text { and } 1 \text { and } 4 \text { weeks } \\
\text { and }\left[{ }^{11} \mathrm{C}\right] \mathrm{MeDAS} \\
\text { PET at } 1 \text { and } 4 \\
\text { weeks after } \\
\text { injection }\end{array}$ & $\begin{array}{l}\cdot \text { No change in }\left[{ }^{18} \mathrm{~F}\right] \mathrm{FDG} \\
\text { uptake } \\
\cdot+\mathbf{8 4 \%} \text { and }+\mathbf{3 7 \%} \% \text { in } \\
{\left[{ }^{11} \mathrm{C}\right]-\mathrm{R}-\mathrm{PK} 11195} \\
\text { SUV in the lesion and } \\
\text { ipsilateral } \\
\text { hemisphere at } 3 \text { days } \\
\text { and } 1 \text { week, returning } \\
\text { to baseline at } 4 \text { weeks } \\
\text { - Decrease }(-7 \%) \text { in } \\
{\left[{ }^{11} \mathrm{C}\right] \mathrm{MeDAS} \text { SUVr }}\end{array}$ & $\begin{array}{l}\text { - Iba1 IHC confirmed the } \\
\text { increase in NI in the CC } \\
\text { and striatum } 3 \text { days and } \\
1 \text { week post-injection } \\
\text { - }\left[{ }^{11} \mathrm{C}\right] \text { MeDAS ARG } \\
\text { showed a } 57 \% \text { decrease } \\
\text { in myelin binding in } \\
\text { ipsilateral CC } \\
\text { - Myelin IHC confirmed } \\
\text { demyelination at } 3 \text { days } \\
\text { and } 1 \text { week and partial } \\
\text { remyelination at } 4 \\
\text { weeks }\end{array}$ & [198] \\
\hline $\begin{array}{l}{\left[{ }^{11} \mathrm{C}\right]-\mathrm{R}-\mathrm{PK} 11195} \\
{\left[{ }^{18} \mathrm{~F}\right] \mathrm{FDG}} \\
{\left[{ }^{18} \mathrm{~F}\right] \mathrm{FSPG}} \\
\text { (system xc') } \\
{[103]}\end{array}$ & $\begin{array}{l}\text { Better } \\
\text { understanding of } \\
\text { system } \\
\mathrm{xc}^{-} \text {in NI in MS }\end{array}$ & $\begin{array}{l}\text { Subcutaneous injection of } \\
\text { MBP in male Lewis rats ( } 8 \\
\text { weeks old, 200-220 g) }\end{array}$ & $\begin{array}{l}\text { Baseline and at 7,14, } \\
21 \text { and } 28 \text { days } \\
\text { after EAE } \\
\text { induction }\end{array}$ & $\begin{array}{l}\text { - No significant changes } \\
\text { in FDG } \\
\text { - Significant increase in } \\
\text { [ }^{11} \text { C]-R-PK11195 } \\
\text { uptake in the } \\
\text { cerebellum and } \\
\text { cervical and lumbar } \\
\text { spinal cord at } \mathbf{1 4} \text { days } \\
\text { - Significant increase in } \\
{\left[{ }^{18} \text { F]FSPG uptake in }\right.} \\
\text { the lumbar spinal cord } \\
\text { at } 14 \text { days, normalized } \\
\text { by administration of } \\
\text { liposome-encapsulated } \\
\text { clodronate }\end{array}$ & $\begin{array}{l}\text { - Liposome-encapsulated } \\
\text { clodronate treatment } \\
\text { tends to worsen } \\
\text { neurological score but } \\
\text { reduced IHC Iba1 } \\
\text { staining } \\
\text { - Suggest that microglia } \\
\text { are the source of system } \\
\text { xc }^{-} \text {in NI }\end{array}$ & [199] \\
\hline$\left[{ }^{18} \mathrm{~F}\right] \mathrm{VC} 701$ & $\begin{array}{l}\text { Evaluate NI in a } \\
\text { mouse EAE } \\
\text { using TSPO-PET } \\
\text { with }\left[{ }^{18} \mathrm{~F}\right] \mathrm{VC} 701\end{array}$ & $\begin{array}{l}\text { Subcutaneous injection of } \\
\mathrm{MOG}_{35-55} / \mathrm{CFA} \text { and } \\
\text { pertussis toxin in female } \\
\text { C57BL/6J mice (8-12 } \\
\text { weeks old) }\end{array}$ & $\begin{array}{l}14 \text { days after EAE } \\
\text { induction }\end{array}$ & $\begin{array}{l}\text { - Increased }\left[{ }^{18} \mathrm{~F}\right] \mathrm{VC701} \\
\text { SUVr in the cortex, } \\
\text { cerebellum, striatum, } \\
\text { hippocampus, } \\
\text { cervical enlargement } \\
\text { and thoracic and } \\
\text { lumbar spinal cord }\end{array}$ & $\begin{array}{l}\text { - PET data confirmed by } \\
\text { ex vivo biodistribution } \\
\text { of }\left[{ }^{18} \mathrm{~F}\right] \mathrm{VC} 701 \\
\text { - Iba1 IHC confirmed the } \\
\text { presence of } \\
\text { microglia/infiltrated } \\
\text { macrophages in the } \\
\text { same brain ROIs as } \\
\text { PET } \\
\text { - EAE lesion visible on } \\
\text { MRI but highly } \\
\text { variable in volume }\end{array}$ & [189] \\
\hline $\begin{array}{l}{\left[{ }^{11} \mathrm{C}\right] \mathrm{PBR} 28} \\
{\left[{ }^{18} \mathrm{~F}\right] \mathrm{FOL}(\mathrm{FR}-\beta)} \\
{[201]}\end{array}$ & $\begin{array}{l}\text { Investigate FR- } \beta \\
\text { expression and } \\
\text { evaluate its } \\
\text { potential as an } \\
\text { in vivo imaging } \\
\text { target in } \\
\text { comparison of } \\
\text { TSPO }\end{array}$ & $\begin{array}{l}\text { Intrastriatal injection of } \\
\text { heat-killed BCG followed } \\
\text { by intradermal injection of } \\
\text { Mycobacterium } \\
\text { tuberculosis- } \\
\text { H37Ra in male Lewis rats (3-4 } \\
\text { months old, } 235 \pm 9 \mathrm{~g} \text { ) }\end{array}$ & $\begin{array}{l}14 \text { and } 90 \text { days after } \\
\text { EAE induction }\end{array}$ & $\begin{array}{l}\text { - Increase in } \\
{\left[{ }^{11} \mathrm{C}\right] \text { PBR28 SUVr } 14} \\
\text { and 90 days after } \\
\text { EAE induction } \\
\text { - Increase in }\left[{ }^{18} \mathrm{~F}\right] \mathrm{FOL} \\
\text { SUVr, similar to } \\
{\left[{ }^{11} \mathrm{C}\right] \mathrm{PBR} 28 \mathrm{SUVr} \text {, at }} \\
14 \text { days } \\
\cdot\left[{ }^{18} \mathrm{~F}\right] \mathrm{FOL} \text { SUVr higher } \\
\text { than }\left[{ }^{11} \text { C]PBR28 }\right. \\
\text { SUVr at } 90 \text { days }\end{array}$ & $\begin{array}{l}\text { - ARG for }\left[{ }^{11} \mathrm{C}\right] \mathrm{PBR} 28 \\
\text { and }\left[{ }^{18} \mathrm{~F}\right] \mathrm{FOL} \\
\text { confirmed the PET data } \\
\text { - IHC confirmed the } \\
\text { presence of FR- } \beta \text {, } \\
\text { CD } 68, \text { MRC1 and } \\
\text { iNOS staining in the } \\
\text { same ROIs as PET, } \\
\text { especially at } 90 \text { days }\end{array}$ & {$[202]$} \\
\hline
\end{tabular}


Table 7 (continued)

\begin{tabular}{|c|c|c|c|c|c|c|}
\hline PET tracer $*$ & Rational & MS model and species & Imaging time points & Main imaging findings & Additional readouts & Ref. \\
\hline & $\begin{array}{l}\text { Feasibility study of } \\
\text { using TSPO-PET } \\
\text { to detect NI in } \\
\text { EAE and } \\
\text { determine which } \\
\text { cell types express } \\
\text { TSPO }\end{array}$ & $\begin{array}{l}\text { CPZ-induced EAE and/or } \\
\text { MOG }_{35-55} \text { immunization in } \\
\text { C57BL/6 mice and } \\
\text { hGFAP/EGFP (astrocyte), } \\
\text { CX3CR } 1^{+} / \text {eGFP/CCR2 } 2^{+}- \\
\text {RFP (monocyte-derived } \\
\text { macrophages) and } \\
\text { eGFP-expressing microglial } \\
\text { transgenic mice }\end{array}$ & $\begin{array}{l}5 \text { weeks after EAE } \\
\text { induction }\end{array}$ & 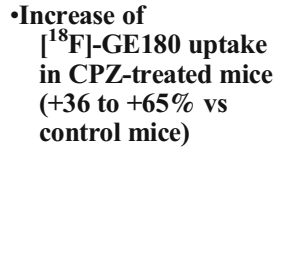 & $\begin{array}{l}\text { - IHC analysis revealed } \\
\text { that TSPO mostly } \\
\text { colocalize with } \\
\text { microglia following } \\
\text { CPZ } \\
\text { - The combination CPZ } \\
\text { and/or MOG } \mathrm{MOG}_{35-55} \\
\text { induces the recruitment } \\
\text { of TSPO+ monocytes }\end{array}$ & \\
\hline$\left[{ }^{18} \mathrm{~F}\right] \mathrm{GE}-180$ & $\begin{array}{l}\text { Test effect of } \\
\text { anti-VLA-4 } \\
\text { treatment in EAE }\end{array}$ & $\begin{array}{l}\text { Intrastriatal injection of } \\
\text { heat-killed BCG followed } \\
\text { by intradermal injection of } \\
\text { Mycobacterium } \\
\text { tuberculosis in male Lewis } \\
\text { rats }\end{array}$ & $\begin{array}{l}30,44,65,86 \text { and } \\
142 \text { after EAE } \\
\text { induction }\end{array}$ & $\begin{array}{l}\text { - Declining trend }(p= \\
0.067) \text { in } \\
\left.{ }^{18} \mathrm{~F}\right] \mathrm{GE}-180 \text {-binding } \\
\text { after } 2 \text { weeks of } \\
\text { anti-VLA-4 } \\
\text { mAb-treatment vs } \\
\text { controls } \\
\text { - After 31-days of } \\
\text { anti-VLA-4 mAb } \\
\text { treatment, cessation } \\
\text { of treatment } \\
\text { increased } \\
\text { [ }{ }^{18} \text { F]GE-180 binding } \\
\text { vs control group } \\
\text { - No difference between } \\
\text { groups in TSPO } \\
\text { binding by day } 142\end{array}$ & $\begin{array}{l}\text { IHC confirmed the } \\
\text { presence of Iba } 1^{+} \text {cells } \\
\text { in the lesion }\end{array}$ & {$[191]$} \\
\hline$\left[{ }^{18} \mathrm{~F}\right] \mathrm{DPA}-714$ & $\begin{array}{l}\text { Investigate the } \\
\text { temporal profile } \\
\text { of NI in relation } \\
\text { to MRI in EAE }\end{array}$ & $\begin{array}{l}\text { CPZ-induced EAE in female } \\
\text { C57B16 mice ( } 8 \text { weeks old, } \\
19.8 \pm 1.5 \mathrm{~g})\end{array}$ & $\begin{array}{l}4 \text { and } 5-6 \text { weeks after } \\
\text { EAE induction }\end{array}$ & $\begin{array}{l}\text { - }{ }^{18} \text { F]DPA- } 714 \\
\text { increased in EAE } \\
\text { mice at } 4 \text { weeks and } \\
\text { declined at } 6 \text { weeks in } \\
\text { the CC, hippocampus } \\
\text { and thalamus } \\
\text { - Increased T2 values in } \\
\text { the CC of CPZ } \\
\text { compared to control at } \\
3 \text { and } 5 \text { weeks } \\
\text { - Partial recovery of T2 } \\
\text { values between weeks } \\
3 \text { and } 5\end{array}$ & $\begin{array}{l}\text { - Ex vivo }\left[{ }^{18} \mathrm{~F}\right] \mathrm{DPA}-714 \\
\text { ARG confirmed the } \\
\text { PET data } \\
\text { - IHC: during } \\
\text { demyelination (week } \\
\text { 3), TSPO }{ }^{+} \text {cells are } \\
\text { microglia; during } \\
\text { remyelination, TSPO } \\
\text { cells are astrocytes } \\
\text { - IHC confirmed } \\
\text { remyelination at week } 6\end{array}$ & [193] \\
\hline$\left[{ }^{18} \mathrm{~F}\right] \mathrm{GE}-180$ & $\begin{array}{l}\text { Test MS treatment } \\
\text { laquinimod in } \\
\text { EAE model }\end{array}$ & $\begin{array}{l}\text { CPZ-induced EAE } \pm \\
\text { MOG }_{35-55} \text { immunization in } \\
\text { female C57B16 mice ( } 8 \\
\text { weeks old) }\end{array}$ & $\begin{array}{l}5 \text { weeks after EAE } \\
\text { induction }\end{array}$ & $\begin{array}{l}\text { - Laquinimod treatment } \\
\text { returned } \\
\text { EAE-induced } \\
\text { increased } \\
{ }^{18} \text { F]GE-180 uptake } \\
\text { to control values }\end{array}$ & $\begin{array}{l}\text { IHC measurements } \\
\text { confirmed reduced NI } \\
\text { and decrease of ND } \\
\text { markers }\end{array}$ & [192] \\
\hline$\left[{ }^{18} \mathrm{~F}\right] \mathrm{DPA}-714$ & $\begin{array}{l}\text { Feasibility study of } \\
\text { using TSPO-PET } \\
\text { and SPIO-MRI to } \\
\text { detect NI in EAE } \\
\text { and determine } \\
\text { which cell types } \\
\text { express TSPO }\end{array}$ & $\begin{array}{l}\text { Immunization with PLP } \mathrm{P}_{139-151} \\
\text { of female SJL/J mice (6 } \\
\text { weeks old) }\end{array}$ & $\begin{array}{l}11 \text { to } 14 \text { days } \\
\text { post-- } \\
\text { immunization }\end{array}$ & $\begin{array}{l}\cdot\left[{ }^{18} \text { F]DPA-714 SUVR }\right. \\
\text { and SPIO-volume } \\
\text { values were } \\
\text { significantly } \\
\text { increased in EAE } \\
\text { compared with the } \\
\text { controls in the } \\
\text { hippocampus, } \\
\text { thalamus, cerebellum } \\
\text { and brainstem } \\
\text { - Increased SPIO-Vol } \\
\text { only in the } \\
\text { caudate/putamen }\end{array}$ & $\begin{array}{l}\text { TSPO/Iba1 and } \\
\text { F4/80/Prussian blue } \\
\text { IHC staining suggests } \\
\text { that microglia and } \\
\text { macrophages are the } \\
\text { source of } \\
\left.{ }^{18} \mathrm{~F}\right] \mathrm{DPA}-714 \text { and } \\
\text { SPIO signal }\end{array}$ & [194] \\
\hline
\end{tabular}

*TSPO-PET tracers and associated results are in bold.

Abbreviations: $\left[{ }^{18} \mathrm{~F}\right] F D G$, fluorodeoxyglucose; $\left[{ }^{18} \mathrm{~F}\right] F O L$, $\left[{ }^{18} \mathrm{~F}\right]$ fluoride-labelled 1,4,7-triazacyclononane-1,4,7-triacetic acid conjugated folate; ${ }^{18}$ F]FSPG, (4S)-4-(3-18F-fluoropropyl)-L-glutamate; $A R G$, autoradiography; $B C G$, Bacillus Calmette-Guérin; $C C$, corpus callosum; $C P Z$, cuprizone; $E A E$, experimental autoimmune encephalomyelitis; $F R$ - $\beta$, folate receptor- $\beta ; I H C$, immunohistochemistry; $i N O S$, inducible nitric oxide synthase; $M B P$, myelin basic protein; $M e D A S, \mathrm{~N}$-methyl-4,4'-diaminostilbene; $M R C 1$, mannose receptor C-type 1; $N D$, neurodegeneration; $N I$, neuroinflammation; $S D$, Sprague Dawley; SPIO, superparamagnetic iron oxide particles; $S U V$, standard uptake value; $S U V r$, standard uptake value ratio; VLA-4, very late antigen-4 integrin; $W M$, white matter; $x c^{-}$: cystine-glutamate antiporter system 
neuroinflammation at the cessation of the treatment at 31 days, suggesting a dampening effect of the treatment on the pathophysiological processes. Similarly, Nedelcu et al. [192] investigated the effect of laquinimod in a mouse model of MS also using $\left[{ }^{18} \mathrm{~F}\right] \mathrm{GE}-180$. These authors demonstrated that laquinimod was able to reverse neuroinflammation to baseline levels confirming the potential of this treatment in MS as previously described [196, 197].

Some studies used a multitracer approach to investigate different parameters simultaneously in MS models. In a model of demyelination in rats, de Paula Faria et al. [198] used $\left[{ }^{11} \mathrm{C}\right]-$ R-PK11195 for TSPO expression, $\left[{ }^{11} \mathrm{C}\right] \mathrm{MeDAS}$ for myelin level and $\left[{ }^{18} \mathrm{~F}\right] \mathrm{FDG}$ for metabolism. While they showed no change in $\left[{ }^{18} \mathrm{~F}\right] \mathrm{FDG}$ uptake, they observed a significant increase $(+37$ to $+84 \%)$ in $\left[{ }^{11} \mathrm{C}\right]-\mathrm{R}-\mathrm{PK} 11195$ uptake in the lesion where myelin binding of $\left[{ }^{11} \mathrm{C}\right] \mathrm{MeDAS}$ was significantly decreased within a week. Similarly, Martin et al. [199] also found no change in $\left[{ }^{18} \mathrm{~F}\right] \mathrm{FDG}$ uptake in an EAE model in rats, while TSPO $\left(\left[{ }^{11} \mathrm{C}\right]-\mathrm{R}-\mathrm{PK} 11195\right)$ was significantly increased in the cerebellum and spinal cord, and cystine-glutamate antiporter system (system xc) $\left(\left[{ }^{18} \mathrm{~F}\right] \mathrm{FSPG}\right)$ was increased in the spinal cord 14 days post-EAE induction. As for the study in stroke [97], this raises the prospect of system $\mathrm{xc}^{-}$being involved in neuroinflammatory processes in MS and being a potential therapeutic target. Finally, and using $\left[{ }^{18} \mathrm{~F}\right] \mathrm{FOL}$ to target folate receptor- $\beta$ (FR- $\beta$ ) that is expressed on activated macrophages, Elo et al. investigated the use of FR- $\beta$ as a potential biomarker for neuroinflammation imaging in MS in comparison with $\left[{ }^{11} \mathrm{C}\right]$ PBR28 PET. Fourteen days postEAE induction, both $\left[{ }^{11} \mathrm{C}\right]$ PBR28 and $\left[{ }^{18} \mathrm{~F}\right] \mathrm{FOL}$ were similarly increased; however, at 90 days post-EAE induction, $\left[{ }^{18} \mathrm{~F}\right] \mathrm{FOL}$ uptake was higher than $\left[{ }^{11} \mathrm{C}\right]$ PBR28 uptake. Immunohistochemistry revealed that FR- $\beta$ was expressed by both microglia and macrophages in EAE lesion; however, the different uptake of both tracers at 90 days suggests that $\left[{ }^{18} \mathrm{~F}\right] \mathrm{FOL} / \mathrm{FR}-\beta$ imaging may be complementary of TSPO imaging in MS.

Overall, in preclinical models of MS, TSPO expression is robustly and consistently detected as it is the case in MS patients. In this context, TSPO imaging has a great potential as a readout for therapeutic response (Table 7).

\section{General conclusion}

Taken altogether, TSPO-PET imaging is highly valuable in assessing the time course, anatomical brain localization of neuroinflammation and response to treatment in a range of disease models from acute, subacute to chronic conditions. We observed that the TSPO-PET ligands that have been developed over the last 15 years to overcome the shortcomings of $\left[{ }^{11} \mathrm{C}\right]-\mathrm{R}-\mathrm{PK} 11195$ have been applied in a large variety of preclinical studies. To the best of our knowledge, the differential affinity of these ligands for the human TSPO polymorphisms has still not been an issue in preclinical research nor in larger animals. Recently, newer ligands, which are not sensitive to these polymorphisms, are integrating the field. Future studies will define if these ligands present an overall gain in preclinical research over $\left[{ }^{11} \mathrm{C}\right]-\mathrm{R}-\mathrm{PK} 11195$ in terms of signal-to-noise ratio. Clinical studies will then have to determine if this gain is translated into clinical imaging and if they are truly insensitive to the TSPO polymorphism in human.

Overall, we can conclude that TSPO-PET imaging is a powerful tool to evaluate the neuroinflammatory response in models with strong and localized effects, such as intracerebral administered toxic lesion models (LPS, QA, 6-OHDA) and stroke models. The main advantage of these models is the reproducibility and predictiveness of the size, localization and the time window of the neuroinflammatory response as well as the known cell origin of the TSPO expression. These parameters reduce considerably the inter-animal variability and simplify the experimental design. However, the major drawback of these models of acute neuroinflammation is the limited translational generalizability for neurological disorders with a systemic or chronic pathogenesis. This limitation highlights a strength of acute LPS administration, which can be given systematically, to model sickness behaviour and peripheral increase of inflammatory cytokines on the central neuroinflammatory response. However, dramatic species differences in LPS sensitivity are a key for translational consideration. On the other hand, viral vector-induced models or transgenic animal models of neurodegenerative diseases have the merit to better reflect the clinical pathology because they are slowly progressive, even though neuronal loss is often moderated within the time window of the experimental design. However, they also generate higher intra-animal variability and are more complex to handle in their experimental design. Additionally, the neuroinflammatory response in these models is often more modest and less well characterized but actually reproduces fairly well the amplitude and characteristics of the neuroinflammatory response observed in a clinical scenario. In animal models with a low and localized neuroimmune response, the use of ex vivo or in vitro autoradiography compensates for the limited resolution and sensitivity of in vivo PET imaging. A more general limitation is the use of SUV as a pseudo-quantitative measurement to overcome the complexities of blood sampling in small animal models. However, SUV is rarely compared with gold standard measurements of $V_{\mathrm{T}}$ and/or verify the free blood fraction of the ligand. When this measure is not homogeneous between experimental groups, an important bias may be introduced when using pseudo-quantitative parameters. This supports the development and use of animal models in larger species, such as non-human primates and minipigs, to circumvent some of the difficulties encountered when using rodents (small brain and limited possibilities of arterial blood 
sampling). A summary of the strengths and weaknesses of preclinical models described in this review is provided in Table 8.

Table 8 Strengths and weaknesses of preclinical models regarding TSPO-PET imaging

\begin{tabular}{|c|c|c|c|}
\hline Model & Pros & Cons & \\
\hline LPS & $\begin{array}{l}\text { - Intracerebral } \\
\text { administration } \\
\text { provides a robust } \\
\text { neuroinflammatory } \\
\text { response. } \\
\text { - Useful to model the } \\
\text { impact of systemic } \\
\text { inflammation on } \\
\text { neurodegenerative } \\
\text { and } \\
\text { neuroinflammatory } \\
\text { events }\end{array}$ & $\begin{array}{l}\text { - Important species } \\
\text { differences in } \\
\text { neuroinflammat- } \\
\text { ory response } \\
\text { after peripheral } \\
\text { LPS challenge } \\
\text { - Differences in } \\
\text { neuroinflammat- } \\
\text { ory responses } \\
\text { between batches } \\
\text { of LPS }\end{array}$ & \multirow{5}{*}{$\begin{array}{l}\text { - For most } \\
\text { models: small } \\
\text { brain size of } \\
\text { rodents, } \\
\text { particularly } \\
\text { mice, relative } \\
\text { to the } \\
\text { resolution of } \\
\text { preclinical } \\
\text { PET scanners. } \\
\text { - Need to } \\
\text { implement } \\
\text { more clinically } \\
\text { relevant } \\
\text { models in } \\
\text { larger species }\end{array}$} \\
\hline Stroke & $\begin{array}{l}\text { Robust, focal and } \\
\text { well-defined time } \\
\text { course of the } \\
\text { neuroinflammatory } \\
\text { response }\end{array}$ & $\begin{array}{l}\text { Complexity and/or } \\
\text { invasiveness of } \\
\text { surgery } \\
\text { (depending on } \\
\text { model) }\end{array}$ & \\
\hline & \multicolumn{2}{|c|}{$\begin{array}{l}\text { Moderate to good translational value } \\
\text { depending on the stroke model }\end{array}$} & \\
\hline $\mathrm{AD}$ & $\begin{array}{l}\text { Amplitudes of } \\
\text { increases in TSPO } \\
\text { expression are } \\
\text { similar in amplitude } \\
\text { to what is observed } \\
\text { in clinic }\end{array}$ & $\begin{array}{l}\text { Transgenic models } \\
\text { are only } \\
\text { modelling the } \\
\text { familial form of } \\
\text { AD }\end{array}$ & \\
\hline PD & $\begin{array}{l}\text { Within the time } \\
\text { window of the } \\
\text { experimental } \\
\text { design, } \\
\text { neurodegeneration } \\
\text { in viral } \\
\text { vector-induced } \\
\text { models is generally } \\
\text { mild, alongside a } \\
\text { modest and yet } \\
\text { poorly } \\
\text { characterized } \\
\text { neuroinflammatory } \\
\text { response }\end{array}$ & $\begin{array}{l}\text { Acute } \\
\text { neurodegenera- } \\
\text { tive models } \\
\text { present transient } \\
\text { neuroinflammat- } \\
\text { ory response } \\
\text { which is not } \\
\text { representative for } \\
\text { a chronic aspect } \\
\text { of clinical profile }\end{array}$ & \\
\hline HD & $\begin{array}{l}\text { Robust, focal, strong, } \\
\text { rapid and } \\
\text { well-defined time } \\
\text { course of } \\
\text { neuroinflammatory } \\
\text { response (QA) }\end{array}$ & $\begin{array}{l}\text { Poor to moderate } \\
\text { translational } \\
\text { value; } \\
\text { invasiveness of } \\
\text { surgery (QA) }\end{array}$ & \\
\hline MS & $\begin{array}{l}\text { Easy to induce, rapid } \\
\text { neuroinflammatory } \\
\text { response }\end{array}$ & & \\
\hline
\end{tabular}

Altogether, these TSPO-PET imaging studies demonstrated the implication and possible modulation of neuroinflammation by various systems in preclinical models and offered new insights into disease mechanisms and associated potential new therapeutic avenues. Additionally, they showed that these phenomena can be monitored in vivo longitudinally using preclinical PET alone (using one or several radiotracers) or in combination with other non-invasive imaging techniques. Importantly, these studies confirmed further the true potential of preclinical PET imaging and the still undeniable value of TSPO-PET to image neuroinflammation even though TSPO might not be seen as the ideal direct biomarker for neuroinflammation.

Interestingly, all these preclinical studies highlight the strengths and values of preclinical models in which it is possible to investigate the detailed cellular expression of TSPO (in microglia, macrophages, astrocytes and endothelial cells) as well as the meaning of such overexpression in the context of the cellular phenotype (pro- vs anti-inflammatory) and in relation with the immune response observed in these disease models, something that can be done only at the latest stage of disease in human samples.

There are many arguments that can be raised regarding the imperfection of TSPO as a biomarker of neuroinflammation since TSPO is not directly involved in the inflammatory responses as are a wide range of molecule such as cytokines, chemokines, P2X7 receptors, inflammasomes, etc. Nevertheless, until other biomarkers and associated radiotracers can fulfil the gap of TSPO shortfall, TSPO remains a tool of choice to investigate and understand neuroinflammation and response to anti-inflammatory treatment in animal models, and it still has an incredible value as a translational target for neuroinflammation imaging in clinic.

\section{Declarations}

Conflicts of interest $\mathrm{HB}$ has received funding from GSK. GSK was not involved in any way in the redaction of this review.

Open Access This article is licensed under a Creative Commons Attribution 4.0 International License, which permits use, sharing, adaptation, distribution and reproduction in any medium or format, as long as you give appropriate credit to the original author(s) and the source, provide a link to the Creative Commons licence, and indicate if changes were made. The images or other third party material in this article are included in the article's Creative Commons licence, unless indicated otherwise in a credit line to the material. If material is not included in the article's Creative Commons licence and your intended use is not permitted by statutory regulation or exceeds the permitted use, you will need to obtain permission directly from the copyright holder. To view a copy of this licence, visit http://creativecommons.org/licenses/by/4.0/. 


\section{References}

1. Benavides J, Malgouris C, Imbault F, Begassat F, Uzan A, Renault $\mathrm{C}$, et al. "Peripheral type" benzodiazepine binding sites in rat adrenals: binding studies with [3H]PK 11195 and autoradiographic localization. Arch Int Pharmacodyn Ther. 1983;266: $38-49$.

2. Le Fur G, Vaucher N, Perrier ML, Flamier A, Benavides J, Renault $\mathrm{C}$, et al. Differentiation between two ligands for peripheral benzodiazepine binding sites, [3H]RO5-4864 and [3H]PK 11195, by thermodynamic studies. Life Sci. 1983;33:449-57.

3. Benavides J, Guilloux F, Rufat P, Uzan A, Renault C, Dubroeucq $\mathrm{MC}$, et al. In vivo labelling in several rat tissues of 'peripheral type' benzodiazepine binding sites. Eur J Pharmacol. 1984;99:1-7.

4. Benavides J, Fage D, Carter C, Scatton B. Peripheral type benzodiazepine binding sites are a sensitive indirect index of neuronal damage. Brain Res. 1987;421(1-2):167-72. https://doi.org/10. 1016/0006-8993(87)91287-x.

5. Dubois A, Benavides J, Peny B, Duverger D, Fage D, Gotti B, et al. Imaging of primary and remote ischaemic and excitotoxic brain lesions. An autoradiographic study of peripheral type benzodiazepine binding sites in the rat and cat. Brain Res. 1988;445(1):77-90. https://doi.org/10.1016/0006-8993(88) 91076-1.

6. Black KL, Ikezaki K, Toga AW. Imaging of brain tumors using peripheral benzodiazepine receptor ligands. J Neurosurg. 1989;71: 113-8.

7. Benavides J, Dubois A, Gotti B, Bourdiol F, Scatton B. Cellular distribution of omega 3 (peripheral type benzodiazepine) binding sites in the normal and ischaemic rat brain: an autoradiographic study with the photoaffinity ligand [3H]PK 14105 . Neurosci Lett. 1990;114(1):32-8. https://doi.org/10.1016/0304-3940(90)904248.

8. Benavides J, Capdeville C, Dauphin F, Dubois A, Duverger D, Fage D, et al. The quantification of brain lesions with an $\omega_{3}$ site ligand: a critical analysis of animal models of cerebral ischaemia and neurodegeneration. Brain Res. 1990;522:275-89.

9. Pappata S, Cornu P, Samson Y, Prenant C, Benavides J, Scatton B, et al. PET study of carbon-11-PK 11195 binding to peripheral type benzodiazepine sites in glioblastoma: a case report. J Nucl Med. 1991;32(8):1608-10.

10. Bergstrom M, Mosskin M, Ericson K, Ehrin E, Thorell JO, von Holst $\mathrm{H}$, et al. Peripheral benzodiazepine binding sites in human gliomas evaluated with positron emission tomography. Acta Radiol Suppl. 1986;369:409-11.

11. Stephenson DT, Schober DA, Smalstig EB, Mincy RE, Gehlert DR, Clemens JA. Peripheral benzodiazepine receptors are colocalized with activated microglia following transient global forebrain ischemia in the rat. J Neurosci. 1995;15(7 Pt 2):526374.

12. Banati RB, Myers R, Kreutzberg GW. PK ('peripheral benzodiazepine')-binding sites in the CNS indicate early and discrete brain lesions: microautoradiographic detection of $[3 \mathrm{H}] \mathrm{PK} 11195$ binding to activated microglia. J Neurocytol. 1997;26:77-82.

13. Vowinckel E, Reutens D, Becher B, Verge G, Evans A, Owens T, et al. PK11195 binding to the peripheral benzodiazepine receptor as a marker of microglia activation in multiple sclerosis and experimental autoimmune encephalomyelitis. J Neurosci Res. 1997;50:345-53.

14. Banati RB, Goerres GW, Myers R, Gunn RN, Turkheimer FE, Kreutzberg GW, et al. [11C](R)-PK11195 positron emission tomography imaging of activated microglia in vivo in Rasmussen's encephalitis. Neurology. 1999;53(9):2199-203. https://doi.org/ 10.1212/wnl.53.9.2199.
15. Brown GC. The endotoxin hypothesis of neurodegeneration. J Neuroinflammation. 2019;16(1):180. https://doi.org/10.1186/ s12974-019-1564-7.

16. Qin L, Wu X, Block ML, Liu Y, Breese GR, Hong JS, et al. Systemic LPS causes chronic neuroinflammation and progressive neurodegeneration. Glia. 2007;55(5):453-62. https://doi.org/10. 1002/glia.20467.

17. Vargas-Caraveo A, Sayd A, Maus SR, Caso JR, Madrigal JLM, Garcia-Bueno B, et al. Lipopolysaccharide enters the rat brain by a lipoprotein-mediated transport mechanism in physiological conditions. Sci Rep. 2017;7(1):13113. https://doi.org/10.1038/s41598017-13302-6.

18. Furube E, Kawai S, Inagaki H, Takagi S, Miyata S. Brain regiondependent heterogeneity and dose-dependent difference in transient microglia population increase during lipopolysaccharideinduced inflammation. Sci Rep. 2018;8(1):2203. https://doi.org/ 10.1038/s41598-018-20643-3.

19. Hoogland IC, Houbolt C, van Westerloo DJ, van Gool WA, van de Beek D. Systemic inflammation and microglial activation: systematic review of animal experiments. J Neuroinflammation. 2015;12(1):114. https://doi.org/10.1186/s12974-015-0332-6.

20. Lopes PC. LPS and neuroinflammation: a matter of timing. Inflammopharmacology. 2016;24(5):291-3. https://doi.org/10. 1007/s10787-016-0283-2.

21. Ota M, Ogura J, Ogawa S, Kato K, Matsuda H, Kunugi H. A single intraperitoneal injection of endotoxin changes glial cells in rats as revealed by positron emission tomography using [(11)C]PK11195. Nucl Med Mol Imaging. 2018;52(3):224-8. https://doi.org/10.1007/s13139-017-0510-9.

22. Schildt A, Walker MD, Dinelle K, Miao Q, Schulzer M, O'Kusky $\mathrm{J}$, et al. Single inflammatory trigger leads to neuroinflammation in LRRK2 rodent model without degeneration of dopaminergic neurons. J Parkinsons Dis. 2019;9(1):121-39. https://doi.org/10. 3233/JPD-181446

23. Schedlowski M, Engler H, Grigoleit J-S. Endotoxin-induced experimental systemic inflammation in humans: a model to disentangle immune-to-brain communication. Brain Behav Immun. 2014;35:1-8. https://doi.org/10.1016/j.bbi.2013.09.015.

24. Hannestad J, Gallezot JD, Schafbauer T, Lim K, Kloczynski T, Morris ED, et al. Endotoxin-induced systemic inflammation activates microglia: [(1)(1)C]PBR28 positron emission tomography in nonhuman primates. Neuroimage. 2012;63(1):232-9. https:// doi.org/10.1016/j.neuroimage.2012.06.055

25. Sandiego CM, Gallezot JD, Pittman B, Nabulsi N, Lim K, Lin SF, et al. Imaging robust microglial activation after lipopolysaccharide administration in humans with PET. Proc Natl Acad Sci U S A. 2015;112(40):12468-73. https://doi.org/10.1073/pnas. 1511003112 .

26. Hillmer AT, Holden D, Fowles K, Nabulsi N, West BL, Carson RE, et al. Microglial depletion and activation: a [11C]PBR28 PET study in nonhuman primates. EJNMMI Res. 2017;7(1):59. https:// doi.org/10.1186/s13550-017-0305-0.

27. Murtaj V, Belloli S, Di Grigoli G, Pannese M, Ballarini E, Rodriguez-Menendez V, et al. Age and sex influence the neuroinflammatory response to a peripheral acute LPS challenge. Front Aging Neurosci. 2019;11:299. https://doi.org/10.3389/fnagi. 2019.00299.

28. Kim WG, Mohney RP, Wilson B, Jeohn GH, Liu B, Hong JS. Regional difference in susceptibility to lipopolysaccharideinduced neurotoxicity in the rat brain: role of microglia. $\mathrm{J}$ Neurosci. 2000;20(16):6309-16.

29. Ito F, Toyama H, Kudo G, Suzuki H, Hatano K, Ichise M, et al. Two activated stages of microglia and PET imaging of peripheral benzodiazepine receptors with [(11)C]PK11195 in rats. Ann Nucl Med. 2010;24(3):163-9. https://doi.org/10.1007/s12149-0090339-0. 
30. Tournier BB, Tsartsalis S, Ceyzeriat K, Medina Z, Fraser BH, Gregoire MC, et al. Fluorescence-activated cell sorting to reveal the cell origin of radioligand binding. J Cereb Blood Flow Metab. $2020 ; 40(6): 1242-55$. https://doi.org/10.1177/ $0271678 X 19860408$

31. Vignal N, Boulay AC, San C, Cohen-Salmon M, Rizzo-Padoin N, Sarda-Mantel L, et al. Astroglial connexin 43 deficiency protects against LPS-induced neuroinflammation: a TSPO brain microPET study with [(18)F]FEPPA. Cells. 2020;9(2). https://doi.org/10. 3390/cells9020389.

32. Liddelow SA, Guttenplan KA, Clarke LE, Bennett FC, Bohlen CJ, Schirmer L, et al. Neurotoxic reactive astrocytes are induced by activated microglia. Nature. 2017;541(7638):481-7. https://doi. org/10.1038/nature21029.

33. Pannell M, Economopoulos V, Wilson TC, Kersemans V, Isenegger PG, Larkin JR, et al. Imaging of translocator protein upregulation is selective for pro-inflammatory polarized astrocytes and microglia. Glia. 2020;68(2):280-97. https://doi.org/10. 1002/glia.23716.

34. Ory D, Planas A, Dresselaers T, Gsell W, Postnov A, Celen S, et al. PET imaging of TSPO in a rat model of local neuroinflammation induced by intracerebral injection of lipopolysaccharide. Nucl Med Biol. 2015;42(10):753-61. https://doi.org/10.1016/j. nucmedbio.2015.06.010.

35. Pottier G, Gomez-Vallejo V, Padro D, Boisgard R, Dolle F, Llop $\mathrm{J}$, et al. PET imaging of cannabinoid type 2 receptors with [(11)C]A-836339 did not evidence changes following neuroinflammation in rats. J Cereb Blood Flow Metab. 2017;37(3): 1163-78. https://doi.org/10.1177/0271678X16685105.

36. Owen DR, Narayan N, Wells L, Healy L, Smyth E, Rabiner EA, et al. Pro-inflammatory activation of primary microglia and macrophages increases $18 \mathrm{kDa}$ translocator protein expression in rodents but not humans. J Cereb Blood Flow Metab. 2017;37(8): 2679-90. https://doi.org/10.1177/0271678x17710182.

37. Kim K, Kim H, Bae SH, Lee SY, Kim YH, Na J, et al. [(18)F]CB251 PET/MR imaging probe targeting translocator protein (TSPO) independent of its polymorphism in a neuroinflammation model. Theranostics. 2020;10(20):9315-31. https://doi. org/10.7150/thno.46875

38. Moon BS, Kim BS, Park C, Jung JH, Lee YW, Lee H-Y, et al. [18F] Fluoromethyl-PBR28 as a potential radiotracer for TSPO: preclinical comparison with [11C] PBR28 in a rat model of neuroinflammation. Bioconjug Chem. 2014;25(2):442-50.

39. Venneti S, Lopresti BJ, Wang G, Slagel SL, Mason NS, Mathis CA, et al. A comparison of the high-affinity peripheral benzodiazepine receptor ligands DAA1106 and (R)-PK11195 in rat models of neuroinflammation: implications for PET imaging of microglial activation. J Neurochem. 2007;102(6):2118-31. https://doi.org/10.1111/j.1471-4159.2007.04690.x.

40. Sridharan S, Lepelletier FX, Trigg W, Banister S, Reekie T, Kassiou M, et al. Comparative evaluation of Three TSPO PET radiotracers in a LPS-induced model of mild neuroinflammation in rats. Molec imag Biol. 2017;19(1):77-89. https://doi.org/10. 1007/s11307-016-0984-3.

41. Berdyyeva T, Xia C, Taylor N, He Y, Chen G, Huang C, et al. PET imaging of the P2X7 ion channel with a novel tracer [(18)F]JNJ-64413739 in a rat model of neuroinflammation. Molec imag Biol. 2019;21(5):871-8. https://doi.org/10.1007/ s11307-018-01313-2.

42. Flores-Martinez YM, Fernandez-Parrilla MA, Ayala-Davila J, Reyes-Corona D, Blanco-Alvarez VM, Soto-Rojas LO, et al. Acute neuroinflammatory response in the substantia nigra pars compacta of rats after a local injection of lipopolysaccharide. J Immunol Res. 2018;2018:1838921. https://doi.org/10.1155/ 2018/1838921.
43. Choi DY, Liu M, Hunter RL, Cass WA, Pandya JD, Sullivan PG, et al. Striatal neuroinflammation promotes Parkinsonism in rats. PLoS One. 2009;4(5):e5482. https://doi.org/10.1371/journal. pone.0005482.

44. Ory D, Postnov A, Koole M, Celen S, de Laat B, Verbruggen A, et al. Quantification of TSPO overexpression in a rat model of local neuroinflammation induced by intracerebral injection of LPS by the use of [(18)F]DPA-714 PET. Eur J Nucl Med Mol Imaging. 2016;43(1):163-72. https://doi.org/10.1007/s00259015-3172-9.

45. Vignal N, Cisternino S, Rizzo-Padoin N, San C, Hontonnou F, Gele T, et al. [(18)F]FEPPA a TSPO radioligand: optimized radiosynthesis and evaluation as a PET radiotracer for brain inflammation in a peripheral LPS-Injected mouse model. Molecules (Basel, Switzerland). 2018;23(6). https://doi.org/10.3390/ molecules23061375.

46. Woodcock EA, Schain M, Cosgrove KP, Hillmer AT. Quantification of [(11)C]PBR28 data after systemic lipopolysaccharide challenge. EJNMMI Res. 2020;10(1):19. https://doi.org/ 10.1186/s13550-020-0605-7.

47. Zhang Z, Jyoti A, Balakrishnan B, Williams M, Singh S, Chugani $\mathrm{DC}$, et al. Trajectory of inflammatory and microglial activation markers in the postnatal rabbit brain following intrauterine endotoxin exposure. Neurobiol Dis. 2018;111:153-62. https://doi.org/ 10.1016/j.nbd.2017.12.013.

48. Hieu Tran V, Park H, Park J, Kwon YD, Kang S, Ho Jung J, et al. Synthesis and evaluation of novel potent TSPO PET ligands with 2-phenylpyrazolo[1,5-a]pyrimidin-3-yl acetamide. Bioorg Med Chem. 2019;27(18):4069-80. https://doi.org/10.1016/j.bmc. 2019.07.036.

49. Kwon YD, Kang S, Park H, Cheong IK, Chang KA, Lee SY, et al. Novel potential pyrazolopyrimidine based translocator protein ligands for the evaluation of neuroinflammation with PET. Eur $\mathbf{J}$ Med Chem. 2018;159:292-306. https://doi.org/10.1016/j.ejmech. 2018.09.069.

50. Moon BS, Jung JH, Park HS, Contino M, Denora N, Lee BC, et al. Preclinical comparison study between [(18)F]fluoromethylPBR28 and its deuterated analog in a rat model of neuroinflammation. Bioorg Med Chem Lett. 2018;28(17):2925-9. https://doi. org/10.1016/j.bmcl.2018.07.011.

51. Vieira IF, Ory D, Casteels C, Lima FRA, Van Laere K, Bormans $\mathrm{G}$, et al. Volume-of-interest-based supervised cluster analysis for pseudo-reference region selection in [(18)F]DPA-714 PET imaging of the rat brain. EJNMMI Res. 2018;8(1):112. https://doi.org/ 10.1186/s13550-018-0467-4.

52. Dickens AM, Vainio S, Marjamaki P, Johansson J, Lehtiniemi P, Rokka J, et al. Detection of microglial activation in an acute model of neuroinflammation using PET and radiotracers 11C-(R)PK11195 and 18F-GE-180. J Nucl Med. 2014;55(3):466-72. https://doi.org/10.2967/jnumed.113.125625.

53. Buttini M, Sauter A, Boddeke HW. Induction of interleukin-1 beta mRNA after focal cerebral ischaemia in the rat. Brain Res Mol Brain Res. 1994;23(1-2):126-34. https://doi.org/10.1016/0169328x(94)90218-6.

54. Grau AJ. Infection, inflammation, and cerebrovascular ischemia. Neurology. 1997;49(5 Suppl 4):S47-51. https://doi.org/10.1212/ wnl.49.5_suppl_4.s47.

55. Touzani O, Boutin H, Chuquet J, Rothwell N. Potential mechanisms of interleukin-1 involvement in cerebral ischaemia. J Neuroimmunol. 1999;100(1-2):203-15. https://doi.org/10.1016/ s0165-5728(99)00202-7.

56. Benavides J, Cornu P, Dennis T, Dubois A, Hauw JJ, MacKenzie ET, et al. Imaging of human brain lesions with an omega 3 site radioligand. Ann Neurol. 1988;24(6):708-12. https://doi.org/10. 1002/ana.410240603. 
57. Pappata S, Levasseur M, Gunn RN, Myers R, Crouzel C, Syrota A, et al. Thalamic microglial activation in ischemic stroke detected in vivo by PET and [11C]PK11195. Neurology. 2000;55:1052-4.

58. Gerhard A, Schwarz J, Myers R, Wise R, Banati RB. Evolution of microglial activation in patients after ischemic stroke: a $[11 \mathrm{C}](\mathrm{R})-$ PK11195 PET study. Neuroimage. 2005;24(2):591-5. https://doi. org/10.1016/j.neuroimage.2004.09.034.

59. Price CJ, Wang D, Menon DK, Guadagno JV, Cleij M, Fryer T, et al. Intrinsic activated microglia map to the peri-infarct zone in the subacute phase of ischemic stroke. Stroke. 2006;37(7):1749 53. https://doi.org/10.1161/01.STR.0000226980.95389.0b.

60. Boutin H, Pinborg LH. TSPO imaging in stroke: from animal models to human subjects. Clin Transl Imaging. 2015;3(6):42335. https://doi.org/10.1007/s40336-015-0146-7.

61. Petit-Taboue MC, Baron JC, Barre L, Travere JM, Speckel D, Camsonne R, et al. Brain kinetics and specific binding of [11C]PK 11195 to omega 3 sites in baboons: positron emission tomography study. Eur J Pharmacol. 1991;200(2-3):347-51. https://doi.org/10.1016/0014-2999(91)90594-g.

62. Sette G, Baron JC, Young AR, Miyazawa H, Tillet I, Barre L, et al. In vivo mapping of brain benzodiazepine receptor changes by positron emission tomography after focal ischemia in the anesthetized baboon. Stroke. 1993;24(12):2046-57; discussion 57-8. https://doi.org/10.1161/01.str.24.12.2046.

63. Imaizumi M, Kim HJ, Zoghbi SS, Briard E, Hong J, Musachio JL, et al. PET imaging with [(11)C]PBR28 can localize and quantify upregulated peripheral benzodiazepine receptors associated with cerebral ischemia in rat. Neurosci Lett. 2007;411:200-5.

64. Boutin H, Prenant C, Maroy R, Galea J, Greenhalgh AD, Smigova A, et al. $\left[{ }^{18}\right.$ F]DPA-714: direct comparison with $\left[{ }^{11} \mathrm{C}\right] \mathrm{PK} 11195$ in a model of cerebral ischemia in rats. PLoS One. 2013;8(2): e56441. https://doi.org/10.1371/journal.pone.0056441.

65. Martin A, Boisgard R, Theze B, Van Camp N, Kuhnast B, Damont A, et al. Evaluation of the PBR/TSPO radioligand [(18)F]DPA-714 in a rat model of focal cerebral ischemia. J Cereb Blood Flow Metab. 2010;30(1):230-41. https://doi.org/ 10.1038/jcbfm.2009.205.

66. Tiwari AK, Ji B, Yui J, Fujinaga M, Yamasaki T, Xie L, et al. [18F]FEBMP: positron emission tomography imaging of TSPO in a model of neuroinflammation in rats, and in vitro autoradiograms of the human brain. Theranostics. 2015;5(9):961-9. https://doi. org/10.7150/thno.12027.

67. Boutin H, Murray K, Pradillo J, Maroy R, Smigova A, Gerhard A, et al. 18F-GE-180: a novel TSPO radiotracer compared to 11C-RPK11195 in a preclinical model of stroke. Eur J Nucl Med Mol Imaging. 2015;42(3):503-11. https://doi.org/10.1007/s00259014-2939-8.

68. Buchert R, Dirks M, Schutze C, Wilke F, Mamach M, Wirries AK, et al. Reliable quantification of (18)F-GE-180 PET neuroinflammation studies using an individually scaled population-based input function or late tissue-to-blood ratio. Eur J Nucl Med Mol Imaging. 2020;47(12):2887-900. https://doi.org/10.1007/s00259020-04810-1.

69. de Groot M, Patel N, Manavaki R, Janiczek RL, Bergstrom M, Ostor A, et al. Quantifying disease activity in rheumatoid arthritis with the TSPO PET ligand (18)F-GE-180 and comparison with (18)F-FDG and DCE-MRI. EJNMMI Res. 2019;9(1):113. https:// doi.org/10.1186/s13550-019-0576-8.

70. Sridharan S, Raffel J, Nandoskar A, Record C, Brooks DJ, Owen $\mathrm{D}$, et al. Confirmation of specific binding of the $18-\mathrm{kDa}$ translocator protein (TSPO) radioligand [(18)F]GE-180: a blocking study using XBD173 in multiple sclerosis normal appearing white and grey matter. Molec imag Biol. 2019;21(5): 935-44. https://doi.org/10.1007/s11307-019-01323-8.

71. Unterrainer M, Fleischmann DF, Vettermann F, Ruf V, Kaiser L, Nelwan D, et al. TSPO PET, tumour grading and molecular genetics in histologically verified glioma: a correlative (18)FGE-180 PET study. Eur J Nucl Med Mol Imaging. 2020;47(6): 1368-80. https://doi.org/10.1007/s00259-019-04491-5.

72. Vettermann FJ, Unterrainer M, Ruf V, Fleischmann DF, Rupprecht R, Forbrig R, et al. Dual PET imaging of an H3K27M-mutant glioma with 18F-GE-180 and 18F-FET PET. Clin Nucl Med. 2020;45(12):992-3. https://doi.org/10.1097/ RLU.0000000000003331.

73. Volk S, Unterrainer M, Albert NL, Havla J, Gerdes LA, Schumacher M, et al. TSPO PET with $18 \mathrm{~F}-\mathrm{GE}-180$ to differentiate variants of multiple sclerosis: relapsing-remitting multiple sclerosis, tumefactive demyelination, and Balo's concentric sclerosis. Clin Nucl Med. 2020;45(10):e447-e8. https://doi.org/10. 1097/RLU.0000000000003220.

74. Fujinaga M, Luo R, Kumata K, Zhang Y, Hatori A, Yamasaki T, et al. Development of a (18)F-labeled radiotracer with improved brain kinetics for positron emission tomography imaging of translocator protein $(18 \mathrm{kDa})$ in ischemic brain and glioma. $\mathrm{J}$ Med Chem. 2017;60(9):4047-61. https://doi.org/10.1021/acs. jmedchem. 7b00374.

75. Fujinaga M, Kumata K, Zhang Y, Hatori A, Yamasaki T, Mori W, et al. Synthesis of two novel [(18)F]fluorobenzene-containing radiotracers via spirocyclic iodonium ylides and positron emission tomography imaging of translocator protein $(18 \mathrm{kDa})$ in ischemic brain. Org Biomol Chem. 2018;16(37):8325-35. https://doi.org/ 10.1039/c8ob01700j.

76. Pulagam KR, Colas L, Padro D, Plaza-Garcia S, Gomez-Vallejo $\mathrm{V}$, Higuchi M, et al. Evaluation of the novel TSPO radiotracer [(18)F] VUIIS1008 in a preclinical model of cerebral ischemia in rats. EJNMMI Res. 2017;7(1):93. https://doi.org/10.1186/ s13550-017-0343-7.

77. Tang D, Fujinaga M, Hatori A, Zhang Y, Yamasaki T, Xie L, et al. Evaluation of the novel TSPO radiotracer 2-(7-butyl-2-(4-(2[(18)F]fluoroethoxy)phenyl)-5-methylpyrazolo[1,5-a]pyrimidin3-yl)-N,N-diethylacetamide in a preclinical model of neuroinflammation. Eur J Med Chem. 2018;150:1-8. https://doi.org/10.1016/ j.ejmech.2018.02.076.

78. Wang L, Cheng R, Fujinaga M, Yang J, Zhang Y, Hatori A, et al. A facile radiolabeling of [(18)F]FDPA via spirocyclic iodonium ylides: preliminary PET imaging studies in preclinical models of neuroinflammation. J Med Chem. 2017;60(12):5222-7. https:// doi.org/10.1021/acs.jmedchem.7b00432.

79. Keller T, Krzyczmonik A, Forsback S, Picon FRL, Kirjavainen AK, Takkinen J, et al. Radiosynthesis and preclinical evaluation of [(18)F]F-DPA, a novel pyrazolo[1,5a]pyrimidine acetamide TSPO radioligand, in healthy Sprague Dawley rats. Molec imag Biol. 2017;19(5):736-45. https://doi.org/10.1007/s11307-0161040-z.

80. Chaney A, Cropper HC, Johnson EM, Lechtenberg KJ, Peterson TC, Stevens MY, et al. (11)C-DPA-713 versus (18)F-GE-180: a preclinical comparison of translocator protein $18 \mathrm{kDa}$ PET tracers to visualize acute and chronic neuroinflammation in a mouse model of ischemic stroke. J Nucl Med. 2019;60(1):122-8. https://doi. org/10.2967/jnumed.118.209155.

81. de Lange C, Solberg R, Holtedahl JE, Tulipan A, Barlinn J, Trigg $\mathrm{W}$, et al. Dynamic TSPO-PET for assessing early effects of cerebral hypoxia and resuscitation in new born pigs. Nucl Med Biol. 2018;66:49-57. https://doi.org/10.1016/j.nucmedbio.2018.08. 004.

82. Thomas C, Vercouillie J, Domene A, Tauber C, Kassiou M, Guilloteau D, et al. Detection of neuroinflammation in a rat model of subarachnoid hemorrhage using [18F]DPA-714 PET imaging. Mol Imaging. 2016;15. https://doi.org/10.1177/ 1536012116639189.

83. Toth M, Little P, Arnberg F, Haggkvist J, Mulder J, Halldin C, et al. Acute neuroinflammation in a clinically relevant focal cortical 
ischemic stroke model in rat: longitudinal positron emission tomography and immunofluorescent tracking. Brain Struct Funct. 2016;221(3):1279-90. https://doi.org/10.1007/s00429-014-0970-y.

84. Miyajima N, Ito M, Rokugawa T, Iimori H, Momosaki S, Omachi $\mathrm{S}$, et al. Detection of neuroinflammation before selective neuronal loss appearance after mild focal ischemia using [(18)F]DPA-714 imaging. EJNMMI Res. 2018;8(1):43. https://doi.org/10.1186/ s13550-018-0400-x.

85. Walter HL, Walberer M, Rueger MA, Backes H, Wiedermann D, Hoehn M, et al. In vivo analysis of neuroinflammation in the late chronic phase after experimental stroke. Neuroscience. 2015;292: 71-80. https://doi.org/10.1016/j.neuroscience.2015.02.024.

86. Al-Khishman NU, Qi Q, Roseborough AD, Levit A, Allman BL, Anazodo UC, et al. TSPO PET detects acute neuroinflammation but not diffuse chronically activated MHCII microglia in the rat. EJNMMI Res. 2020;10(1):113. https://doi.org/10.1186/s13550020-00699-x.

87. Backes H, Walberer M, Ladwig A, Rueger MA, Neumaier B, Endepols $\mathrm{H}$, et al. Glucose consumption of inflammatory cells masks metabolic deficits in the brain. Neuroimage. 2016;128: 54-62. https://doi.org/10.1016/j.neuroimage.2015.12.044.

88. Ichiya Y, Kuwabara Y, Sasaki M, Yoshida T, Akashi Y, Murayama S, et al. FDG-PET in infectious lesions: the detection and assessment of lesion activity. Ann Nucl Med. 1996;10(2): 185-91. https://doi.org/10.1007/BF03165391.

89. Oyen WJ, Mansi L. FDG-PET in infectious and inflammatory disease. Eur J Nucl Med Mol Imaging. 2003;30(11):1568-70. https://doi.org/10.1007/s00259-003-1359-y.

90. Lawal I, Sathekge M. F-18 FDG PET/CT imaging of cardiac and vascular inflammation and infection. Br Med Bull. 2016;120(1): 55-74. https://doi.org/10.1093/bmb/ldw035.

91. Henderson F, Hart PJ, Pradillo JM, Kassiou M, Christie L, Williams KJ, et al. Multi-modal imaging of long-term recovery post-stroke by positron emission tomography and matrix-assisted laser desorption/ionisation mass spectrometry. Rapid Commun Mass Spectrom. 2018;32(9):721-9. https://doi.org/10.1002/rcm. 8090.

92. Lepelletier FX, Vandesquille M, Asselin MC, Prenant C, Robinson AC, Mann DMA, et al. Evaluation of (18)F-IAM6067 as a sigma-1 receptor PET tracer for neurodegeneration in vivo in rodents and in human tissue. Theranostics. 2020;10(18):7938-55. https://doi.org/10.7150/thno.47585.

93. Hosoya T, Fukumoto D, Kakiuchi T, Nishiyama S, Yamamoto S, Ohba $\mathrm{H}$, et al. In vivo TSPO and cannabinoid receptor type 2 availability early in post-stroke neuroinflammation in rats: a positron emission tomography study. J Neuroinflammation. 2017;14(1):69. https://doi.org/10.1186/s12974-017-0851-4.

94. Zinnhardt B, Viel T, Wachsmuth L, Vrachimis A, Wagner S, Breyholz HJ, et al. Multimodal imaging reveals temporal and spatial microglia and matrix metalloproteinase activity after experimental stroke. J Cereb Blood Flow Metab. 2015;35(11):1711-21. https://doi.org/10.1038/jcbfm.2015.149.

95. Barca C, Foray C, Hermann S, Doring C, Schafers M, Jacobs AH, et al. Characterization of the inflammatory post-ischemic tissue by full volumetric analysis of a multimodal imaging dataset. Neuroimage. 2020;222:117217. https://doi.org/10.1016/j. neuroimage.2020.117217.

96. Martin A, Szczupak B, Gomez-Vallejo V, Domercq M, Cano A, Padro D, et al. In vivo PET imaging of the alpha4beta2 nicotinic acetylcholine receptor as a marker for brain inflammation after cerebral ischemia. J Neurosci. 2015;35(15):5998-6009. https:// doi.org/10.1523/JNEUROSCI.3670-14.2015.

97. Domercq M, Szczupak B, Gejo J, Gomez-Vallejo V, Padro D, Gona KB, et al. PET imaging with [(18)F]FSPG evidences the role of system $\mathrm{xc}(-)$ on brain inflammation following cerebral ischemia in rats. Theranostics. 2016;6(11):1753-67. https://doi. org/10.7150/thno.15616.

98. Moraga A, Gomez-Vallejo V, Cuartero MI, Szczupak B, San Sebastian E, Markuerkiaga I, et al. Imaging the role of toll-like receptor 4 on cell proliferation and inflammation after cerebral ischemia by positron emission tomography. $\mathrm{J}$ Cereb Blood Flow Metab. 2016;36(4):702-8. https://doi.org/10.1177/ $0271678 X 15627657$.

99. Joya A, Ardaya M, Montilla A, Garbizu M, Plaza-Garcia S, Gomez-Vallejo V, et al. In vivo multimodal imaging of adenosine A1 receptors in neuroinflammation after experimental stroke. Theranostics. 2021;11(1):410-25. https://doi.org/10.7150/thno. 51046.

100. Braun R, Klein R, Walter HL, Ohren M, Freudenmacher L, Getachew K, et al. Transcranial direct current stimulation accelerates recovery of function, induces neurogenesis and recruits oligodendrocyte precursors in a rat model of stroke. Exp Neurol. 2016;279:127-36. https://doi.org/10.1016/j.expneurol.2016.02. 018.

101. Tan C, Zhao S, Higashikawa K, Wang Z, Kawabori M, Abumiya $\mathrm{T}$, et al. [(18)F]DPA-714 PET imaging shows immunomodulatory effect of intravenous administration of bone marrow stromal cells after transient focal ischemia. EJNMMI Res. 2018;8(1):35. https:// doi.org/10.1186/s13550-018-0392-6.

102. Schmaljohann J, Minnerop M, Karwath P, Gundisch D, Falkai P, Guhlke S, et al. Imaging of central nAChReceptors with 2-[18F]FA 85380: optimized synthesis and in vitro evaluation in Alzheimer's disease. Appl Radiat Isot. 2004;61(6):1235-40. https://doi.org/10.1016/j.apradiso.2004.02.026.

103. Mittra ES, Koglin N, Mosci C, Kumar M, Hoehne A, Keu KV, et al. Pilot preclinical and clinical evaluation of (4S)-4-(3[18F]fluoropropyl)-L-glutamate (18F-FSPG) for PET/CT imaging of intracranial malignancies. PLoS One. 2016;11(2):e0148628. https://doi.org/10.1371/journal.pone.0148628.

104. Evens N, Vandeputte C, Coolen C, Janssen P, Sciot R, Baekelandt $\mathrm{V}$, et al. Preclinical evaluation of [11C]NE40, a type 2 cannabinoid receptor PET tracer. Nucl Med Biol. 2012;39(3):389-99. https://doi.org/10.1016/j.nucmedbio.2011.09.005.

105. Kumata K, Zhang Y, Fujinaga M, Ohkubo T, Mori W, Yamasaki T, et al. [(18)F]DAA1106: automated radiosynthesis using spirocyclic iodonium ylide and preclinical evaluation for positron emission tomography imaging of translocator protein (18kDa). Bioorg Med Chem. 2018;26(17):4817-22. https://doi.org/10. 1016/j.bmc.2018.08.017.

106. Wagner S, Faust A, Breyholz HJ, Schober O, Schafers M, Kopka K. The MMP inhibitor (R)-2-(N-benzyl-4-(2[18F]fluoroethoxy)phenylsulphonamido)-N-hydroxy-3methylbuta namide: Improved precursor synthesis and fully automated radiosynthesis. Appl Radiat Isot. 2011;69(6):862-8. https:// doi.org/10.1016/j.apradiso.2011.02.038.

107. Bauer A, Holschbach MH, Cremer M, Weber S, Boy C, Shah NJ, et al. Evaluation of 18F-CPFPX, a novel adenosine A1 receptor ligand: in vitro autoradiography and high-resolution small animal PET. J Nucl Med. 2003;44(10):1682-9.

108. Brugg B, Dubreuil YL, Huber G, Wollman EE, DelhayeBouchaud N, Mariani J. Inflammatory processes induce betaamyloid precursor protein changes in mouse brain. Proc Natl Acad Sci U S A. 1995;92(7):3032-5. https://doi.org/10.1073/ pnas.92.7.3032.

109. Johnston H, Boutin H, Allan SM. Assessing the contribution of inflammation in models of Alzheimer's disease. Biochem Soc Trans. 2011;39(4):886-90. https://doi.org/10.1042/BST0390886.

110. Verkhratsky A, Parpura V, Rodriguez-Arellano JJ, Zorec R. Astroglia in Alzheimer's Disease. Adv Exp Med Biol. 2019;1175:273-324. https://doi.org/10.1007/978-981-13-99138 11. 
111. Rodriguez JJ, Butt AM, Gardenal E, Parpura V, Verkhratsky A. Complex and differential glial responses in Alzheimer's disease and ageing. Curr Alzheimer Res. 2016;13(4):343-58. https://doi. org/10.2174/1567205013666160229112911.

112. Dahm R. Alzheimer's discovery. Curr Biol. 2006;16(21):R90610. https://doi.org/10.1016/j.cub.2006.09.056.

113. Chaney A, Williams SR, Boutin H. In vivo molecular imaging of neuroinflammation in Alzheimer's disease. J Neurochem. 2019;149(4):438-51. https://doi.org/10.1111/jnc.14615.

114. Lopez-Picon FR, Snellman A, Eskola O, Helin S, Solin O, Haaparanta-Solin M, et al. Neuroinflammation appears early on PET imaging and then plateaus in a mouse model of Alzheimer disease. J Nucl Med. 2018;59(3):509-15. https://doi.org/10.2967/ jnumed.117.197608.

115. Keller T, Lopez-Picon FR, Krzyczmonik A, Forsback S, Takkinen JS, Rajander J, et al. Comparison of high and low molar activity TSPO tracer [(18)F]F-DPA in a mouse model of Alzheimer's disease. J Cereb Blood Flow Metab. 2020;40(5):1012-20. https://doi. org/10.1177/0271678X19853117.

116. Sacher C, Blume T, Beyer L, Peters F, Eckenweber F, Sgobio C, et al. Longitudinal PET monitoring of amyloidosis and microglial activation in a second-generation amyloid-beta mouse model. $\mathrm{J}$ Nucl Med. 2019;60(12):1787-93. https://doi.org/10.2967/ jnumed.119.227322.

117. Biechele G, Wind K, Blume T, Sacher C, Beyer L, Eckenweber F, et al. Microglial activation in the right amygdala-entorhinalhippocampal complex is associated with preserved spatial learning in App(NL-G-F) mice. Neuroimage. 2020;117707. https://doi.org/ 10.1016/j.neuroimage.2020.117707.

118. Serriere S, Tauber C, Vercouillie J, Mothes C, Pruckner C, Guilloteau D, et al. Amyloid load and translocator protein $18 \mathrm{kDa}$ in APPswePS1-dE9 mice: a longitudinal study. Neurobiol Aging. 2015;36(4):1639-52. https://doi.org/10.1016/j. neurobiolaging.2014.11.023.

119. Chaney A, Bauer M, Bochicchio D, Smigova A, Kassiou M, Davies KE, et al. Longitudinal investigation of neuroinflammation and metabolite profiles in the APPswe xPS1Deltae9 transgenic mouse model of Alzheimer's disease. J Neurochem. 2018;144(3):318-35. https://doi.org/10.1111/jnc.14251.

120. Hu W, Pan D, Wang Y, Bao W, Zuo C, Guan Y, et al. PET imaging for dynamically monitoring neuroinflammation in APP/ PS1 mouse model using [(18)F]DPA714. Front Neurosci. 2020;14:810. https://doi.org/10.3389/fnins.2020.00810.

121. Levit A, Regis AM, Gibson A, Hough OH, Maheshwari S, Agca $\mathrm{Y}$, et al. Impaired behavioural flexibility related to white matter microgliosis in the TgAPP21 rat model of Alzheimer disease. Brain Behav Immun. 2019;80:25-34. https://doi.org/10.1016/j. bbi.2019.02.013.

122. Weishaupt N, Liu Q, Shin S, Singh R, Agca Y, Agca C, et al. APP21 transgenic rats develop age-dependent cognitive impairment and microglia accumulation within white matter tracts. $\mathrm{J}$ Neuroinflammation. 2018;15(1):241. https://doi.org/10.1186/ s12974-018-1273-7.

123. Yamagishi S, Iga Y, Nakamura M, Takizawa C, Fukumoto D, Kakiuchi T, et al. Upregulation of cannabinoid receptor type 2, but not TSPO, in senescence-accelerated neuroinflammation in mice: a positron emission tomography study. J Neuroinflammation. 2019;16(1):208. https://doi.org/10.1186/ s12974-019-1604-3.

124. Tournier BB, Tsartsalis S, Rigaud D, Fossey C, Cailly T, Fabis F, et al. TSPO and amyloid deposits in sub-regions of the hippocampus in the 3xTgAD mouse model of Alzheimer's disease. Neurobiol Dis. 2019;121:95-105. https://doi.org/10.1016/j.nbd. 2018.09.022.

125. Liu B, Hinshaw RG, Le KX, Park MA, Wang S, Belanger AP, et al. Space-like (56)Fe irradiation manifests mild, early sex- specific behavioral and neuropathological changes in wildtype and Alzheimer's-like transgenic mice. Sci Rep. 2019;9(1):12118. https://doi.org/10.1038/s41598-019-48615-1.

126. Rowe CC, Ackerman U, Browne W, Mulligan R, Pike KL, O'Keefe G, et al. Imaging of amyloid beta in Alzheimer's disease with 18F-BAY94-9172, a novel PET tracer: proof of mechanism. Lancet Neurol. 2008;7(2):129-35. https://doi.org/10.1016/S14744422(08)70001-2.

127. Rominger A, Brendel M, Burgold S, Keppler K, Baumann K, Xiong $\mathrm{G}$, et al. Longitudinal assessment of cerebral betaamyloid deposition in mice overexpressing Swedish mutant beta-amyloid precursor protein using $18 \mathrm{~F}$-florbetaben PET. J Nucl Med. 2013;54(7):1127-34. https://doi.org/10.2967/jnumed. 112.114660 .

128. Saito T, Matsuba Y, Mihira N, Takano J, Nilsson P, Itohara S, et al. Single App knock-in mouse models of Alzheimer's disease. Nat Neurosci. 2014;17(5):661-3. https://doi.org/10.1038/nn. 3697.

129. Chen CJ, Bando K, Ashino H, Taguchi K, Shiraishi H, Shima K, et al. In vivo SPECT imaging of amyloid-beta deposition with radioiodinated imidazo[1,2-a]pyridine derivative DRM106 in a mouse model of Alzheimer's disease. J Nucl Med. 2015;56(1): 120-6. https://doi.org/10.2967/jnumed.114.146944.

130. McGeer PL, Itagaki S, Boyes BE, McGeer EG. Reactive microglia are positive for HLA-DR in the substantia nigra of Parkinson's and Alzheimer's disease brains. Neurology. 1988;38(8):1285-91. https://doi.org/10.1212/wnl.38.8.1285.

131. Tansey MG, Goldberg MS. Neuroinflammation in Parkinson's disease: its role in neuronal death and implications for therapeutic intervention. Neurobiol Dis. 2010;37(3):510-8. https://doi.org/10. 1016/j.nbd.2009.11.004.

132. Cabezudo D, Baekelandt V, Lobbestael E. Multiple-hit hypothesis in Parkinson's disease: LRRK2 and inflammation. Front Neurosci. 2020;14:376. https://doi.org/10.3389/fnins.2020.00376.

133. de Lau LM, Breteler MM. Epidemiology of Parkinson's disease. Lancet Neurol. 2006;5(6):525-35. https://doi.org/10.1016/S14744422(06)70471-9.

134. Glass CK, Saijo K, Winner B, Marchetto MC, Gage FH. Mechanisms underlying inflammation in neurodegeneration. Cell. 2010;140(6):918-34. https://doi.org/10.1016/j.cell.2010. 02.016 .

135. Hatano K, Sekimata K, Yamada T, Abe J, Ito K, Ogawa M, et al. Radiosynthesis and in vivo evaluation of two imidazopyridineacetamides, [(11)C]CB184 and [ (11)C]CB190, as a PET tracer for $18 \mathrm{kDa}$ translocator protein: direct comparison with [ (11)C](R)-PK11195. Ann Nucl Med. 2015;29(4):325-35. https://doi.org/10.1007/s12149-015-0948-8.

136. Rodriguez-Chinchilla T, Quiroga-Varela A, Molinet-Dronda F, Belloso-Iguerategui A, Merino-Galan L, Jimenez-Urbieta H, et al. [(18)F]-DPA-714 PET as a specific in vivo marker of early microglial activation in a rat model of progressive dopaminergic degeneration. Eur J Nucl Med Mol Imaging. 2020;47(11):260212. https://doi.org/10.1007/s00259-020-04772-4.

137. Wu CY, Chen YY, Lin JJ, Li JP, Chen JK, Hsieh TC, et al. Development of a novel radioligand for imaging $18-\mathrm{kD}$ translocator protein (TSPO) in a rat model of Parkinson's disease. BMC Med Imaging. 2019;19(1):78. https://doi.org/10.1186/ s12880-019-0375-8.

138. Chen MK, Kuwabara H, Zhou Y, Adams RJ, Brasic JR, McGlothan JL, et al. VMAT2 and dopamine neuron loss in a primate model of Parkinson's disease. J Neurochem. 2008;105(1):78-90. https://doi.org/10.1111/j.1471-4159.2007. 05108.x.

139. Crabbe M, Van der Perren A, Bollaerts I, Kounelis S, Baekelandt $\mathrm{V}$, Bormans $\mathrm{G}$, et al. Increased P2X7 receptor binding is associated with neuroinflammation in acute but not chronic rodent 
models for Parkinson's disease. Front Neurosci. 2019;13:799. https://doi.org/10.3389/fnins.2019.00799.

140. Maia S, Arlicot N, Vierron E, Bodard S, Vergote J, Guilloteau D, et al. Longitudinal and parallel monitoring of neuroinflammation and neurodegeneration in a 6-hydroxydopamine rat model of Parkinson's disease. Synapse (New York, NY). 2012;66(7):57383. https://doi.org/10.1002/syn.21543.

141. Vetel S, Serriere S, Vercouillie J, Vergote J, Chicheri G, Deloye JB, et al. Extensive exploration of a novel rat model of Parkinson's disease using partial 6-hydroxydopamine lesion of dopaminergic neurons suggests new therapeutic approaches. Synapse (New York, NY). 2019;73(3):e22077. https://doi.org/10.1002/syn. 22077.

142. Belloli S, Morari M, Murtaj V, Valtorta S, Moresco RM, Gilardi MC. Translation imaging in Parkinson's disease: focus on neuroinflammation. Front Aging Neurosci. 2020;12:152. https://doi. org/10.3389/fnagi.2020.00152.

143. Walsh S, Finn DP, Dowd E. Time-course of nigrostriatal neurodegeneration and neuroinflammation in the 6-hydroxydopamineinduced axonal and terminal lesion models of Parkinson's disease in the rat. Neuroscience. 2011;175:251-61. https://doi.org/10. 1016/j.neuroscience.2010.12.005.

144. Cicchetti F, Brownell AL, Williams K, Chen YI, Livni E, Isacson O. Neuroinflammation of the nigrostriatal pathway during progressive 6-OHDA dopamine degeneration in rats monitored by immunohistochemistry and PET imaging. Eur J Neurosci. 2002;15(6):991-8. https://doi.org/10.1046/j.1460-9568.2002. 01938.x.

145. Fricke IB, Viel T, Worlitzer MM, Collmann FM, Vrachimis A, Faust A, et al. 6-hydroxydopamine-induced Parkinson's diseaselike degeneration generates acute microgliosis and astrogliosis in the nigrostriatal system but no bioluminescence imagingdetectable alteration in adult neurogenesis. Eur J Neurosci. 2016;43(10):1352-65. https://doi.org/10.1111/ejn.13232.

146. Nomura M, Toyama H, Suzuki H, Yamada T, Hatano K, Wilson AA, et al. Peripheral benzodiazepine receptor $/ 18 \mathrm{kDa}$ translocator protein positron emission tomography imaging in a rat model of acute brain injury. Ann Nucl Med. 2021;35(1):8-16. https://doi. org/10.1007/s12149-020-01530-2.

147. Cumming P, Pedersen MD, Minuzzi L, Mezzomo K, Danielsen EH, Iversen P, et al. Distribution of PK11195 binding sites in porcine brain studied by autoradiography in vitro and by positron emission tomography. Synapse (New York, NY). 2006;59(7): 418-26. https://doi.org/10.1002/syn.20257.

148. Joers V, Masilamoni G, Kempf D, Weiss AR, Rotterman TM, Murray B, et al. Microglia, inflammation and gut microbiota responses in a progressive monkey model of Parkinson's disease: A case series. Neurobiol Dis. 2020;144:105027. https://doi.org/10. 1016/j.nbd.2020.105027.

149. Belloli S, Pannese M, Buonsanti C, Maiorino C, Di Grigoli G, Carpinelli A, et al. Early upregulation of $18-\mathrm{kDa}$ translocator protein in response to acute neurodegenerative damage in TREM2deficient mice. Neurobiol Aging. 2017;53:159-68. https://oi.org/ 10.1016/j.neurobiolaging.2017.01.010.

150. Lillethorup TP, Glud AN, Alstrup AKO, Mikkelsen TW, Nielsen $\mathrm{EH}$, Zaer H, et al. Nigrostriatal proteasome inhibition impairs dopamine neurotransmission and motor function in minipigs. Exp Neurol. 2018;303:142-52. https://doi.org/10.1016/j.expneurol. 2018.02.005.

151. Lillethorup TP, Glud AN, Alstrup AKO, Noer O, Nielsen EHT, Schacht AC, et al. Longitudinal monoaminergic PET imaging of chronic proteasome inhibition in minipigs. Sci Rep. 2018;8(1): 15715. https://doi.org/10.1038/s41598-018-34084-5.

152. Crabbe M, Van der Perren A, Kounelis S, Lavreys T, Bormans G, Baekelandt $\mathrm{V}$, et al. Temporal changes in neuroinflammation and brain glucose metabolism in a rat model of viral vector-induced alpha-synucleinopathy. Exp Neurol. 2019;320:112964. https:// doi.org/10.1016/j.expneurol.2019.112964.

153. Lillethorup TP, Glud AN, Landeck N, Alstrup AKO, Jakobsen S, Vang $\mathrm{K}$, et al. In vivo quantification of glial activation in minipigs overexpressing human alpha-synuclein. Synapse (New York, NY). 2018;72(12):e22060. https://doi.org/10.1002/syn.22060.

154. Walker MD, Dinelle K, Kornelsen R, Lee NV, Miao Q, Adam M, et al. [11C]PBR28 PET imaging is sensitive to neuroinflammation in the aged rat. J Cereb Blood Flow Metab. 2015;35(8):1331-8. https://doi.org/10.1038/jcbfm.2015.54.

155. Shivers KY, Nikolopoulou A, Machlovi SI, Vallabhajosula S, Figueiredo-Pereira ME. PACAP27 prevents Parkinson-like neuronal loss and motor deficits but not microglia activation induced by prostaglandin J2. Biochim Biophys Acta. 2014;1842(9):170719. https://doi.org/10.1016/j.bbadis.2014.06.020.

156. Ghosh R, Tabrizi SJ. Clinical features of Huntington's disease. Adv Exp Med Biol. 2018;1049:1-28. https://doi.org/10.1007/ 978-3-319-71779-1_1.

157. Tai YF, Pavese N, Gerhard A, Tabrizi SJ, Barker RA, Brooks DJ, et al. Microglial activation in presymptomatic Huntington's disease gene carriers. Brain. 2007;130(Pt 7):1759-66. https://doi.org/ 10.1093/brain/awm044.

158. Singhrao SK, Neal JW, Morgan BP, Gasque P. Increased complement biosynthesis by microglia and complement activation on neurons in Huntington's disease. Exp Neurol. 1999;159(2):36276. https://doi.org/10.1006/exnr.1999.7170.

159. Dalrymple A, Wild EJ, Joubert R, Sathasivam K, Bjorkqvist M, Petersen A, et al. Proteomic profiling of plasma in Huntington's disease reveals neuroinflammatory activation and biomarker candidates. J Proteome Res. 2007;6(7):2833-40. https://doi.org/10. 1021/pr0700753.

160. Pouladi MA, Morton AJ, Hayden MR. Choosing an animal model for the study of Huntington's disease. Nat Rev Neurosci. 2013;14(10):708-21. https://doi.org/10.1038/nrn3570.

161. DiFiglia M. Excitotoxic injury of the neostriatum: a model for Huntington's disease. Trends Neurosci. 1990;13(7):286-9. https://doi.org/10.1016/0166-2236(90)90111-m.

162. Shear DA, Dong J, Gundy CD, Haik-Creguer KL, Dunbar GL. Comparison of intrastriatal injections of quinolinic acid and 3nitropropionic acid for use in animal models of Huntington's disease. Prog Neuro-Psychopharmacol Biol Psychiatry. 1998;22(7): 1217-40. https://doi.org/10.1016/s0278-5846(98)00070-0.

163. Brouillet E, Jacquard C, Bizat N, Blum D. 3-Nitropropionic acid: a mitochondrial toxin to uncover physiopathological mechanisms underlying striatal degeneration in Huntington's disease. J Neurochem. 2005;95(6):1521-40. https://doi.org/10.1111/j. 1471-4159.2005.03515.x.

164. Ferrante RJ, Kowall NW, Cipolloni PB, Storey E, Beal MF. Excitotoxin lesions in primates as a model for Huntington's disease: histopathologic and neurochemical characterization. Exp Neurol. 1993;119(1):46-71. https://doi.org/10.1006/exnr.1993. 1006.

165. Hantraye P, Riche D, Maziere M, Isacson O. A primate model of Huntington's disease: behavioral and anatomical studies of unilateral excitotoxic lesions of the caudate-putamen in the baboon. Exp Neurol. 1990;108(2):91-104. https://doi.org/10.1016/00144886(90)90014-j.

166. Brouillet E, Conde F, Beal MF, Hantraye P. Replicating Huntington's disease phenotype in experimental animals. Prog Neurobiol. 1999;59(5):427-68. https://doi.org/10.1016/s03010082(99)00005-2.

167. Beal MF, Kowall NW, Ellison DW, Mazurek MF, Swartz KJ, Martin JB. Replication of the neurochemical characteristics of Huntington's disease by quinolinic acid. Nature. 1986;321(6066):168-71. https://doi.org/10.1038/321168a0. 
168. Arlicot N, Katsifis A, Garreau L, Mattner F, Vergote J, Duval S, et al. Evaluation of CLINDE as potent translocator protein (18 $\mathrm{kDa}$ SPECT radiotracer reflecting the degree of neuroinflammation in a rat model of microglial activation. Eur J Nucl Med Mol Imaging. 2008. https://doi.org/10.1007/s00259-008-0834-x.

169. Beal MF, Ferrante RJ, Swartz KJ, Kowall NW. Chronic quinolinic acid lesions in rats closely resemble Huntington's disease. J Neurosci. 1991;11(6):1649-59.

170. Ramachandran S, Thangarajan S. Thymoquinone loaded solid lipid nanoparticles counteracts 3-nitropropionic acid induced motor impairments and neuroinflammation in rat model of Huntington's disease. Metab Brain Dis. 2018;33(5):1459-70. https://doi.org/10. 1007/s11011-018-0252-0.

171. Lavisse S, Inoue K, Jan C, Peyronneau MA, Petit F, Goutal S, et al. [18F]DPA-714 PET imaging of translocator protein TSPO $(18 \mathrm{kDa})$ in the normal and excitotoxically-lesioned nonhuman primate brain. Eur J Nucl Med Mol Imaging. 2015;42(3):47894. https://doi.org/10.1007/s00259-014-2962-9.

172. Arlicot N, Tronel C, Bodard S, Garreau L, de la Crompe B, Vandevelde I, et al. Translocator protein ( $18 \mathrm{kDa})$ mapping with [125I]-CLINDE in the quinolinic acid rat model of excitotoxicity: a longitudinal comparison with microglial activation, astrogliosis, and neuronal death. Mol Imaging. 2014;13:4-11.

173. Levivier M, Holemans S, Togasaki DM, Maloteaux JM, Brotchi J, Przedborski S. Quantitative assessment of quinolinic acid-induced striatal toxicity in rats using radioligand binding assays. Neurol Res. 1994;16(3):194-200. https://doi.org/10.1080/01616412. 1994.11740226.

174. Leaver KR, Reynolds A, Bodard S, Guilloteau D, Chalon S, Kassiou M. Effects of translocator protein (18 kDa) ligands on microglial activation and neuronal death in the quinolinic-acidinjected rat striatum. ACS Chem Neurosci. 2012;3(2):114-9. https://doi.org/10.1021/cn200099e.

175. Ryu JK, Choi HB, McLarnon JG. Peripheral benzodiazepine receptor ligand PK11195 reduces microglial activation and neuronal death in quinolinic acid-injected rat striatum. Neurobiol Dis. 2005;20(2):550-61. https://doi.org/10.1016/j.nbd.2005.04.010.

176. Moresco RM, Lavazza T, Belloli S, Lecchi M, Pezzola A, Todde $\mathrm{S}$, et al. Quinolinic acid induced neurodegeneration in the striatum: a combined in vivo and in vitro analysis of receptor changes and microglia activation. Eur J Nucl Med Mol Imaging. 2008;35(4): 704-15. https://doi.org/10.1007/s00259-007-0651-7.

177. Rojas S, Martin A, Arranz MJ, Pareto D, Purroy J, Verdaguer E, et al. Imaging brain inflammation with [(11)C]PK11195 by PET and induction of the peripheral-type benzodiazepine receptor after transient focal ischemia in rats. J Cereb Blood Flow Metab. 2007;27(12):1975-86. https://doi.org/10.1038/sj.jcbfm.9600500.

178. Dusart I, Marty S, Peschanski M. Glial changes following an excitotoxic lesion in the CNS-II. Astrocytes. Neuroscience. 1991;45(3):541-9. https://doi.org/10.1016/0306-4522(91)90269-t.

179. Lavisse S, Guillermier M, Herard AS, Petit F, Delahaye M, Van Camp N, et al. Reactive astrocytes overexpress TSPO and are detected by TSPO positron emission tomography imaging. J Neurosci. 2012;32(32):10809-18. https://doi.org/10.1523/ JNEUROSCI.1487-12.2012.

180. Escartin C, Guillemaud O, Carrillo-de Sauvage MA. Questions and (some) answers on reactive astrocytes. Glia. 2019;67(12): 2221-47. https://doi.org/10.1002/glia.23687.

181. Chang R, Liu X, Li S, Li XJ. Transgenic animal models for study of the pathogenesis of Huntington's disease and therapy. Drug Des Devel Ther. 2015;9:2179-88. https://doi.org/10.2147/DDDT. S58470.

182. Davies SW, Turmaine M, Cozens BA, DiFiglia M, Sharp AH, Ross CA, et al. Formation of neuronal intranuclear inclusions underlies the neurological dysfunction in mice transgenic for the
HD mutation. Cell. 1997;90(3):537-48. https://doi.org/10.1016/ s0092-8674(00)80513-9.

183. Mangiarini L, Sathasivam K, Seller M, Cozens B, Harper A, Hetherington $\mathrm{C}$, et al. Exon 1 of the HD gene with an expanded CAG repeat is sufficient to cause a progressive neurological phenotype in transgenic mice. Cell. 1996;87(3):493-506. https://doi. org/10.1016/s0092-8674(00)81369-0.

184. Luthi-Carter R, Hanson SA, Strand AD, Bergstrom DA, Chun W, Peters NL, et al. Dysregulation of gene expression in the R6/2 model of polyglutamine disease: parallel changes in muscle and brain. Hum Mol Genet. 2002;11(17):1911-26. https://doi.org/10. 1093/hmg/11.17.1911.

185. Hsiao HY, Chiu FL, Chen CM, Wu YR, Chen HM, Chen YC, et al. Inhibition of soluble tumor necrosis factor is therapeutic in Huntington's disease. Hum Mol Genet. 2014;23(16):4328-44. https://doi.org/10.1093/hmg/ddu151.

186. Simmons DA, Casale M, Alcon B, Pham N, Narayan N, Lynch G. Ferritin accumulation in dystrophic microglia is an early event in the development of Huntington's disease. Glia. 2007;55(10): 1074-84. https://doi.org/10.1002/glia.20526.

187. Simmons DA, James ML, Belichenko NP, Semaan S, Condon C, Kuan J, et al. TSPO-PET imaging using [18F]PBR06 is a potential translatable biomarker for treatment response in Huntington's disease: preclinical evidence with the p75NTR ligand LM11A-31. Hum Mol Genet. 2018;27(16):2893-912. https://doi.org/10. 1093/hmg/ddy202.

188. Mattner F, Staykova M, Berghofer P, Wong HJ, Fordham S, Callaghan $\mathrm{P}$, et al. Central nervous system expression and PET imaging of the translocator protein in relapsing-remitting experimental autoimmune encephalomyelitis. J Nucl Med. 2013;54(2): 291-8. https://doi.org/10.2967/jnumed.112.108894.

189. Belloli S, Zanotti L, Murtaj V, Mazzon C, Di Grigoli G, Monterisi $\mathrm{C}$, et al. (18)F-VC701-PET and MRI in the in vivo neuroinflammation assessment of a mouse model of multiple sclerosis. $\mathrm{J}$ Neuroinflammation. 2018;15(1):33. https://doi.org/10.1186/ s12974-017-1044-x.

190. Nack A, Brendel M, Nedelcu J, Daerr M, Nyamoya S, Beyer C et al. Expression of Translocator protein and [18F]-GE180 ligand uptake in multiple sclerosis animal models. Cells. 2019;8(2). doi: https://doi.org/10.3390/cells8020094.

191. Vainio SK, Dickens AM, Tuisku J, Eskola O, Solin O, Loyttyniemi E, et al. Cessation of anti-VLA-4 therapy in a focal rat model of multiple sclerosis causes an increase in neuroinflammation. EJNMMI Res. 2019;9(1):38. https://doi.org/10.1186/ s13550-019-0508-7.

192. Nedelcu J, Reinbach C, Riedler P, Brendel M, Rominger A, Kaye $\mathrm{J}$, et al. Laquinimod ameliorates secondary brain inflammation. Neurobiol Dis. 2020;134:104675. https://doi.org/10.1016/j.nbd. 2019.104675.

193. Zinnhardt B, Belloy M, Fricke IB, Orije J, Guglielmetti C, Hermann $\mathrm{S}$, et al. Molecular imaging of immune cell dynamics during de- and remyelination in the cuprizone model of multiple sclerosis by [(18)F]DPA-714 PET and MRI. Theranostics. 2019;9(6):1523-37. https://doi.org/10.7150/thno.32461.

194. Coda AR, Anzilotti S, Boscia F, Greco A, Panico M, Gargiulo S, et al. In vivo imaging of CNS microglial activation/macrophage infiltration with combined [(18)F]DPA-714-PET and SPIO-MRI in a mouse model of relapsing remitting experimental autoimmune encephalomyelitis. Eur J Nucl Med Mol Imaging. 2021;48(1):40 52. https://doi.org/10.1007/s00259-020-04842-7.

195. Converse AK, Larsen EC, Engle JW, Barnhart TE, Nickles RJ, Duncan ID. 11C-(R)-PK11195 PET imaging of microglial activation and response to minocycline in zymosan-treated rats. J Nucl Med. 2011;52(2):257-62. https://doi.org/10.2967/jnumed.110. 082743. 
196. Bruck W, Pfortner R, Pham T, Zhang J, Hayardeny L, Piryatinsky $\mathrm{V}$, et al. Reduced astrocytic NF-kappaB activation by laquinimod protects from cuprizone-induced demyelination. Acta Neuropathol. 2012;124(3):411-24. https://doi.org/10.1007/ s00401-012-1009-1.

197. Thone J, Ellrichmann G, Seubert S, Peruga I, Lee DH, Conrad R, et al. Modulation of autoimmune demyelination by laquinimod via induction of brain-derived neurotrophic factor. Am J Pathol. 2012;180(1):267-74. https://doi.org/10.1016/j.ajpath.2011.09. 037.

198. de Paula FD, de Vries EF, Sijbesma JW, Buchpiguel CA, Dierckx RA, Copray SC. PET imaging of glucose metabolism, neuroinflammation and demyelination in the lysolecithin rat model for multiple sclerosis. Mult Scler. 2014;20(11):1443-52. https://doi. org/10.1177/1352458514526941.

199. Martin A, Vazquez-Villoldo N, Gomez-Vallejo V, Padro D, Soria FN, Szczupak B, et al. In vivo imaging of system xc- as a novel approach to monitor multiple sclerosis. Eur J Nucl Med Mol Imaging. 2016;43(6):1124-38. https://doi.org/10.1007/s00259015-3275-3.
200. Wu C, Wang C, Popescu DC, Zhu W, Somoza EA, Zhu J, et al. A novel PET marker for in vivo quantification of myelination. Bioorg Med Chem. 2010;18(24):8592-9. https://doi.org/10. 1016/j.bmc.2010.10.018.

201. Chen Q, Meng X, McQuade P, Rubins D, Lin SA, Zeng Z, et al. Synthesis and preclinical evaluation of folate-NOTA-Al(18)F for PET Imaging of folate-receptor-positive tumors. Mol Pharm. 2016;13(5):1520-7. https://doi.org/10.1021/acs.molpharmaceut. 5 b00989.

202. Elo P, Li XG, Liljenback H, Helin S, Teuho J, Koskensalo K, et al. Folate receptor-targeted positron emission tomography of experimental autoimmune encephalomyelitis in rats. J Neuroinflammation. 2019;16(1):252. https://doi.org/10.1186/ s12974-019-1612-3.

Publisher's note Springer Nature remains neutral with regard to jurisdictional claims in published maps and institutional affiliations. 